\title{
Impact of Aging on Steroid Hormone Biosynthesis and Secretion
}

\author{
Syed Kashif Zaidi, Wen-Jun Shen and Salman Azhar*
}

Geriatric Research, Education and Clinical Center (GRECC), VA Palo Health Care System, Palo Alto, CA and Division

of Gastroenterology and Hepatology, Department of Medicine, Stanford University, Stanford, CA, USA

\begin{abstract}
Steroid hormones are lipophilic, low-molecular weight organic compounds all of which are derived from cholesterol. They are primarily synthesized by steroidogenic glands such as gonads (ovary and testis), the adrenal gland and, during pregnancy, by the placental trophoblasts. Limited steroid synthesis also takes place in the brain. Steroid hormones are crucial for the proper functioning of the body. They mediate a wide variety of vital physiological functions, ranging from maintaining normal reproductive function and secondary sexual characteristics, to regulating virtually every metabolic process in the body. Like many age-related endocrine disorders, aging also progressively impacts the tissue-specific synthesis and secretion of steroid hormones. The goal of this review is to summarize the effects of aging on steroid hormone synthesis and secretion by the adrenal gland and gonads of both human and experimental animal models, to describe the potential involvement of excessive oxidative stress in mediating age-related alterations in steroidogenesis, and to discuss the possible underlying mechanisms involved.
\end{abstract}

Keywords: Glucocorticoids, Mineralocorticoids, Androgens, Estrogens, Progestins, Gonadal Steroids, Cholesterol, Oxidative Stress, Cholesterol Transport Proteins, Antioxidants.

\section{INTRODUCTION}

The steroid hormones are lipophilic, low-molecular weight organic compounds all of which are derived from cholesterol [1-6]. They share a typical but not identical cyclopentano-perhydrophenanthrene nucleus (steroid nucleus) of cholesterol. They are mainly synthesized by steroidogenic glands such as gonads (ovary and testis), the adrenals and, during pregnancy, by the placental trophoblasts, and are then released into the bloodstream [1-7]. Based on their physiological functions, the steroid hormones are broadly classified into three categories: the glucocorticoids, mineralocorticoids and sex steroids (androgens and estrogens). The adrenal cortex produces mineralocorticoids (aldosterone, deoxycorticosterone), glucocorticoids (cortisol, corticosterone), and sex steroids (mainly the androgen precursors dehydroepiandrosterone [DHEA] and androstenedione); mineralocorticoids are mainly produced in the zona glomerulosa zone, whereas glucocorticoids are principally produced in the zona fasciculate of the adrenal cortex. The adrenal sex steroid (androgens) are mainly a product of the zona reticularis of the adrenal cortex [1-6,8].

Testosterone is a major androgen produced in the testis, and its primary site of synthesis is in Leydig cells [1-6,9]. The ovaries secrete three major sex steroids: estrogens, androgens and progestin [1-6,10]. The $17 \beta$-estradiol is the principal estrogen secreted by the ovarian theca cells. The ovary also secretes a variety of androgens including DHEA, androstenedione, testosterone, and dihydrotestosterone. They

*Address correspondence to this author at the GRECC-182B, VA Palo Alto Health Care System, 3801 Miranda Ave, Palo Alto, CA 94304-1290, USA; Tel: (650) 858-3933 or (650) 493-5000; X 65365; Fax: (650) 496-2505, (650) 849-0484; E-mails: salman.azhar@va.gov; sazhar@stanford.edu are produced by the theca cells and to a lesser degree by ovarian stroma cells. The major ovarian androgen, androstenedione is produced by the theca cells and transported to ovarian granulosa cells for estrogen production. Theca cells and to a lesser degree ovarian stroma cells also secrete a variety of other androgens including DHEA, testosterone, and dihydrotestosterone (DHT). The major progestins include pregnenolone, progesterone, and 17-hydroxyprogesterone. Among these, pregnenolone is produced by all steroidogenic tissues where it serves as a precursor for all steroid hormones (Fig. 1). Progesterone is the principal secretory product of the corpus luteum and is responsible for the implantation of the fertilized ovum and maintenance of pregnancy during the first 6-8 weeks of gestation, but during pregnancy the main source for progesterone is the placenta [7]. It can also be converted to estrogen or testosterone in extraglandular tissues.

Steroid hormones are vital to the smooth functioning of a number of physiological functions (Table 1). For example, female-sex steroids, estrogens and progestin are required for follicular development, ovulation, development, maturation and maintenance of secondary sex organs (female sexual determination), sexual behavior patterns, and also, for sustaining pregnancy when it occurs $[7,11,12]$. Estrogens also play an important role in cardiovascular physiology, bone integrity, neuronal growth and differentiation, neuroprotection, cognition, and behavior [13,14 and references therein]. Testosterone, the most prevalent male sex-hormone (androgen) and its biologically active form, DHT are necessary for normal spermatogenesis and development, maturation and function of secondary sex organs (male sexual determination) $[12,15]$. Beyond its reproductive function, testosterone is responsible for increased muscle mass, sexual function and libido, body hair and decreased risk of osteoporosis, and 


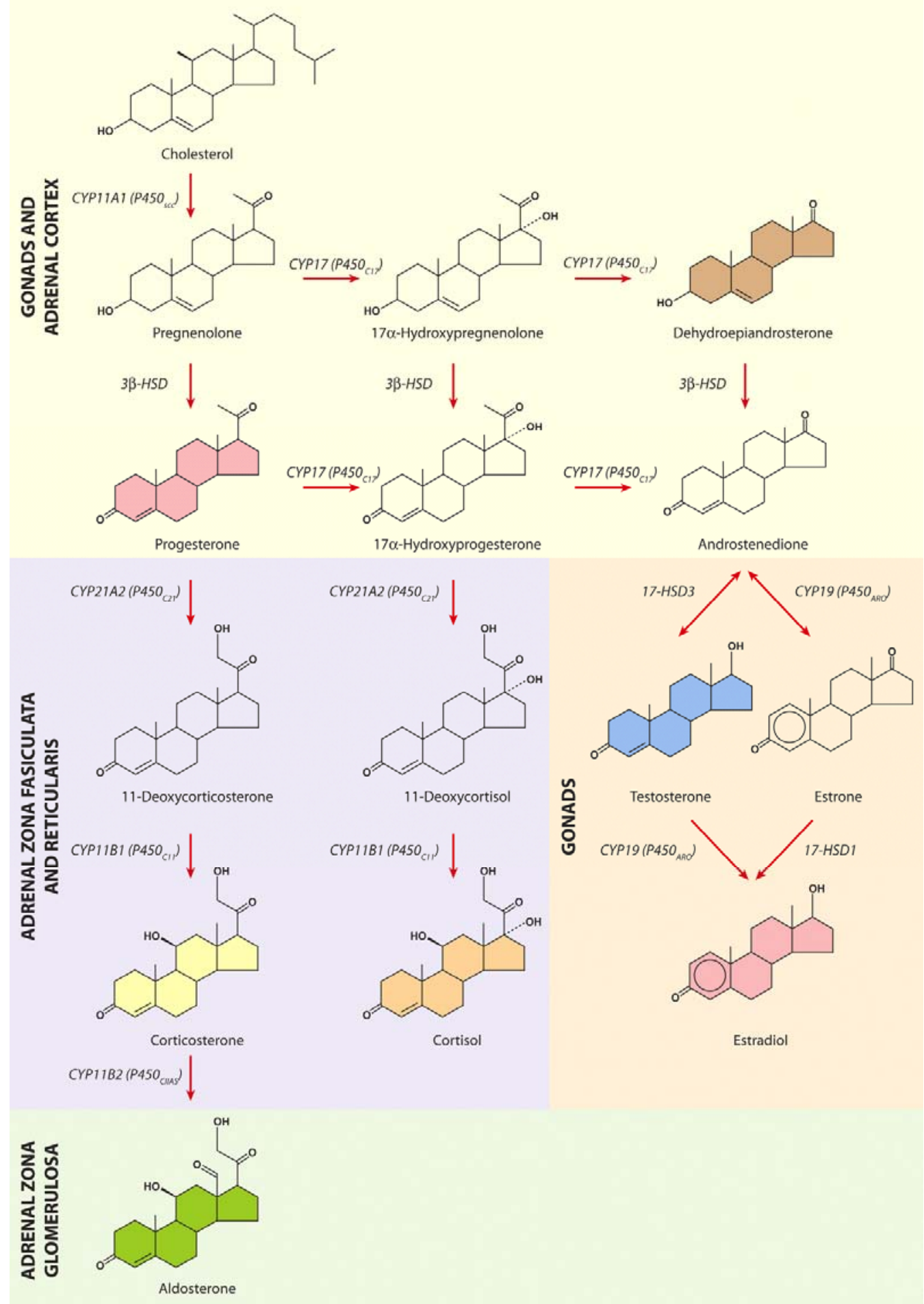

Fig. (1). Pathways of steroid biosynthesis in adrenal glands and gonads. Enzymatic reactions that are common to both adrenal and gonadal tissues, specific for adrenal (i.e., zona fasiculata and reticularis and zona glomerulosa) gland and gonadal tissues are shown shaded with different colors. Key enzymes are shown above the arrows indicating the specific enzymatic reactions. Modified from White [1], Conley and Bird [2], Payne and Hales [3] and Miller and Auchus [6].

also takes part in the nervous system [16,17]. Interestingly, a very recent study by Oury et al., [17a] suggests that osteocalcin, a hormone produced by bone-building cells (osteoblasts) may have a role in regulating male fertility. These investigators, in a series of experiments using mice engineered to generate only low levels of osteocalcin demon- strated that male mice had lowered fertility due to reduced testosterone production. This effect appears to be specific for testis since osteocalcin levels failed to influence ovarian estrogen production and no impact on the fertility of female mice. 
Table 1. Physiological Functions of the Major Steroid Hormones

\begin{tabular}{|c|c|}
\hline Steroid Hormone & Functions \\
\hline Progesterone (Progestin) & Prepares uterus lining for implantation of ovum and mammary glands for lactation \\
\hline Cortisol (Glucocorticoid) & $\begin{array}{l}\text { Helps control carbohydrate, protein and lipid metabolism; promotes gluconeogenesis; favors breakdown of fat } \\
\text { and protein (fuel mobilization); exerts anti-inflammatory actions; protects against stress; reduces immune re- } \\
\text { sponses; helps to maintain blood pressure through its hypertensive actions. }\end{array}$ \\
\hline Aldosterone (Mineralocorticoid) & $\begin{array}{l}\text { Helps to regulate body's water and electrolyte balance. Maintains blood volume and blood pressure by increas- } \\
\text { ing sodium reabsorption in exchange for } \mathrm{K}^{+} \text {and } \mathrm{H}^{+} \text {at electrolyte-transforming epithelia of the kidney. }\end{array}$ \\
\hline $\begin{array}{l}\text { Dehydroepiandrosterone (DHEA) and } \\
\text { Dehydroepiandrosterone sulfate } \\
\text { (DHEA-S) (Adrenal androgens) }\end{array}$ & $\begin{array}{l}\text { The sulfated form of DHEA, DHEA-S is suggested to affect a wide variety of physiological systems including } \\
\text { neurological, immune, aging and somatic growth and development. DHEA and DHEA-S are an important } \\
\text { source of testosterone and estrogen in peripheral tissues, contributing as much as } 50 \% \text { of total peripheral andro- } \\
\text { gens in men, } 75 \% \text { of peripheral estrogen in premenopausal women, and } 100 \% \text { of peripheral estrogen in post- } \\
\text { menopausal women. }\end{array}$ \\
\hline Testosterone (Androgen) & $\begin{array}{l}\text { Controls the development of male secondary sex characteristics; regulates sperm production; promotes increased } \\
\text { muscle mass through increased protein formation; prevents bone resorption }\end{array}$ \\
\hline $\begin{array}{l}\text { Estradiol } \\
\text { (Estrogen) }\end{array}$ & $\begin{array}{l}\text { Controls the development of female secondary sex characteristics; regulates menstrual cycle; contributes to the } \\
\text { hormonal regulation of pregnancy and lactation; prevents bone resorption }\end{array}$ \\
\hline
\end{tabular}

The adrenal mineralocorticoid, aldosterone, maintains salt and water balance, and hence blood pressure [18], while the adrenal glucocorticoid, cortisol (corticosterone in rodents), is essential for diverse biological functions including regulation of carbohydrate, protein, and lipid metabolism in a manner nearly opposite to that of insulin, stress adaptation, inflammatory reactions, the immune system and stress adaptation [19]. The functional roles of adrenal androgens are not well understood, but considerable evidence now indicates that they are involved in the regulation of bone mineral density, muscle mass, well-being, and libido, as well as beneficial effects against skin atrophy, type 2 diabetes, and obesity [20].

Like many age-related endocrine disorders, aging also progressively impacts the tissue-specific synthesis and secretion of steroid hormones [21-24]. The goal of this review is to summarize the effects of aging on steroid hormone synthesis and secretion by the adrenal gland and gonads of both human and experimental animal models, describe the potential involvement of excessive oxidative stress in mediating age-related alterations in steroidogenesis, and discuss the possible underlying mechanisms involved.

\section{STEROIDOGENESIS: AN OVERVIEW}

Although the focus of this review is the age-related alternations in steroid hormone synthesis and secretion in the adrenal gland and gonads, in order to familiarize the readers about the subject, first, a brief overview regarding the critical events involved in steroid hormone biosynthesis is presented.

\section{Source of Cholesterol}

\section{Substrate}

Cholesterol is an obligate intermediate in the synthesis of all of the steroids produced by the adrenal, ovary, testis and placenta. Cholesterol can be obtained from three principal sources: a) cholesterol synthesized de novo from the acetate; b) cholesterol derived from the circulating lipoproteins; and c) cholesterol recruited by the hydrolysis of cytoplasmic cholesteryl esters stored in the form of lipid droplets (Fig. 2) $[25,26]$. In some cultured cells including steroidogenic cells, cholesterol can also be obtained from the plasma membrane [27-29].

\section{Low-density Lipoprotein (LDL) Receptor (LDL-R)- mediated Endocytic Uptake of Apolipoprotein B (apoB) or Apoe containing Plasma}

\section{Lipoproteins}

The principal source of cholesterol utilized by the human adrenal and ovary is provided from the circulation in the form of low-density lipoprotein (LDL)-cholesterol. The first step in acquiring LDL-cholesterol is the binding of apolipoprotein B-100 (apoB) cholesterol-rich LDL particles to the cell surface of LDL receptors [30]. LDL is then internalized via the receptor-mediated endocytosis, and a drop in the $\mathrm{pH}$ (from $\sim 7.0$ to $\sim 5.0$ ) causes the LDL to separate from its receptor. The vesicle then pinches apart into two smaller vesicles: one containing free LDLs; the other containing nowempty receptors. The vesicles with LDL particles fuse with lysosomes and free cholesterol produced following hydrolysis by enzymes of the lysosome which is released into the 


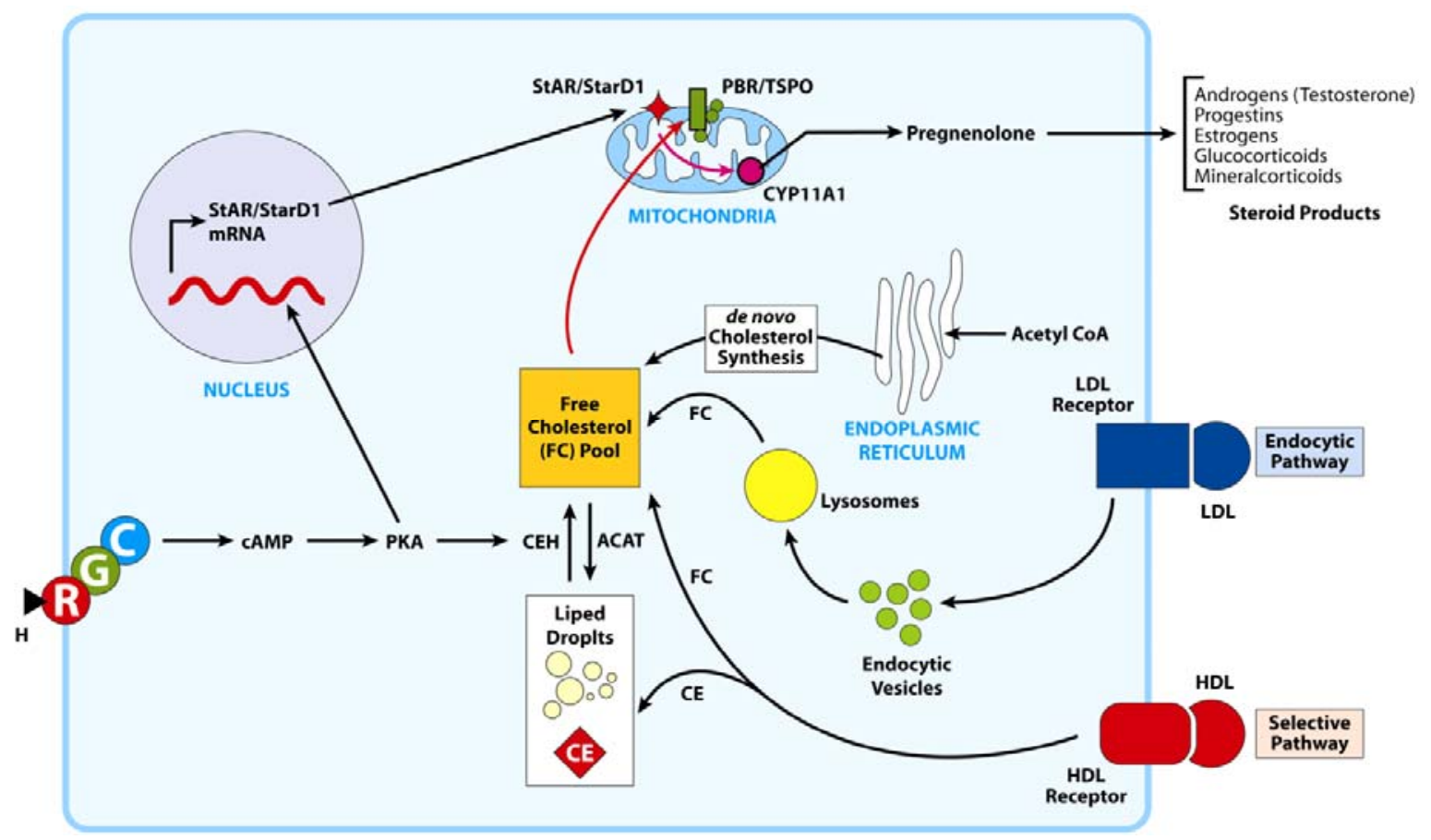

Fig. (2). Cholesterol metabolism for the biosynthesis of adrenal and gonadal steroids. LDL cholesteryl esters (CEs) or apoE containing HDL (apoE-HDL) CEs can be internalized via the LDL-receptor (LDL-R)-mediated endocytic pathway, whereas LDL and HDL CEs can be 'selectively' delivered into the cell via the scavenger receptor class B, type I (SR-BI)-mediated selective patrhway. CEs delivered by LDL-Rendocytic are hydrolyzed to free (unsterified) cholesterol (FC), whereas selectively delivered CEs are hydrolyzed by neutral cholesteryl ester hydrolase (CEH) (hormone-sensitive lipase, HSL). FC can also be derived from the the stored CEs in the form of lipid droplets through the actions of CEH or via the de novo synthesis from the acetyl CoA. The newly acquired FC is transported into mitochondria via combined actions of steroidogenic acute regulatory protein (StAR/StarD1) peripheral-type benzodiazepine receptor/transporter protein (PBR/TSPO) for metabolism by cholesterol side-chain cleavage enzyme (P450scc/CYP11A1). Any excess FC cholesterol is esterified for storage by acetyl CoA: cholesterol acyltransferase (ACAT). C, adenylate cuclase; G, G proteins (guanine nucleotide-binding proteins); H, tropic hormones, ACTH, FSH and LH/hCG; R, Tropic hormone (LH/hCG, FSH, ACTH) receptor.

cytosol [30-32]. The released cholesterol is either used directly for product formation (e.g., membrane biogenesis, steroid synthesis) or stored as cholesterol esters in the form of lipid droplets. The vesicles with empty receptors fuse with plasma membrane and deliver the LDL receptors to the cell surface for reuse. In addition to LDL, other plasma lipoproteins containing apoE (e.g., apoE-enriched rat or mouse high-density lipoprotein [HDL] are also processed via this endocytic pathway).

\section{Scavenger Receptor Class B, Type I (SR-BI)-mediated 'Selective' Uptake of the Cholesteryl Esters by Adrenal Gland and Ovary}

In contrast to humans, in the rodent adrenal and ovary, apoE-poor HDL-cholesterol is the preferential source of cholesterol utilized for steroidogenesis. The uptake of HDL cholesterol by steroidogenic cells, however, involves a unique pathway, termed 'selective' pathway in which cholesteryl esters (CEs) are selectively transferred to the cell interior without the parallel uptake and degradation of the HDL particle itself (Fig. 2) [33,34]. SR-BI, a multiligand cell surface receptor, binds HDL with high affinity and mediates selective cholesterol uptake [33,34]. The selectively delivered CEs are either hydrolyzed by the neutral cholesteryl ester hydrolase (CEH) and released as cholesterol used for steroiodogenesis, or stored in cellular lipid droplets $[33,35]$.

\section{Cholesterol Requirement of Testicular Leydig Cell}

The requirement for endogenously synthesized vs. plasma lipoprotein-derived cholesterol for testosterone synthesis in testicular Leydig cells also varies according to the species. For example, in the rodent (rat) Leydig cells, the cholesterol that is synthesized de novo within the cell is the most important source of testosterone synthesis [36-39], but in the human testis, both endogenously synthesized cholesterol as well as LDL-derived cholesterol contribute to testosterone production $[39,40]$. As noted above, all steroidogenic cells, however, contain the intracellular cholesterol pool in the form of cholesterol esters (lipid droplets) which are regarded as a short-term store of substrates that enables cells to respond rapidly to trophic hormone stimulation $[25,33,39]$.

\section{Hormonal Regulation of Steroidogenesis}

The type of a particular steroid hormone synthesized by a given steroidogenic cell type depends upon its sensitivity to a particular type of tropic hormone (Tables 2 and 3 ) and its genetically expressed complement of steroidogenic enzymes (Fig. 1). Thus, adrenocorticotropic hormone (ACTH) stimulates glucocorticoid (cortisol/corticosterone) in adrenocortical fasiculata-reticularis cells [41,42]; ACTH or angiotensin II increases mineralocorticoid, aldosterone synthesis in adrenal glomerulosa cells $[43,44]$; human chorionic gonadotropin 
Table 2. Major Steroid Synthesized by the Steroidogenic Cells of Adrenal, Ovary and Testis

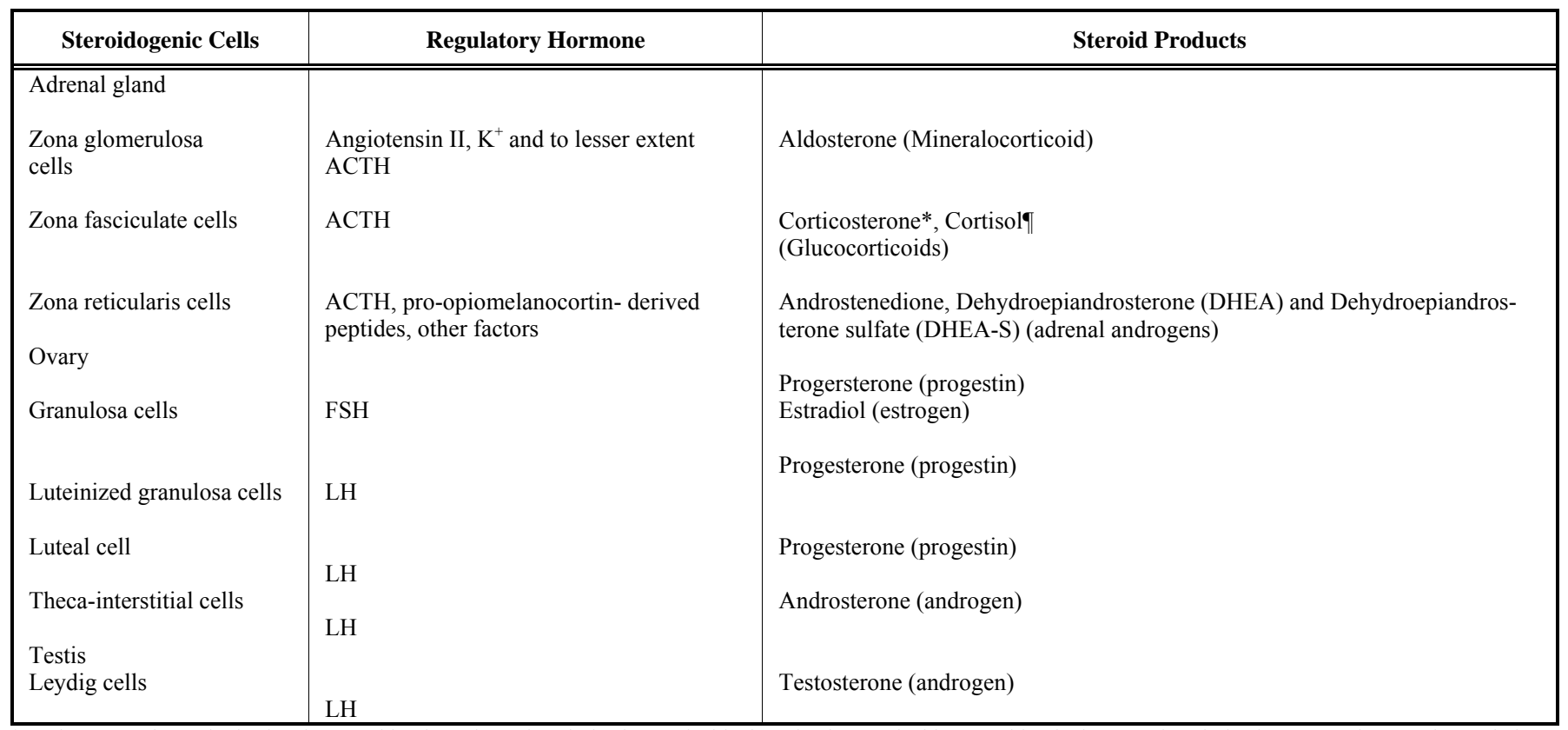

*Corticosterone is synthesized and secreted by the rodent adrenal gland. $\uparrow$ Cortisol is the sole glucocorticoid secreted by the human adrenal gland. ACTH, adrenocorticotropic hormone; LH, luteinizing hormone; FSH, follicle-stimulating hormone

Table 3. Major Enzymes Involved in the Biosynthesis of Adrenal and Gonadal Steroids

\begin{tabular}{|c|c|c|}
\hline Common Name & Old Designation & Current Designation \\
\hline Cholesterol-side chain cleavage enzyme; desmolase & $\mathrm{P} 450_{\mathrm{scc}}$ & CYP11A1 \\
\hline 3ß-Hydroxysteroid dehydrogenase & $3 \beta$-HSD & 3ß-HSD \\
\hline $17 \alpha$-Hydroxylase/17,20 lyase & $\mathrm{P} 450_{\mathrm{c} 17}$ & CYP17 \\
\hline 21-Hydroxylase & $\mathrm{P} 450_{\mathrm{C} 21}$ & CYP21A2 \\
\hline 11ß-Hydroxylase & $\mathrm{P} 450_{\mathrm{C} 11}$ & CYP11B1 \\
\hline Aldosterone synthase & $\mathrm{P} 450_{\mathrm{C} 11 \mathrm{AS}}$ & CYP11B2 \\
\hline
\end{tabular}

(hCG) or luteinizing hormone (LH) promotes progesterone synthesis in luteinized granulosa-luteal cells $[45,46]$; folliclestimulating hormone (FSH) stimulates progesterone and estrogen synthesis in granulosa cells $[47,48]$; and LH regulates androgen production both in theca-interstitial cells (androsterone) $[49,50]$ and testicular Leydig cells (testosterone) $[51,52]$.

The first reaction in the conversion of cholesterol substrate $\left(\mathrm{C}_{27}\right)$ to $\mathrm{C}_{21}$ (pregnenolone, progesterone, glucocorticoids and mineralocorticoids), $\mathrm{C}_{19}$ (androgens), and $\mathrm{C}_{18}$ (estrogens) steroids involves the cleavage of a 6-carbon unit from 27 carbon cholesterol to form the common steroid precursor, 21 carbon pregnenolone [2,3,6] (Fig. 1). This NADPH dependent reaction is catalyzed by the side-chain cleavage (SCC) cytochrome P450 (P450scc or CYP11A1) complex, which is comprised of a flavoprotein (NADH-adrenodoxin reductase), a $\mathrm{Fe}_{2}-\mathrm{S}_{2} *$ type iron-sulfur protein (adrenodoxin) and a hemoprotein CYP11A1 (P450scc) localized in the inner mitochondrial membranes of steroid producing cells $[2,3,6]$.

This initial reaction is the principal committed, regulated, and rate-limiting step in steroid biosynthesis. The rate limiting nature of this step is not determined by the activity of CYP11A1 (i.e., enzymatic conversion of cholesterol to pregnenolone), but rather delivery of cholesterol to the substrate site of CYP11A1 (translocation of cholesterol from outer to an inner mitochondrial [steroidogenic] pool readily accessible to CYP11A1) [53]. The tropic hormones, ACTH and gonadotropins (LH, FSH) acutely stimulate this process by facilitating the availability of cytosolic free cholesterol and its transport to and accumulation in the inner mitochondrial CYP11A1 sites. When steroidogenic cells are stimu- 
lated with tropic hormones in the presence of protein synthesis inhibitors such as cycloheximide, cholesterol accumulates in the outer mitochondrial membrane and is not transferred to the inner mitochondrial membrane [54-57]. Therefore, it has been proposed that a labile protein is required for cholesterol delivery to the inner mitochondrial membrane microdomains containing CYP11A1 [26,53,59].

The entire process of intracellular cholesterol transport to mitochondria can be broadly divided into two separate but equally important steps. In the first step, the tropic hormonemediated increased cAMP formation (second messenger) stimulates PKA [54,60], leading to phosphorylation (activation) of a cholesteryl esterase, which, in turn, hydrolyzes stored cholesteryl esters (in the form of lipid droplets) and generates increased concentrations of free cholesterol, the substrate for CYP11A1 [26,35]. Subsequently, the mobilized cholesterol is transported to the outer mitochondrial membrane. In addition, depending on cell type, the cAMP-PKA signaling cascade may also directly mobilize cholesterol from the plasma membrane or other cellular membranes to the outer mitochondrial membrane [27-29]. Because cholesterol is a hydrophobic molecule and diffuses poorly in an aqueous environment, a number of putative factors including cholesterol transport proteins such as sterol carrier protein $_{2}$ $\left(\mathrm{SCP}_{2}\right)$, steroidogenesis activator polypeptide (SAP), cytoskeleton components/structures, StarD proteins (see below) and changes in cellular architecture have been suggested to facilitate cholesterol transport to the outer mitochondrial membrane, however, their mechanisms of action have not been completely known [58].

The second critical step is the delivery of the cholesterol substrate to inner mitochondrial membrane sites of CYP11A1 [53,56,57]. As noted above, this step is considered rate-limiting because hydrophobic cholesterol cannot rapidly diffuse through the aqueous intermembrane space of the mitochondria to support acute steroid synthesis and requires the participation of a de novo synthesized labile protein [61-65]. The search for the putative regulatory protein identified several candidate proteins, namely SCP2, DBI, $\mathrm{SAP}$, peripheral benzodiazepine receptor (PBR), steroidogenesis inducing protein (SIP), and steroidogenic acute regulatory protein (StAR) [58].

Among them, the StAR protein possesses all the necessary characteristics of the acute regulator of steroid hormone biosynthesis in steroidogenic cells $[58,66]$, i.e., it is a synthesis specifically induced in the adrenal and gonads in response to tropic hormonal stimulation, is highly labile, and its expression is sensitive to the protein synthesis inhibitor, cycloheximide $[58,67]$. This candidate protein was initially described by Orme-Johnson and colleagues [64,65]. The discovery of mutations in the StAR gene in patients with lipid congenital adrenal hyperplasia was critical to the elucidation of the role of StAR protein in the acute steroidogenic response [68]. Lipoid congenital adrenal hyperplasia patients have markedly impaired gonadal and adrenal steroidogenesis [due to an inability to efficiently transport into the mitochondria] associated with a massive accumulation of cholesterol in lipid droplets] [68]. Deletion of the murine StAR gene by the homologous recombination yielded an identical phenotype of impaired steroidogenesis and lipid accumula- tion in the adrenal gland, and to a lesser degree in testicular Leydig cells and none in the ovary of StAR knockout mice [69]. StAR is synthesized as a short-lived cytoplasmic 37$\mathrm{kDa}$ protein with a mitochondrial leader peptide that is cleaved upon mitochondrial import to yield the long-lived intramitochondrial $30-\mathrm{kDa}$ form [58]. It is now wellestablished that StAR functions as a sterol transfer protein [70], binds cholesterol [71,72], mediates the acute steroidogenic response by moving cholesterol from the outer to the inner mitochondrial membrane [73], acts on the outer mitochondrial membrane [73-75], and requires the structural change previously described as a $\mathrm{pH}$-dependent molten globule [76]. StAR is also a prototype of a family of proteins that contain START (StAR-related lipid transfer) domains (StarD proteins) [77], of which StarD3/MLN64, StarD4, StarD5 and StarD6 exhibit steroidogenic potential [78,79].

Peripheral-type benzodiazepine receptor (PBR), recently renamed mitochondrial translocator (TSPO) has also been implicated in the transport of cholesterol across mitochondrial membranes in steroidogenic cells $[80,81]$. PBR is expressed ubiquitously on the OMM, but is most abundant in steroidogenic cells [80]. PBR ligands stimulate steroidogenesis and promote translocation of cholesterol from OMM to the IMM in testicular Leydig cells, ovarian granulose cells, and adrenocortical cells [81-85]. Targeted disruption of the PBR/TSPO gene in rat Leydig R2C cells (PBR-deficient cells) blocked the cholesterol import into the mitochondria and dramatically reduced steroid production, whereas reintroduction of PBR/TSPO in this cell line restored steroidogenesis [86,87]. Likewise, mutation of a single amino acid residue in the "cholesterol recognition amino acid consensus" domain in the carboxyl-terminal region disrupts cholesterol binding and transfer to IMM [76,87]. PBR/TSPO is a component of the multimeric $140-200-\mathrm{kDa}$ complex located on the OMM especially at the OMM-IMM contact sites. The complex consists of $18-\mathrm{kDa}$ PBR or TSPO itself (and its polymorphic forms), the $34 \mathrm{kDa}$ voltage-dependent anion channel (VDAC), the $30-\mathrm{kDa}$ adenine nucleotide translocator (ANC), a 10-kDa protein (pk 10), PBR-associated protein 1 (PRAX-1), and the PBR and protein kinase A (PKA) regulatory subunit RI $\alpha$-associated protein (PAP7) [88].

Multiple lines of evidence now indicate that PBR and StAR are likely to work in concert in mediating the movement of cholesterol from OMM to IMM. Although a physical interaction between StAR and PBR/TSPO has not been established, FRET measurements indicated that StAR/StarD1 and PBR/TSPO come within the $100 \mathrm{~A}^{\circ}$ of each other [89]. Moreover, Hauet et al [87] reported that isolated mitochondria from mouse Leydig MA-10 cells that express the Tom20/StAR fusion construct produce steroids at a maximal level, but if the cells are treated with PBRantisense oligonucleotides, their ability to synthesize the steroid is lost; on the contrary, re-introduction of recombinant PBR into the mitochondria in vitro rescued the steroidogenesis [87,90]. Liu et al., [91] provided evidence that hormonal stimulation of a Leydig cell line leads to formation

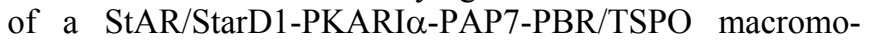
lecular signaling complex on the outer mitochondrial membrane that mediates the effect of hormones on mitochondrial cholesterol transport and steroidogenesis. Recently, evidence is presented to suggest that StAR interacts with VDAC1, and 
with phosphate carrier protein $(\mathrm{PCP})$ on the $\mathrm{OMM}$ to initiate the action of StAR [92]. These studies further point to a functional cooperation between the PBR/TSPO and StAR/StarD1 proteins and possibly participation of many other proteins as well $[76,88,90,93,94]$.

\section{Steroidogenic Steps and Enzymes Involved in Biosynthe- sis of Steroids in a Tissue-specific Manner}

Following cholesterol transport to mitochondria, it is cleaved by the cytochrome P-450 side-chain cleavage ((P450scc; CYP11A1), adrenodoxin, and flavoprotein system to generate pregnenolone $[2,3,6]$. Pregnenolone is then shuttled from the mitochondria to the smooth endoplasmic reticulum where it is converted to progesterone by $3 \beta-$

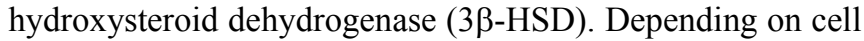
type, the pregnenolone and progesterone are further metabolized to sex steroids or corticosteroids (Fig. 1). In testicular Leydig cells, the synthesis of testosterone can occur through two biosynthetic pathways: the $\Delta^{-5}$ pathway and $\Delta^{-4}$ pathway. In man the major pathway of biosynthesis is via $\Delta^{-5}$ pathway including pregnenolone, 17-hydroxypregnenolone, and androstenediol. In other species, testosterone biosynthesis proceeds via the $\Delta^{-4}$ pathway including progesterone, 17hydroxyprogesterone, and androstenedione.

The principal steroid-producing cells of the ovary, namely the granulosa, theca and corpus luteum cells, possess the complete enzymatic complement required for steroid hormone formation. The main pathway of steroid hormone synthesis in the human corpus luteum is the $\Delta^{-4}$ pathway which involves the conversion of pregnenolone to progesterone. In the human ovarian follicle, the $\Delta^{-5}$ pathway is the preferred pathway for the formation of androgens and estrogens, because theca cells of the human ovary metabolize 17hydroxypregnenolone more efficiently than 17-hydroxyprogesterone. However, the predominant steroid differs among each of these cell types so that the corpus luteum primarily forms progesterone and 17-hydroxy progesterone in response to $\mathrm{LH}$, the theca and stromal cells secrete androgen, and the granulosa cells secrete estrogen predominantly. LH regulates the first step in steroid hormone biosynthesis by controlling the conversion of cholesterol to pregnenolone and its subsequent metabolism to androgens in theca cells, whereas FSH (possibly plus LH) controls conversion of androgens to estrogens in granulose cells.

In zona fasiculata cells of the adrenal cortex, progesterone is hydroxylated to $17 \alpha$-hydroxyprogesterone by CYP17 which is subsequently metabolized to 11-deoxycortisol (or deoxycorticosterone by CYP21A2. The final step in cortisol biosynthesis takes place in the mitochondria and involves the conversion of 11-deoxycortisol to cortisol by the enzyme CYP11B1. The C17,20 lypase activity associated with CYP17 of zona fasciculate and zona reticularis cells catalyzes the production of androgens, dehydroepiandrosterone (DHEA) and androstenedione. In the zona glomerulosa cells, progesterone is 21-hydroxylated by the enzyme CYP21A2 to yield 11-deoxycorticosterone. The next two steps in aldosterone biosynthesis are catalyzed by aldosterone synthase (CYP11B2) which converts 11-deoxycorticosterone to corticosterone and subsequently to aldosterone $[2,3,6]$.

\section{AGING AND TESTOSTERONE SECRETION}

\section{Humans}

It is well-recognized as men age, plasma testosterone concentrations decline gradually after age 40 , albeit with considerable variability between individuals $(\sim 0.4$ to $2.6 \%$ per year) $[95,96]$. As early as $50-60$ years ago it was realized that aging is accompanied by significant reduction in testosterone levels [97,98]. Although some follow-up studies failed to detect age-related decline in plasma testosterone levels in older men [99-104], subsequent population-based cross-sectional and longitudinal studies have confirmed progressive loss of testosterone with aging in healthy men [96,105-122]. Mirroring this decline in plasma testosterone concentration is an age associated increase in sex-hormonebinding globulin (SHBG) level [117], a major plasma carrier of testosterone, resulting in even more dramatic decreases in unbound free testosterone [110,123-125], and weakly bound bioavailable testosterone [126,127]. [In healthy male adults, circulating testosterone exists in three forms: testosterone strongly bound to SHBG, testosterone weakly bound to albumin and free testosterone]. Approximately $80 \%$ of the plasma testosterone is bound to SHBG and is not bioavailable. The remaining $20 \%$ is biologically active and consists of both weakly albumin-bound and free testosterone. According to one study, the Longitudinal Massachusetts Male Aging Study, total plasma testosterone decreases at a rate of $1.6 \%$ per year, while bioavailable testosterone decreases at a rate of $2-3 \%$ per year [117]. In contrast, levels of SBG increase $1.2 \%$ per year. The overall impact of these changes is not only a significant decrease in all three subfractions of testosterone, but also a significant shift toward functionally inactive bound testosterone as compared to bioavailable free testosterone.

Decreased testosterone availability in aging has been associated with parallel age-related decline in bone density, muscle mass, muscle strength, physical function, and sexual function [96,120-122,124,128]. Epidemiological studies have also correlated hypoandrogenemia with impaired quality of life, frailty, depressive mood and subtle impairments in cognitive function $[122,124,125,128]$. More recently, lowcirculating testosterone has been linked to age-related metabolic abnormalities including body-wide reductions in rates of protein synthesis, abdominal obesity, diabetes, prediabetic states (insulin resistance, impaired glucose tolerance and metabolic syndrome), dyslipidiemia (alterations in LDL and HDL and plasma triglycerides) and increased risk of cardiovascular disease $[125,129]$. Although the precise causes have not been clarified, lower testosterone levels in the elderly male population is likely to result from defects in the hypothalamus, pituitary gland and/or testis [96,120,130-132]. The age-related decreases in testosterone secretion have been related to structure and function of Leydig cells. Several potential mechanisms for the loss of Leydig cell function has been proposed including: a) a reduction in Leydig cell number; b) a normal number of cells, each having defects in one or more enzymatic steps involving testosterone biosynthesis; c) a normal number of cells with reduced responsiveness to trophic hormone (luteinizing hormone or LH); and d) Leydig cell degeneration and dissolution [130,133]. 
There have been many reports linking age-related alteration in testosterone levels with the number and morphology of human Leydig cells. Sarjent and McDonald were the first to report significant reduction in Leydig cell number in autopsy samples of men with an age greater than 20 years [134]. Decreased Leydig cell numbers have also been reported by Tillenger [135], Frick [136], Harbitz [137] and Kaler and Neaves [138]. In contrast to these findings, Sniffen, [139], as well as Sokal [140] observed no loss of Leydig cells with age, while Kothari and Gupta [141] reported total Leydig cell mass to be increased in testes from their older men. Besides, a number of studies have also shown impaired testicular responsiveness to hCG stimulation [103,104,133,143-146] or to recombinant human LH $[147,148]$ stimulation in aging men. Harman and Tsitouras [103], Nieschlag et al., [104], Rubens et al., [144], Nieschlag et al., [142], and Nankin et al., [146] all noted decreases in both the absolute and relative (i.e., ratio of stimulated to basal) testosterone responsiveness in elderly as compared to young men.

Relatively less information is available about the potential causes of the reduction in Leydig cell number and their responsiveness to $\mathrm{LH} / \mathrm{hCG}$ stimulation during aging. The work of Sasano and Sadatoshi [149] and Takizawa and Hatakeyama [150] has demonstrated that changes in the microvasculature of the testis may be indirectly responsible for degenerative changes seen in the Leydig cells of older individuals. Several studies have provided evidence that loss of Leydig cell population in the adult human testis as a function of increasing age is caused by Leydig cell hyperplasia, dedifferentiation, degeneration and dissolution [151-153]. In addition, there is evidence for an impaired hypothalamic GnRH outflow and decreased pulse generation of GnRH, with pulses being generated more irregularly, normal or enhanced LH secretion when stimulated by exogenous GnRH pulses, reduced pulsatile LH-stimulated testosterone synthesis, and decreased negative feedback in older men [131,132,154156]. From the above discussion, it is quite apparent that multiple alterations in hypothalamic-pituitary-testicular axis lead to the age-related decline in testosterone synthesis and secretion. In addition, with aging, the normal circadian rhythm of testosterone secretion is lost $[132,133]$.

\section{Experimental Animals}

Use of experimental animals to study the effects of aging on Leydig cell steroidogenesis is advantageous in terms of the flexibility with which experiments can be designed and the availability of tissues and cells for more mechanistic studies. However, it should be pointed out that experimental findings derived from laboratory animals may not be entirely applicable to the human situation, since it appears that the patterns of hormone changes vary considerably from species to species and even from strain to strain. The rat is the most popular laboratory animal to examine the effects of aging on testicular androgen synthesis and secretion. A number of studies carried out during the past few decades have led to a clear demonstration that aging leads to significant reduction in blood testosterone levels in several rat strains [157-169].

One study reported both a reduction in circulating testosterone levels and loss of diurnal rhythm for testosterone in the older rats [170]. Similar to the age-related loss of basal blood testosterone concentrations, the acute response $(<1-4 \mathrm{~h})$ of the rat testis to gonadotropin (hCG) stimulation in vivo is also impaired in older rats [171-173]. Moreover, chronic hCG treatment (3-7 days) was shown to restore plasma testosterone levels of older rats to levels comparable to those of similarly stimulated young mature Wistar [173] or LongEvans [174] rats. In contrast, treating rats for up to three weeks with hCG, Lin et al., [175] were unable to restore testosterone levels in 24-month old Sprague-Dawley rats to values seen in identically treated young mature rats.

There is no consensus whether or not aging also affects the quantity, structure or the organelle content of testicular Leydig cells. A number of studies indicate that the number of Leydig cells per testis is either unchanged or increased [162,176-178]. In contrast, occurrence of Leydig cell hyperplasia as a consequence of aging has also been reported in stallions [179] and humans [141]. Other studies suggest that Leydig cells undergo atrophic changes in size $[168,169,176,180]$ and organelle content [178] with aging. Bethea and Walker [181] provided evidence showing that aging leads to decreased Leydig cell mass, at least in testis of Fischer rats.

When specifically challenged in vitro, isolated Leydig cells of older rats of several different strains show significantly less steroidogenic response to tropic hormone stimulation than do cells from young animals $[162,175,178,181$ 183]. Only studies conducted by Kaler and Neaves [177] reported no significant differences in testosterone production by isolated Leydig cells from old rats as compared to similarly isolated cells from young controls [177]. Tsitouras et al., [184] reported that in vivo pretreatment with, but not in vitro exposure to, hCG reverses the testosterone secretory defect of Leydig cells from old rats. Overall, these changes appear not to be a function of gonadotropin receptor activity, or cAMP formation $[162,177,182,183,185,186]$ or a defect in the steroid hormone synthesizing enzymes $[176,186]$ although there are some exceptions to this. For example, Pirke et al., [162] reported significant loss of hCG binding to whole testicular membranes of old rats, while Tsitouras et al., [182] observed only a modest decrease in hCG binding to membrane preparations from the purified Leydig cells. Likewise, aged Leydig cells from Brown Norway rats also exhibited a significant reduction in gonadotropin (LH) receptor content [187]. Contrary to these findings, other investigators failed to observe any reduction in gonadotropin binding either in vivo [162] or in vitro [177,185,188]. In addition, gonadotropin stimulation of cAMP production and PKA activity in Leydig cells was unaffected by the aging process $[182,183,186]$. Two reports, however, have provided evidence suggesting that aging negatively impacts on cAMP production and cAMP-stimulated PKA activity in Leydig cells and that such reduction in the cAMP signaling cascade may be functionally linked to decreased testosterone synthesis and secretion seen with advancing age $[189,190]$. On the other hand, studies from our laboratory indicate that testosterone secretory response to LH (endogenous gonadotropin), cholera toxin (a nonspecific stimulator of adenylate cyclase), forskolin (stimulator of adenylate cyclase) and cAMP agonists (e.g., $\mathrm{Bt}_{2} \mathrm{cAMP}, 8 \mathrm{Br}$-cAMP, 8CPT-cAMP), like hCG, is reduced by $60-70 \%$ in purified Leydig cells from older 
animals [183]. These latter studies and others [184,186] strongly support the possibility that the 'aging' defect in the Leydig cells occurs beyond the hormone receptor binding and hormone-stimulated cAMP signaling cascade.

There is some evidence that aging affects the functional expression of certain steroidogenic enzymes involved in the conversion of cholesterol to testosterone in Leydig cells. Total testicular $\Delta^{5}-3 \beta$-hydroxysteroid dehydrogenase $/ \Delta^{5}-\Delta^{4}$ isomerase (3 $\beta$-HSD) activity, which converts pregnenolone $\rightarrow$ progesterone, 17 $\alpha$-hydroxypregnenolone $\rightarrow 17 \alpha-$ hydroxyprogesterone and dehydroepiandrosterone $\rightarrow$ androstenedione (Fig. 2), has been reported to be decreased in old Long Evans rats, and this reduced activity was fully restored following hCG treatment of old animals in vivo [191]. Extensive studies carried out by Zirkin and colleagues $[188,191,192]$ further demonstrated that the activity of CYP11A1 (P450scc), which catalyzes the conversion of cholesterol to pregnenolone, as well as $3 \beta-\mathrm{HSD}, 17-\mathrm{KSR}$ and individual activities of CYP17 (P450 17 ), namely $17 \alpha-$ hydroxylase and C17-20 lypase activities, which mainly convert progesterone to $17 \alpha$-hydroxyprogesterone and androstenedione, respectively, decrease with aging. Western blot analyses revealed age-related changes in CYP11A1, $3 \beta-$ HSD and CYP17 that were consistent with enzymatic activity analyses $[188,190,192]$. In contrast, no changes in testicular 33-HSD were noted by Lehmann et al [176].

Chan et al., [193] made an interesting observation that when dissected testes of old Long-Evans rats were incubated with $\left[{ }^{3} \mathrm{H}\right]$ progesterone, they generated less testosterone and $5 \alpha$-androstene- $3 \alpha, 17 \beta$-diol but produced similar amounts of $17 \alpha$-hydroxyprogesterone, androstenedione, and $5 \alpha-$ dihdrotestosterone (DHT) and large amounts of an inactive metabolite of testosterone, $7 \alpha$-hydroxyprogesterone, as compared to young rat testis. From these observations, the authors concluded that a shift towards increased formation of $7 \alpha$-hydroxyprogesterone is responsible for lower testosterone production in old rats. Liao et al., [183] reported that the in vitro defect of testosterone production in old Leydig cells is not observed when an incubation medium is supplemented with freely-diffusible steroid precursors, 25-hydroxycholesterol, 20 $\alpha$-hydroxycholesterol or 22(R) hydroxycholesterol, i.e., aging showed no inhibitory effect on hydroxycholesterol-supported steroidogenesis. These results were interpreted to suggest that aging interferes with the events connected with the intracellular cholesterol mobilization and its transport to mitochondria [183]. Indeed, it has been shown by the same authors that aging directly affects LH-mediated cholesterol transfer into and within the mitochondria [183]. This conclusion is further supported by the observation that significant decreases occur in the expression of StAR/StarD1 $[194,195]$ and PBR/TSPO [196,197] proteins, which are now recognized as crucial players in facilitating cholesterol transport to mitochondria for steroidogenesis.

The impact of aging on testicular steroidogenesis has also been studied in mice, but not as extensively as in rats. Eleftheriou and Lucas [198] and Nelson et al., [199] reported that plasma testosterone levels were similar in both young and old mice. In contrast, Bronson and Desjardins [200] and Coquelin and Desjardins [201] all observed lower levels of plasma testosterone, $\mathrm{LH}$, but not FSH in mice of $18-30$ months of age. Likewise, a recent study reported that the plasma testosterone and androstenedione levels in old mice (18-19 months of age) on a heterogeneous genetic background derived from the Ola-BALB/cJ, C57BL/6J, and $\mathrm{C} 3 \mathrm{H} / \mathrm{J}$ strains, were lower as compared to young mice (3-4 months of age) of a similar genetic background [202]. In addition, plasma testosterone responses to LH stimulation were attenuated in old mice, whereas plasma androstenedione responses were insensitive to aging [202]. Given these conflicting reports, obviously more studies are needed to firmly establish the effects of aging on testosterone production in mice.

\section{AGING AND SECRETION OF FEMALE SEX- STEROIDS}

Substantial and important age-related changes also occur in the ovary leading to a gradual decline in the reproductive potential of women with advancing age. Undoubtedly, the most widely recognized aging effect on the reproductive system in women is the age-associated transition from the normal cycling ovary to perimenopause to the menopause state. By the mid-sixth decade of life, all women undergo menopause, which is characterized by the permanent cessation of menstruation resulting from exhaustion of the ovarian follicular reserve as well as loss of their activity. Ovarian follicles are the source of fertilizable ova for reproduction, and are also responsible for biosynthesis of sex steroids, progestin, androgens and estrogens, all of which are essential for normal reproductive function and maintenance of fertility. Although age-associated depletion of ovarian follicles is the ultimate cause of menopause and end of reproductive function in females, concomitant hormone changes including sex steroids also contribute significantly to ovarian aging.

The purpose of this section is to summarize our current knowledge about the age-related alterations in human ovarian steroid hormone synthesis and their relevance to menopause. Although significant information is also currently available about the impact of aging on ovarian steroidogenesis using experimental animal models [203-211], to conserve space and given the fact that physiological events connected with the reproductive cyclicity and ovarian sex steroid synthesis in animals, particularly rodents, are significantly different from that of humans, we will restrict our discussion to the aging human ovary only. Also, although aging is known to indirectly influence the ovarian steroid hormone production through modulation of the hypothalamic-pituitaryovarian axis, again, due to space constraints, this aspect of ovarian regulation will not be discussed here, but interested readers may wish to consult several recent excellent reviews that specifically cover this topic [212-216]. Likewise, there are excellent reviews covering the entire spectrum of the pathophysiology of early and late menopause [217-221].

As noted before, the ovarian sex steroids, estrogens, androgens and progestin are primarily synthesized in the ovarian follicles. The follicle possesses two distinct steroidogenic cell types, which are highly compartmentalized but cooperate functionally to biosynthesize from cholesterol, progestin, androgens and estrogens in a sequential manner, with each serving substrate for the subsequent steroid production in the pathway $[222,223]$. The LH responsive theca cells are re- 
sponsible for the production of androgens mainly androstenedione, which serves as a precursor for estrogen production in follicular granulosa cells by a process commonly referred to as aromatization [224]. These cells express relatively high-levels of three enzymes, cholesterol side-chain cleavage (P450scc, CYP11A), 3 $\beta$-hydroxysteroid dehydrogenase (3ßHSD) and 17 $\alpha$-hydroxylase/17,20 lypase (P450c17, CYP17) which sequentially catalyze the conversion of cholesterol to pregneolone to androstenedione [225]. The theca-derived androgens are transported to the adjacent granulosa cells for their conversion to estrogens.

The granulosa cell steroidogenesis and aromatization of androgens (androstenedione and testosterone) to estrogens is regulated by FSH during the follicular phase and LH during the luteal phase of the cycle. The granulosa cells) are also responsible for progesterone synthesis. These cells undergo hormone-mediated differentiation in the luteal phase of the menstrual cycle, transforming them from the primarily estrogen producing cells to mostly progesterone secreting cells. Likewise, granulosa cells exhibit high expression of aromatase activity during the follicular phase and high $3 \beta \mathrm{HSD}$ during the luteal phase. The granulosa cells do not express $17 \alpha$-hydroxylase/17,20 lypase activity, thus necessitating the need for the development of an integrated process involving two cells (theca and granulosa cells) and two gonadotropins (LH and FSH) to facilitate estrogen production.

Changes in the circulating levels of ovarian steroids, estradiol and progesterone together with those in the levels of circulating of gonadotropins, LH and FSH during the normal menstrual cycle have been well documented [226]. In brief, plasma levels of estradiol begin to rise around the mid-point of the follicular or proliferative phase, increasing almost linearly for the last few days, and reach a maximum level 1 day before ovulation (i.e., LH and FSH peaks) [226,227]. Thereafter, estradiol levels decline rapidly, rise slightly during the middle of the luteal or secretory phase and, subsequently, decline rapidly reaching a basal level shortly before the initiation of menstruation and the next cycle [226,211]. The plasma levels of progesterone remain low in menstrual phase and follicular phase, but rise steadily following ovulation reaching maximum levels around the middle of the luteal phase and decline rapidly afterwards reaching a baseline shortly before the onset of the menses [226,227]. In contrast to these fairly predictable changes in estradiol, progesterone and gonadotropin levels throughout the menstrual cycle during the fertility period, such changes become highly erratic with variable relationships between sex steroids, LH and FSH, the occurrence of ovulation, and initiation of menstruation in response to the aging-induced menopausal transition (MT) and postmenopausal period [228-231].

The earliest evidence about the alterations in hormone levels occurring with advancing reproductive age was provided by Sherman and Korenman [232]. They reported that older women (46-51 years) undergoing MT (less functional ovarian follicles) had elevated levels of serum FSH along with decreased concentrations of estradiol, as compared to young women of 18-30 years of age [232,233]. LH and progesterone were comparable between the two groups $[232,233]$. Another study conducted by MacNaughton et al [234] reported that average FSH levels were two times higher in normal cycling women of 45-49 years of age as compared to three younger age groups. Serum estradiol levels were also lower in the same age group, but LH levels did not vary significantly in any of the age groups. Recent largescale cohort studies conducted in Australia [235-238], Norway [239], and United States [240] have provided further important insights into the overall pattern of ovarian sex steroids and gonadotropins that occur during the MT. It is reported that circulating FSH levels rise progressively during the MT and that in perimenopausal women estradiol production fluctuates with FSH and often reaches higher concentrations than those in young normal cycling women below the age of 35. On the other hand, estradiol levels do not decrease appreciably until late in the MT. Despite the continuing regular cyclic menstruation, progesterone levels during the early MT are lower than in women of mid-reproductive age. Testosterone levels do not vary significantly during the MT.

By the time the postmenopausal period sets in, estrogen and progesterone decrease dramatically but testosterone levels decrease to a lesser extent $[241,242]$. The postmenopausal ovary still contributes approximately about $40-50 \%$ of all of the circulating testosterone [241-243]. Rannevik et al [244] carried out a longitudinal study in which 160 healthy 48-year-old enrolled women were followed for 12 years throughout the menopausal transition. They reported that both estradiol and estrone levels decreased significantly right at the onset of menopause. Following menopause, estradiol continued to show moderate but linear decline [242]. On the other hand, estrone levels did not change appreciably in response to menopause presumably due to increased peripheral aromatization of adrenal androstenedione, and which eventually became the primary source of estrogen during the postmenopausal years $[242,244]$. Significant decreases in the circulating levels of other sex steroids such as DHT, androstenedione and DHEA have also been reported in postmenopausal women as compared to women of reproductive age [243]. During the postmenopausal period, both LH and FSH concentrations remain highly elevated partially due to a decrease in negative feedback from ovarian steroids [228,229,245-247]. Elevated circulating levels of LH may also be responsible for enhanced androgen production by the theca cells as well as follicular atresia.

\section{AGING AND GLUCOCORTICOID AND MINER- ALOCORTICOID SECRETION}

\section{Humans}

Studies aimed at determining the impact of aging on basal, nonstimulated HPA function have produced mixed results. A majority of studies have shown that basal circulating levels of cortisol [248-266 and references therein] do not vary significantly with aging in humans. These analyses included the varying gender population as well as the health status of subjects with some using samples from males only [248,249,256,260-262], others employing both men and women [252-255,257,259,262,265], some from subjects classified as 'normal healthy' [248,249,256,260-262], and others from hospitalized patients $[251,252,257,262]$. Few studies have reported decreased [267,268], or increased [269-273] cortisol levels. Interestingly one report comparing the age-related changes in cortisol in men and women sug- 
gests that women exhibit much greater age-related increases in cortisol secretion, with postmenopausal women showing the highest increases [269].

Numerous studies have reported that diurnal rhythmicity of cortisol [254,257,269-280] and ACTH [238,263] is also unaffected by aging in both sexes, but there are some exceptions. For example, some studies reported higher evening [251,281] and morning [278] cortisol levels at older ages; higher $24 \mathrm{~h}$ mean cortisol concentrations at older ages have also been reported in both men and women [269,270,272, $281,282]$. Other studies have reported no such age effect [280,283]. Interestingly, a recent study reported that 24-h cortisol levels were lower in men and higher in women with age [284]. This was attributed to decreased ACTH efficacy with age in men and increased ACTH efficacy with age in women [284]. Shifts in the timing of circadian peaks at older ages with later [285] or earlier morning peaks have also been reported [282,283]. Many follow-up studies particularly by Van Caulter et al., [269], Dueschle et al., [270], Yen and Laughlin [272], Kern et al., [286], and Magri et al., [287] further confirmed that circadian rhythms remain generally unchanged with age for ACTH and cortisol, but significant alterations do occur. The level of the nocturnal nadir cortisol progressively increases with aging [253,254,269,270], leading to a decline of the diurnal amplitude [269,270]. Moreover, the timing of the nocturnal nadir phase is advanced with aging [269,270,286,287], and the evening quiescent period shortened [269,270]. While the diurnal amplitude of ACTH also declines with age [270], ACTH levels were found to be either unchanged [287] or only moderately elevated [270].

Other studies suggest that aging augments ACTH and cortisol release in both sexes after selected stressors [288292]. Raskind et al., [293] compared serum cortisol levels in young and elderly individuals in response to an infusion of hypertonic saline. The older group had a higher cortisol level after the infusion leading to the conclusion that aging is associated with an increased cortisol release to stimulatory events. Gotthard et al., [290] reported that cognitive challenges caused a greater rise in cortisol in the elderly than in the young. Consistent with this, Born et al., [289] reported that basal levels of ACTH were lower in the younger subjects compared to older male and female subjects and that older subjects of both sexes had much greater response to the CRF (corticotrophin releasing factor) stimulation. Furthermore, Peskind et al., [294] found that the administration of the pharmacological doses of physostigmine leads to more robust increases in ACTH and cortisol in the older subjects than in the young raising the possibility that the elderly have a more responsive HPA (hypothalamic-pituitary-adrenal) axis. In addition, there are a large number of other studies describing the age-related alterations in human HPA response to ACTH or DEX challenge. These studies are nicely summarized in a review article by Seeman and Robbins [262] and will not be discussed here.

\section{Experimental Animals}

Extensive literature exists about the influence of aging on plasma glucocorticoid and mineralocorticoid levels, particularly rodent plasma corticosterone levels under basal condi- tions and in response to treatment with various stressors or ACTH. Table 4 summarizes findings of some of these reports. It is apparent that both basal and stress-induced corticosterone levels differ markedly among various strains of rats and mice and also among the same strain when examined by different laboratories. Some of these variations may be due to various compensatory mechanisms operating in rodent models, increased or decreased disposal rates of the corticosterone or changes in binding proteins. But, when specifically challenged in vitro, isolated adrenocortical cells [295-302] of older male rats of several different strains show significantly less hormone response to maximal ACTH or cAMP stimulation than do cells from young or adult animals. Further studies from our own laboratory have shown that these changes in steroid hormone production and secretion are not a function of reduced ACTH receptors, cAMP production, cAMP phosphodiesterase, steroidogenic enzymes or lipoprotein-mediated cholesterol delivery and the major alteration in the respective cell types occurs distal to cAMP generation [297,298,303-305]. In contrast, several reports from one laboratory, however, suggests that the adrenocortical cells isolated from aged female rats in fact possess an enhanced capacity to secrete corticosterone in response to ACTH stimulation than cells from young or adult animals [306-310]. Finally, there is also evidence for age-related impaired aldosterone secretion by the isolated rat adrenal capsules and glomerulosa cells [311,312].

\section{AGING AND ADRENAL ANDROGEN SECRETIONS}

\section{Humans}

Dehydroepiandrosterone (DHEA) and its sulfated form, dehydroepiandrosterone-sulfate (DHEAS) represent the major androgens secreted by the human adrenal gland [313315]. They are commonly referred to as the adrenal androgens. Although a small fraction of the circulating pool of DHEA is derived from gonads, the adrenal produces the bulk of circulating DHEA (S) [313-315]. It has been reported that plasma DHEAS levels in adult men and women are 100-500 times higher than those of testosterone and are 1000 to 10,000 times higher than those of estradiol [3,4], thus, providing a large reservoir for conversion into androgens and/or estrogens in peripheral intraendocrine tissues. Indeed, it is estimated that $30-50 \%$ of total androgen in men is synthesized in peripheral tissue, whereas in women, peripheral estrogen formation may be even greater [317]. Both DHA and DHEAS, however, are relatively less biologically active than other androgens.

The DHEA(S) shows a most striking age-related synthesis and secretion pattern that are unique to humans and nonhuman primates [313-322]. In humans, it occurs at three life stages as classified by Conley et al [319]: a) in utero from the fetal zone (FZ) cells of the developing adrenal cortex; b) during adolescence with the onset of adrenarche and the development of the zona reticularis (ZR); and c) in ever decreasing amounts from the ZR with advancing age. Before birth, DHEA(S) are produced in the fetal zone of the adrenal cortex early in gestation and production therein increases progressively through the second and third trimesters $[3,6,9,11-13]$. Immediately after birth, circulating DHEA(S) 


\section{Table 4. Effect of Age on Plasma Corticosterone Levels in Rodents}

\section{Brown Norway (BN) Rats}

- van Eekelen et al., [430] reported that total plasma cholesterol measured in blood samples collected between 0700-0900 did not differ between young (36-mo) and old (30-33-mo) rats. Likewise, corticosterone responses to novelty stress over a 4-hour period were comparable between young and old rats.

- In a follow-up work, van Eekelen et al., [431] demonstrated that stress-induced peak circulating corticosterone levels were not different between two age groups, but in vivo sensitivity of adrenal glands to in vivo $\mathrm{ACTH}_{1-24}$ challenge was reduced in aged (29-30-mo) compared to young (6-mo) adrenal glands. However, neither the magnitude of response to $\mathrm{ACTH}_{1-24}$ nor total capacity of the adrenal cortex to synthesize and secrete corticosterone in response to $\mathrm{ACTH}_{1-24}$ stimulation was impacted by aging.

- Gruenewald et al., [432] using young (3-mo), middle-aged (13-mo) and aged (23-24-mo) male Brown Norway rats showed that corticosterone levels over a 24-hour period significantly and progressively declined with advancing age.

\section{Fisher 344 (F344) Rats}

- Sencar-Cupović and Milković [433] observed no changes in plasma corticosterone levels in response to advancing age.

- Landfield et al., [434] observed significant increases in aldosterone and corticosterone levels in the mid-aged (13 mo) as compared to the young (4 mo) Fisher 344 rats. In the aged $(25 \mathrm{mo})$ animals, the circulating levels of these corticosteroids were reduced to levels similar to those seen in young animals. However, the mean plasma concentration of corticosterone was elevated in aged rats.

- Brett et al., [435] found no change with age (young 3- to 6-mo vs old 24- to 27-mo) in either sex in basal corticosterone levels, no change with age in males in stress-induced increments in corticosterone, and no change with age in males in stress-induced elevations in corticosterone, but a reduction in elevations induced by more potent stressors.

- Sapolsky et al., [436] reported elevation of basal corticosterone levels with advancing age (ranging from 3- to 27 months of age). Older animals showed no impairment in their capacity to respond to stressors such as cage transfer, cold exposure, or immobilization stress. More importantly, the authors demonstrated that older animals recover from and adapt to stress in a delayed and incomplete manner.

- Sapolsky et al., [437] noted comparable corticosterone levels in aged (24-26 mo) and young (3-5 mo) control rats under both basal and stressed conditions. In addition, it was reported that at the cessation of stress, corticosterone levels in young animals declined to basal levels within 90 min, whereas old animals still displayed high corticosterone levels even after $3 \mathrm{~h}$.

- Sapolsky et al., [438] reported that aged rats $(24-28 \mathrm{mo})$ secreted excessive amounts of the corticosterone under basal conditions as compared to young mature (3-5 mo), following the end of stress and during habituation to mild stressors. The old rats also showed resistance to inhibitory effects of the synthetic glucocorticoid dexamethasone upon subsequent corticosterone secretion.

- Sonntag et al., [439] found no age-related changes in the diurnal rhythm or concentrations of plasma corticosterone, when plasma samples were analyzed from young (3-4 mo), middle-aged (10-12 mo) and old (22-24 mo) male rats.

- As reported by Lorens et al., [440], the basal plasma corticosterone levels in the young (7 mo) and aged (22 mo) rats did not differ significantly when measured between 09:00-13:30. In contrast, the stress-induced increase in corticosterone levels were of greater magnitude in aged rats (155\% compared to their age-matched control) as compared to young rats (88\% higher compared to young control group), suggesting that stress leads to an exaggerated corticosterone in the aged rats.

- Irwin et al., [441] reported that basal concentrations of plasma corticosterone and stress responses were similar in aged (24-mo) and young (4-mo) old F344 rats.

- Cizza et al., [442] showed that basal corticosterone levels were lower in aged (24-mo) old rats as compared to young mature (8-mo) old rats. It was further shown that ACTH-induced corticosterone response was significantly lower in the middle-aged (18-mo) and aged (24-mo) rats when compared against young (2-mo) or young mature (8-mo) old rats.

- Hauger et al., [443] reported that elevated diurnal trough levels of corticosterone in aged rats (24 mo) compared to young rats (4 mo). During the circadian peak in the evening, aged rats exhibited a small but significant reduction in circadian peak corticosterone compared to the young rats.

- Morano et al., [444] provided evidence that young (5-6 months) and old (26-27 months) exhibited similar circadian rhythm of plasma corticosterone. Furthermore, they demonstrated that aged rats exhibit an aberrant stress response during both the light phase and the onset of the dark period of the cycle.

- Cizza et al., [445] reported a significant decline in plasma levels of corticosterone in response to advancing age. Treatment (iv) with two doses of CRF (2 and $20 \mu \mathrm{g} / \mathrm{kg} \mathrm{BW}$ ) resulted in significantly greater corticosterone responses in older rats (18-mo and 24-mo). Treatment with $\mathrm{ACTH}_{1-24}(0.5 \mathrm{mg} / \mathrm{kg}$, iv) evoked a lower corticosterone response in older (18-mo and 24-mo old) that in the younger (2-mo and 8-mo old) groups of rats.

- Mastorakos et al., [446] presented evidence that basal plasma corticosterone levels were similar in young (3-4 mo) and old (24 mo) female Fischer 344/N rats. Immobilization resulted in dramatic increases in corticosterone levels in both age groups. Furthermore, post-immobilization plasma corticosterone levels were found to be significantly higher in young as compared to old rats.

- Mulchahey et al., [447] reported that basal corticosterone levels in aged (24 mo) rats were significantly elevated at both the AM (0700-0800 h) and PM (1800-1900 h) time points as compared to young $(4 \mathrm{mo})$ rats.

- The work of Silverstein et al., [448] demonstrated that stress significantly increased plasma corticosterone levels by $928 \%, 270 \%$ and $665 \%$ in $7-, 16-$ and 23-month-old rats, respectively. Furthermore, plasma corticosterone was increased by $174 \%$ in 23 -month-old compared to 7 -month-old young rats in response to stress. In addition, basal corticosterone levels were robustly increased in 16-month and 23-month old rats as compared to 7-month old rats.

\section{Fisher 344/Brown-Norway F1 hybrid Rats (F344/BN F1 hybrid rats)}

- The Taglialatela et al., [449] reported significant increases in basal corticosterone levels in 18- and 30-mo old F344/BN F1 hybrid rats relative to young (3-mo) rats.

- Hebda-Bauer et al., [450] utilized young (4-6-mo), old (23-25-mo) and very old (31-mo) F344/BN F1 hybrid rats to examine the effect of aging on circulating corticosterone levels. No age-related differences were noted in baseline, peak-time 2, and clearance of plasma cortiocsterone levels. Very old rats, however, showed significantly lower peak-time 1 corticosterone levels than the young animals (4-6-mo).

- The authors employed young (3-mo), middle-aged (15-mo) and aged (30-mo) F344/Brown-Norway hybrid rats in their studies [451]. They determined the effect of age on plasma corticosterone levels in response to 3 stressors: restraint, spatial novelty and hypoxia. Compared to young (3-mo) and middleaged (15-mo), aged-rats (30-mo) exhibited elevated corticosterone secretion in response to spatial novelty, but not in response to restraint or hypoxia. In contrast, middle-aged responded to chronic stress with increased corticosterone secretion in following hypoxia but not novelty.

- The Kascknow et al., [452] examined corticosterone responses in 3-, 15-, and 30-mo old F344/BN F1 hybrid rats. Basal plasma corticosterone levels did not change with age. Similarly, corticosterone response to restraint stress was also unaffected by the advancing age. However, at $8 \mathrm{~h}$ after a dexamethasone challenge, corticosterone response in 30-mo old rats was significantly lower from that of the 3-mo old rats.

- Young (4-mo), middle-aged (12-mo) and aged (24-mo) F344 rats and aged (24-mo) and aged F344/BN F1 hybrids were used here [453]. Significantly higher plasma corticosterone levels were noted in aged (24-mo) F344 rats as compared to 4- and 12-mo old F344 rats. Likewise, corticosterone levels in 30mo old F344/BN rats were significantly higher than cortiocsterone levels in 4-mo old F344 rats. 


\begin{abstract}
Hooded Rats
- Spencer and McEwen [454] showed that there was no difference in basal plasma corticosterone levels between young (2-3-months) and aged male (2223-months) hooded rats.
\end{abstract}

\title{
Long-Evans (LE) Rats
}

- Hess and Riegle [455] found no change in basal corticosterone levels in young (4-mo) female vs old (25-mo) female (Long-Evans) rats and young (6-mo) vs old (22-mo) male rats. However, both old female and male rats secreted significantly less corticosterone in response to either ACTH treatment or ether stress compared to respective young (control) animals.

- The work of Riegle and Hess [456] and Riegel [457] suggest that the ability of aged (22-32-mo) male and female rats (Long-Evans) to a negative feedback inhibition of the hypothalamic-pituitary axis is significantly impaired as compared to young (4-6-mo) adult animals.

- Meaney et al., $[458,459]$ reported elevated corticosterone levels in 16- and 24-mo old male Long-Evans rats as compared to young (3-mo) and adult (8mo) rats. They also showed a tendency for increased hypothalamic-pituitary-adrenal activity (i.e., blunted feedback inhibition of HPA).

- Issa et al., [460] demonstrated that basal corticosterone levels were significantly higher in cognitively impaired (AI) 23-27 month old male Long-Evans rats than those of cognitively unimpaired (AU) 23-27 month old rats or control (6-mo) animals. Evaluation of stress-induced changes in HPA activity showed that: a) basal pre-stress corticosterone levels were significantly higher in the AI animals; b) there were no group differences in the peak levels of corticosterone attained during stress; and c) AI animals had significantly higher plasma corticosterone levels at each point following the termination of the stressor.

- Rakotondrazafy and Brudieux [461] reported that plasma aldosterone incremental response to angiotensin II was significantly lower in aged (28-32-mo) female Long-Evans rats than in adult (8-10-mo) rats.

- Brudieux et al., [462] examined age-related changes in plasma corticosterone and aldosterone responses to exogenous corticotrophin-releasing hormone $(\mathrm{CRH})$ in female Long-Evans rats. Basal plasma corticosterone and aldosterone levels did not differ between young adult (7-9-mo) and aged (30-35-mo) rats. Treatment with CRH markedly increased plasma levels of corticosterone and aldosterone with similar kinetics, but incremental responses at each time points in old as compared to adult rats.

- Ait-Chaoui et al., [463] observed no age-related changes in basal corticosterone and aldosterone levels in both male and female Long-Evans rats. Furthermore, the authors reported a blunting of corticosteroid (corticosterone and aldosterone) to ACTH in aged male/female (25-31-mo) rats as compared to young male (3-4-mo)/female (4-5-mo) or adult female (12-14-mo) rats.

- Bizon et al., [464] reported finding no differences in either basal or peak plasma corticosterone levels were observed between young (6-mo) or aged (2728-mo) male Long-Evans rats.

\section{Sprgue-Dawley (SD) Rats}

- Lewis and Wexler [465] observed elevated corticosterone levels in middle-aged (15-18-mo) rats versus young (3-4-mo) rats.

- Britton et al., [466] reported a 75\% decline in circulating corticosterone levels as rats aged from 2-mo to 24-mo.

- Tang and Phillips [467] found no age-related differences in either basal or stress-stimulated corticosterone levels.

- DeKosky et al., [468] measured serum corticosterone levels at three time points in the diurnal cycle (08:00, 18:00, and 23:30 h) using young adults (3-5$\mathrm{mo}$ ), middle-aged (14-16-mo), and aged (26-28-mo) rats. In aged animals, serum corticosterone levels at both 18:00 h and 23:30 h were elevated as compared to young rats with most dramatic aging noted at 23:30 $\mathrm{h}$. Moreover, these high levels persisted for a longer time.

- Scaccianoce et al., [469] observed higher circulating levels of corticosterone in aged (25-mo) relative to young (3-mo) rats.

- Foreman et al., [470] provided data showing elevated corticosterone levels in aged (23-mo) compared to young (3-mo) rats. In addition, it was reported that the magnitude of the stress-stimulated corticosterone levels were significantly higher than of similarly treated young animals.

- Terrazino et al., [471] reported higher basal corticosterone levels in old (24-mo) as compared to young (3-mo) rats ( $<<0.01)$. In contrast, decreased corticosterone secretion in old rats was noted in response to LPS stimulation.

- Studies by Núñez et al., [472] revealed elevated basal corticosterone levels in old female (19-22-mo) compared to young (4-6-mo) female rats. However, isolation stress-induced increases in corticosterone levels were similar between young and old rats. In contrast, stress-stimulated corticosterone levels declined more rapidly in young than aged rats following the cessation of isolation stress.

- Lo et al., [473] demonstrated that plasma corticosterone levels were significantly increased in middle-aged (12-mo) and aged (22-24-mo) as compared to young (3-mo) or young mature (6-mo) rats. However, no age-related differences in ACTH stimulation of plasma corticosterone levels were noted among the four groups. Interestingly, two hours after ACTH treatment, plasma corticosterone levels were relatively elevated in old rats compared to young mature rats. Montaron et al., [474] reported an age-related increase in basal plasma corticosterone levels [i.e., young (3-mo) or young mature (14-mo) vs old (21-26mo). However, no aging effect on plasma corticosterone levels was detected when animals were subjected to restraint stress.

\section{Wistar Rats}

- Korte et al., [475] reported that basal plasma corticosterone levels were slightly higher in the aged rats (24 mo) compared to young (3-mo) controls, but the differences were not statistically significant. Both young and old rats showed similar increases in plasma corticosterone levels in response to a single foot shock. Interestingly, one day after shock, the plasma corticosterone levels were reported to be significantly higher than that of controls. On the other hand, no significant differences were noted in the plasma corticosterone levels of young and old rats when challenged with the conditioned defensive burying $(\mathrm{CDB})$ test.

- Yau et al., [476] provided evidence that the basal plasma corticosterone levels were unaffected in aged rats (18-24 mo) as compared to young (7-months) rats.

- Mizuno et al., [477] reported that in aged rats (23-24 mo), basal concentrations of corticosterone were significantly elevated than that in the young (3-4 mo) rats. In young rats, but not in old rats, plasma corticosterone levels were increased in response to stress.

- Bazhanova et al., [478] reported that young (3-6 mo) and old (28-mo) rats had similar levels of basal corticosterone levels. Furthermore, it was noted that stress-induced corticosterone levels also did not change with age.

- Descamps and Cespuglio [479] showed that immobilization stress led to greatly increased plasma corticosterone levels in both young (3-mo) and old (24-mo) rats, although aging had no effect on such responses.

- Garrido et al., [480] provided evidence that the basal levels of total plasma corticosterone measured in blood samples were not different between young (6-mo) and aged (27-mo) rats. Restraint stress significantly increased plasma corticosterone levels in both young and old rats, although the average increase in corticosterone levels in response to stress was significantly higher in old rats.

\section{BALB/c Mice}

- Buchanan et al., [481] examined the effect of repeated stress on plasma corticosterone levels in adult (3-5 months) and aged (22-24 months) male $\mathrm{BALB} / \mathrm{c}$ mice. It was reported that aged-mice had higher levels of basal plasma corticosterone compared to adult mice. They also showed that in adult mice, plasma corticosterone increased to a greater extent with each successive stress session, whereas in aged mice, two stress sessions produced the maximum increase in corticosterone. 
Table 4 Contd.....

\section{C57BL/6 Mice}

- Padgett et al., [482] showed that restraint stress caused conparable increases in circulating plasma corticosterone levels in control (3-mo) and aged (22mo) male C57BL/6 mice, but old mice required a longer time to attain baseline plasma corticosterone levels following the removal of a stressor.

- Rosenthal and Morley [483] provided data showing that aging has no significant effect on plasma corticosterone levels, i.e., plasma corticosterone levels were similar in adult (10-mo) and aged (27-mo) male C57Bl/6 Nnia mice both under basal condition and in response to CRF stimulation.

- Studies by Waziers et al., [484] demonstrated that plasma corticosterone levels were significantly higher in young control (2-mo) as compared to aged.

- Park et al., [485], reported no age-related alteration in plasma corticosterone levels in female C57BL/6J mice both under basal condition and in response to extended restraint stress. For these studies mature adult control (7.5-mo) and aged (22-mo) C57BL/6J female mice were employed.

- Dalm et al., [486] employed 3-, 9-, and 16-month old C57BL/6J mice to examine the age-related changes in hypothalamic-pituitary-adrenal (HPA) activity. The highest AUC values over $24 \mathrm{~h}$ periods were shown by 9 -months old mice as compared to 3 -months and 16 -months old mice. The three age groups showed a distinct circadian pattern; during the light period, 9-month old mice secreted highest levels of corticosterone followed by 3 - and 16-months old mice. The corticosterone secretion rates during the dark phase were not impacted by aging.

\section{C3B10RF $_{1}$ Hybrid Strain of Mice}

- Harris et al., [487] found no age-related changes in plasma corticosterone levels in the long-lived C3B10RF $\mathrm{C}_{1}$ hybrid strain mice. These studies employed 7-, 17- and 29-month old female mice.

\section{CF-1 Male Mice}

- Thurmond and Heishman [488] assessed the secreted corticosterone levels in young (3-mo) and aged (30-mo) CF-1 male mice after cold swim stress. They showed that circulating levels of corticosterone increased to a greater extent in young than aged CF-1 mice.

levels are high due to their synthesis by the fetal adrenal gland. However, DHEA(S) levels drop rapidly as a result of fetal zone atrophy and its disappearance in the first year of life [320,321,323-325]. During childhood, DHEA(S) concentrations remain low through early childhood, but by about 6-7 years of age (with the development of ZR cells in the adrenal cortex), the plasma DHEA(S) concentrations begin to rise and about 2 years before the onset of puberty, there is a dramatic increase in $\operatorname{DHEA}(\mathrm{S})$ secretion, termed the 'adrenarche' [316,317,321]. The plasma levels of DHEA(S) peak at approximately 20 years of age and decline progressively after the age of 25 [318] to $5-10 \%$ of young adult (peak) levels peak values $[3,6]$ by age $70-80$. In general, the age-related decline in DHEA(S) levels shows high interindividual variability and seems to be associated with a loss of zona reticularis cells and/or impairment of their function $[318,325]$. This phenomenon is referred to as adrenopause, and it occurs in both men and women with a gradual pace at similar ages.

\section{Non-human Primates}

Besides humans, the fetal adrenal gland and adult zona reticularis (ZR) of non-human primates also secrete $\mathrm{mg}$ quantities of DHEA(S) [319,321,326]. Although various non-human primates show some degree of age-associated secretion pattern in DHEA(S), until now none of the nonhuman primates have been identified that faithfully duplicate the human adrenal secretion pattern covering all three life stages (i.e., fetal zone or FZ, adrenarche, and senescence) $[319,321,326]$. However, based on the limited morphological, biochemical, and endocrine data, however, it appears that the marmoset simulates the human pattern of FZ, the chimpanzee the human adrenarche, and the Rhesus macaque or Rhesus monkey and baboons the human mature ZR function that progressively declines with senescence $[319,321$, 326].

\section{Rodents and Other Mammals}

In contrast to humans and non-human primates, rodent adrenals lack P450c17, and hence cannot synthesize DHEA [327]. Because of the P450c17 deficiency, circulating levels of DHEA and its sulfated form, DHEAS, are several orders of magnitude lower than in humans. Furthermore, no agerelated changes in plasma DHEA levels have been documented in rodents [328]. Likewise, studies by Cutler et al suggest that circulating concentrations of DHEA(S) remain low throughout life in most mammals including the guinea pig, hamster, rabbit, dog, sheep, pig, goat, horse, and cow [329].

\section{OXIDATIVE STRESS AND AGE-RELATED DECLINE IN STEROIDOGENESIS}

The extensive evidence as presented above indicates that aging in humans and experimental animal models is associated with a general decline in steroid hormone production. Work over the years from this laboratory has shown that the basic problem, at least in aging rats, is that adequate amounts of cholesterol are not available to adrenal (adrenocortical cells) and testis (Leydig cells) for the first step in steroid biosynthesis (i.e., conversion of cholesterol to pregnenolone by the inner mitochondrial membrane-associated side-chain cleavage enzyme system, $\mathrm{P} 450_{\text {scc }}$ [also designated as CYP11A1]) $[25,53,58,66,76,90]$. Questions now center on the nature of this defect. It appears that the uptake of lipoprotein-derived cholesterol esters in the adrenal of aging rats is entirely normal and ample [304,305], and that overall, the accumulated stores of steroid precursor, cholesterol in both adrenocortical cells and Leydig cells from aging animals is more than adequate $[183,298]$ - yet the mitochondria of the steroidogenic cells of these animals do not receive adequate cholesterol substrate.

A substantial body of evidence has accumulated over the last few years indicating that levels of both StAR and PBR/TSPO (the two important intracellular molecules that assist in mediating the cholesterol transport process) are decreased in aging rats-linking an alteration in sterol transfer and transport proteins with the age-related defect in steroidogenesis. When these issues were explored further, it became evident that increased ROS production (primarily from impaired anti-oxidant defense systems) leads to changes in expression of sterol transfer proteins (StAR, StAR-related proteins [StarDs] and PBR/TSPO] in steroidogenic tissues of 
aged animals, and downstream, this leads to a reduction in cholesterol transfer to mitochondria sites where cholesterol side chain cleavage takes place. In the following sections, we summarize the impact of aging-induced excessive ROS generation and ensuing excessive oxidative stress on the events connected with the cholesterol transport to mitochondria for steroid hormone production.

\section{Theories of Aging}

Physiologically aging is an extremely complex, multifactorial process, affecting a myriad of genetic, biochemical, and metabolic processes. Although, numerous aging theories have been proposed to explain mechanisms of aging [330], no theory has been more lasting in this regard than that known as the "free radical theory of aging," in which damage by free radicals (reactive oxygen species [ROS]) is deemed critical in determination of life span [331-333]. This theory proposed in 1956 by the Denham Harman [334] states that free radicals, especially ROS formed as by-products of normal metabolic processes, cause oxidative damage to macromolecules, whose accumulation causes cellular dysfunction, and this ultimately determines the lifespan of an organism $[335,336]$.

Over time, the free radical theory has been further refined; first it was modified to become the "oxidative stress theory" of aging to reflect the fact that oxygen species such as peroxides and aldehydes, which do not fall under the category of free radicals, also play a role in oxidative damage to cells [337]. Later with the realization that mitochondria are at the same time major sources and targets of ROS, the theory was renamed as the "mitochondrial theory of aging" $[331,332,335,337,339]$. According to this theory of aging, ROS produced as by-products of the mitochondrial oxidative respiratory chain damage mitochondrial macromolecules, especially mitochondrial DNA (mtDNA). As a result, an accumulation of mtDNA mutations leads to production of defective mitochondrial respiration, further increasing ROS generation and oxidative damage. It is also suggested that accumulation of oxidant-induced somatic mutations alter the mitochondrial respiratory complex function leading to increased ROS production and further damage to mtDNA as well as other macromolecules [340,341]. This "vicious cycle" of ROS generation and concomitant oxidative damage to macromolecules is suggested as the principal determinant of mammalian lifespan. Over the past few decades a significant amount of correlative evidence has been accumulated in support of the mitochondrial theory of aging including studies that show an increase in ROS generation with age, the age-related increase in oxidative damage to DNA including mtDNA, lipids, and proteins, increased mtDNA deletions and mitochondrial dysfunction with age [338,340].

In recent years, however, the use of transgenic and knockout mouse models with altered expression of antioxidant enzymes and mutant mouse models that have been genetically modified to increase mitochondrial deletions or mutations (Poly ${ }^{D 257 A / D 257 A}$ mutant mice) to directly test the validity of the mitochondrial theory of aging have yielded inconsistence results [337,342-346]. Moreover, in some instances, the data obtained failed to directly support a direct role for mitochondrial oxidative stress or oxidative stress in the determination of life span in mice and also did not support the overall free radical theory of aging [337,342-346]. Although, these various findings are somewhat disappointing, more recent mechanistic studies, however, have clearly implicated the mitochondrial free radical damage and impaired mitochondrial function as being a central contributor to the pathophysiology of aging [347-349]. One prevailing view is that mitochondria influence longevity not only through increased production of ROS and ensuing oxidative damage but also via a stress (ROS)-evoked signal that acts in a cell-non-autonomous manner to regulate mitochondrial protein homeostasis [347,348]. The other studies emphasize a link between excessive ROS production and the functional efficacy of insulin signaling, which are based on the epigenetic oxidative redox shift (EORS) theory of aging [349]. According to EORS, which unifies the free radical and insulin signaling theories, sedentary behavior associated with age triggers an oxidizing redox shift, enhanced ROS generation, reduced mitochondrial turnover and impaired mitochondrial function [349], culminating in further accelerated aging.

\section{Aging and Excessive Oxidative Stress}

Based on extensive in vivo and in vitro studies, it now appears that senescence is associated with increased oxidant generation, a decline in the robustness of cellular defenses and repair, and an accumulation of the end products of the oxidative damage [331,336,339-354]. In general, the three main classes of biological macromolecules (lipids, nucleic acids and proteins) are susceptible to free radical attack and suffer oxidative damage in vivo [331,336,339-354]. Because cellular membranes house the production of these radicals, membrane lipid peroxidation is now regarded as the major process that produces ROS damage during aging [354,355]. This idea is reinforced by the fact that lipid peroxidation increases with age $[331,336]$ and that oxidized lipid residues are major components of lipofucsin, the fluorescent pigment that accumulates with age in most tissues [331].

The risk of lipid peroxidation is especially high for steroidogenic cells, which use molecular oxygen for steroid biosynthesis $[356,357]$ in addition to a more standard cell function [353-355,358]. Cytochrome P450 enzymes of the steroidogenic pathway use molecular oxygen to hydroxylate substrates. As this occurs, ROS such as superoxide anions, hydrogen peroxide, hydroxyradicals and other oxygen free radicals can also be formed as a result of electron leakage or by interaction of the P450 hydroxylases with steroid products (or pseudosubstrates) [356-361]. These oxy-radicals combined with a high content of target substrates for ROS (such as polyunsaturated fatty acids in the adrenal gland and gonads) exaggerate the potential of oxidative changes leading to cell damage and death. Because lipid peroxidation involving membranes could affect membrane composition, structure, fluidity and function (e.g. the activation of membrane proteins like receptors, ion channels, participants of signal transduction pathways, transport proteins and membrane associated enzymes [362-366]), and virtually every event associated with cholesterol processing and steroidogenesis is dependent on the integrity of cell membranes [1$6,25,26,53,81,90,367-369]$, the likelihood of steroidogenesis being adversely affected is quite high. As a result, steroidogenic cells, like other mammalian cells, are well equipped 
with antioxidant systems to combat free radicals [370-375]. These antioxidant systems are comprised of 1) low molecular weight agents such as vitamin E (atocopherol), vitamin C (ascorbic acid), reduced glutathione (GSH), carotenoids, flavonoids, uric acid, bilirubin, and lipoic acid; 2) iron and copper sequestering proteins such as transferrin, lactoferrin, hemopexin, albumin, and ceruloplasmin; 3) antioxidant enzymes such as superoxide dismutase $(\mathrm{Cu}, \mathrm{Zn}-\mathrm{SOD}, \mathrm{Mn}-$ SOD), glutathione peroxidases (e.g., cytosolic glutathione peroxidase [cGPX], phospholipid hydroperoxidase glutathione peroxidase [PHGPX], plasma glutathione peroxidase [pGPX]), catalase, heme oxygenase, and thioredoxin reductase (TR); and 4) accessory antioxidant proteins such as thioredoxins, glutaredoxins, and peroxyredoxins [331,350353,376-381].

\section{Oxidative Damage and Oxidant-sensitive Transcription Factors}

Indeed, this laboratory has shown that adrenals from young rats show the least endogenous lipid peroxidation and the highest levels of resistance to pro-oxidant-induced oxidative damage of the various tissues examined, and show exceedingly high levels of tissue antioxidants [372]. Despite this, aging leads to many oxidative changes both in the adrenocortical and the testicular Leydig cells [372,374]. These are linked, with time, to a dramatic reduction in the normally protective antioxidant defense system, thus, leading to excessive oxidative stress, and, we believe, ultimately to the decline of steroid production in the aging animals, i.e., the increase in lipid peroxidation in steroidogenic tissues may be the underlying cause of the age-related decrease in corticosterone/testosterone synthesis. It is unclear why steroidogenic cells do not respond to this oxidant balance by simply modulating the expression of antioxidant enzymes [372,374], oxidant-sensitive transcription factors, $\mathrm{AP}-1$ and $\mathrm{NF}-\mathrm{\kappa B}$ [353,358,382-385] and other stress inducible cytoprotective genes invoking cellular protective mechanisms [386]. We speculate that up-regulation does not occur in the aging animals because the continuous oxidant burden likely overwhelms the cells, leading to the failure of cellular transcriptional/translational machinery and, thus, the function of various proteins involved in the transport of cholesterol to the mitochondrial sites of P450scc. Experimental evidence that this is the case comes from earlier reports from our laboratory showing that the expression of oxidant-sensitive transcription factors, the activator protein-1 (AP-1) and nuclear factor $\kappa \mathrm{B}(\mathrm{NF}-\mathrm{\kappa B})$ are both substantially reduced in adrenal extracts from aging rats [387,388].

\section{AP-1 Transcription Factor}

The transcription factor AP-1 mediates gene regulation in response to a broad range of physiological and pathological stimuli, including cytokines, growth factors, ROS, infection and other stress signals as well as oncogenic stimuli [353,385,389-394]. In addition, steroid producing tissues are thought to require AP-1 for the regulation of steroidogenesis [387,385-400]. AP-1 transcription factors are homo- and hetero-dimers of Jun (c-Jun, JunB and JunD), Fos (c-Fos, FosB, FosB splice variants FosB2 and DeltaFosB2 and Fra-1 and Fra-2) Jun dimerization partner (JDP1 and JDP2) and the closely related activating transcription factor (ATFa, ATF2, LRF1/ATF3, B-ATF) family of proteins characterized by basic region and leucine-zipper domains [353,385,389-394]. In addition, some of the Maf proteins ( $\mathrm{v}$ Maf, c-Maf and Nrl) can heterodimerize with c-Junior c-Fos, whereas other Maf related proteins, including MafB, MafF, MafG and MafK, heterodimerize with c-Fos but not with cJun. While Jun proteins can themselves form stable homodimers, Fos family members are not able to form homodimers, but homodimerize with Jun partners, giving rise to various trans-activating or trans-repressing complexes with different biochemical properties. Together, all these proteins form the group of AP-1 proteins that after dimerization bind to the AP-1 DNA recognition elements $\left(5^{\prime}-\mathrm{TGA}^{\mathrm{G}} / \mathrm{C}\right.$ TCA-3'), also known as 12-O-tetradecanoylphorbol-13 (TPA)-response element (TRE) in the promoter and enhancer regions of the target genes [389-391,393,394].

Members of the ATF family of proteins can form homodimers or heterodimers with AP-1 proteins (predominantly with Jun proteins) that preferentially bind to cAMPresponsive elements (CRE, 5'-TGACGTCA-3'). AP-1 activity is regulated at various levels, including transcriptional and post-transcriptional mechanisms leading to increased AP-1 expression and post-translational modifications, such as phosphorylation, post-translational processing and turnover or pre-existing or newly synthesized AP-1 subunits and oxidation/reduction, altering DNA binding affinity and transactivation potential [390,392-394,401-405]. Since DNA binding affinity and transactivation potential are different for the various proteins, AP-1 activity is also determined by its composition [390,393,403,405]. Thus, the extent of transcriptional activation or repression conferred upon AP-1 responsive genes depends on post-translational modifications, selective dimerization between different family members, and protein-protein interactions with other regulatory molecules. AP-1 function is also cell type specific [390,393,403,405].

Our own studies demonstrate that the expression of AP-1 constituent proteins (Fos and Jun family of proteins) are considerably reduced in the adrenal extracts of 24-month old rats , and that adrenal expression of JunB (normally considered a repressor of transcription, a cell proliferation inhibitor, a senescence inducer and tumor suppressor [406-410]), is greatly increased [387]. All the AP-1 Fos/Jun family of proteins in adrenal extracts are dramatically activated by lipopolysaccharide (LPS) (a pro-oxidant stressor), as anticipated for agents regulating oxidative stress events, but significantly activation occurs in adrenal extracts of aging (24mo-old rats) compared to that of 5-mo-old mature rats [387].

\section{Aging and p38 Subfamily of MAP Kinases}

The p38 subfamily of MAP kinases consists of 4 members, p38 $\alpha, \mathrm{p} 38 \beta$, p38 $\gamma$ and p38 MAPKs, which share high sequence homology and a signature TGY, where T, G and Y are threonine, glycine and tyrosine, respectively [412-415]. Phosphorylation of both the threonine and tyrosine within this signature sequence is required for $\mathrm{p} 38$ MAPK activation. Phosphorylation of p38 MAPKs via a signaling cascade involving MAPK kinases [MKK3/MKK6] is responsible for phosphorylation of $\mathrm{p} 38 \mathrm{MAPK} \alpha, \beta, \gamma$, and $\delta$, and MAPK 
kinase kinases [MAPKKKs] that phosphorylate and activate MKK3/MKK6. The activated [phosphorylated] form of $\mathrm{p} 38$ MAPK phosphorylates a large number of transcription factors including the NFAT, p53, MEF2, and AP-1 family of proteins such as ATF2, c-Jun, JunB, and c-Fos).

Our recent Western blot analyses data indicated that the levels of active (phosphorylated) form of the p38 MAP kinase (p38 MAPK), in adrenal [411] and Leydig cell lysates (unpublished observation) were substantially increased with aging. The follow-up studies demostrtaed that exposure of Y1-BS1 mouse adrenocortical and the MLTC-1 mouse to various oxidative stressors preferentially stimulated p38 MAPK activity, but at the same time inhibited steroid production [416] and caused down regulation of AP-1 activity (unpublished observation). In addition, recently completed studies with the use of active (wild-type) and dominant negative (dn) cDNA constructs of the p38 MAPK signaling pathways (e.g. p38 MAPK $\alpha$ and MKK6) suggest that p38 MAPK is a negative regulator of the functional expression of AP-1 in steroid producing model cell lines.

Thus, it appears that aging in the rat adrenal [372] and testicular Leydig cells [374] is linked to a reduction in both enzymatic and non-enzymatic components of a cellular natural defense system against oxidative damage, as well as loss in the expression of major AP-1 transcription factor. Under normal stress conditions the expression of major AP-1 constituent proteins $[382,402]$ is up-regulated, but in the aging adrenal, the only transcription factor whose expression is increased (rather than decreased) is Jun B [387], a putative repressor of AP-1 function [406-410]. These events suggest that cellular defense against oxidative stress is reduced in aging animals, and the potential impact of this on steroidogenesis becomes even more clear when one realizes that promoter regions of StarD1/StAR and PBR/TSPO genes, the two intracellular molecules which assist in mediating the cholesterol transport process [53,58,59,66,76,81,417-419], contain an AP-1 response element [420,421], and that the proximal AP-1 site in the StarD1/StAR promoter plays a pivotal role in regulating StarD1/StAR gene transcription [420].

It is well known that the acute, rate-limiting step in steroid hormone biosynthesis in steroidogenic tissues is the translocation of cholesterol from the outer mitochondrial membrane (OMM) to the inner mitochondrial membrane (IMM), where it is converted to the pregnenolone by the cholesterol-side chain cleavage enzyme, P450scc (CYP11A1), thus initiating the synthesis of the steroid hormone [1-6]. It can be demonstrated that when hydroxyl analogs of cholesterol [such as 22(R)-, 20 $\alpha-$ or 25hydroxycholesterol, which readily diffuse though cell membranes to the P450scc] are provided to cells, high levels of steroid can be produced even in the absence of hormone stimulation, i.e., it is not the reaction catalyzed by P450scc that is rate limiting, but rather the transport of cholesterol to these sites. The same is true for cells from aging animals. When supplied with freely diffusible cholesterol analog (i.e., hydroxyl cholesterols), adrenocortical and testicular Leydig cells from aging rats are totally competent in producing steroids (corticosterone and testosterone). The "acute" production of steroids is dependent upon a hormone-stimulated, rapidly synthesized, cyclohexamide-sensitive and highly labile protein whose function is to transfer cholesterol from outer to inner mitochondrial membranes [53,61-63]. StarD1/StAR is now identified as a putative acute regulatory protein $[53,58,59,76,90,417,418]$. Recent evidence, however, indicates that StarD1/StAR may also requires participation of a PBR/TSPO multimeric complex in facilitating cholesterol transport from the outer to the inner mitochondrial membrane $[75,90,419]$.

In regard to the apparent critical function of an "acute" regulatory protein in steroidogenesis, it is of interest that expression of both StarD1/StAR and PBR/TSPO is downregulated in the adrenal and Leydig cells of aging rats [422426]. For example, studies from this laboratory have shown an $80 \%$ reduction in StarD1/StAR protein expression of nonstimulated Leydig cells prepared from old Sprague-Dawley rats suggesting that the impaired testosterone production that occurs during aging may involve attenuated StAR expression [422]. Upon stimulation with hCG, Leydig cells from young rats demonstrated a 3-4-fold increase in StAR expression (both protein and mRNA levels), while expression in cells from aging (24-mo-old) rats increased no more that 50-70\%. Likewise, expression of StarD2 and StarD4 is reduced in aging Leydig cells, both under basal and hCG-stimulated conditions [426]. The expression of neither StarD3 nor StarD5 was affected by aging. Also, experiments using adrenals from aging animals show ACTH stimulated StarD1/StAR and PBR/TSPO mRNA expression is dramatically reduced (unpublished observation). At the same time, expression of DBI did not change, nor did the expression of the other putative sterol transfer factors such as SCP2, SAP precursor (GRP-78), VADC1-3 or ANC. The concept that insufficient sterol transfer protein in steroidogenic cells of aging animals explains the age-related impairment in hormone production is strengthened by studies of mutations in humans and the ablation of the StAR gene in mice. Similar to what is observed in aging adrenal and Leydig cells, humans carrying mutations that inactivate StarD1/StAR exhibit markedly reduced gonadal and adrenal steroidogenesis, a condition that leads to excessive accumulation of cholesterol in lipid droplets and a disease named congenital lipoid adrenal hyperplasia [427]. Ablation of the StarD1/StAR gene in mice also results in a phenotype of impaired steroidogenesis and adrenal lipid accumulation [428]. Likewise, deletion of PBR/TSPO results in a greater than $90 \%$ reduction in steroid production and severe impairment in cholesterol transport to mitochondria, both of which can be rescued by reintroduction of the PBR/TSPO [429].

It appears, therefore, that several critical inter-relating factors relevant to steroidogenesis are significantly altered in the aging rat model. These may include expression levels of sterol transfer proteins (such as StarD1/StAR, StAR-related proteins and PBR/TSPO), oxidant sensitive transcription factors (such as AP-1 possibly involved in the inducible expression of sterol transfer protein genes) and other genes responsive to oxidative stress. A significant attenuation in AP-1 expression over time and continual excessive oxidative insult might lead to impaired regulation of StAR gene transcription, decreased expression of other StAR-related cholesterol transfer proteins, and the StAR partner, PBR, and as a result, decreased cholesterol delivery to mitochondria and 
loss of steroidogenesis. It remains to be determined as to how increased ROS formation and ensuing oxidative damage leads to changes in expression of sterol transfer proteins, StAR, StarD proteins and PBR/TSPO in steroidogenic tissues of aged animals, and downstream, this leads to the transfer of less cholesterol to mitochondrial sites where cholesterol side chain cleavage takes place.

\section{CONCLUSION AND PERSPECTIVES}

All steroid hormones are derived from cholesterol, and they are made up of three six-carbon rings, one five carbon ring, and a unique side chain, a basic structure that is characteristic of the cholesterol molecule. They are secreted primarily by three "steroidogenic glands" - the adrenal gland, ovaries and testes and during pregnancy by the placenta. Steroid hormones are classified into five classes namely: estrogens, progestins, androgens, glucocorticoids and mineralocorticoids. Glucocorticoids and mineralocorticoids together are called corticoids, whereas estrogens, progestin and androgens are often referred to as sex steroids. The androgens and estrogens are primarily responsible for the development and maintenance of reproductive function and secondary sex characteristics in the male and female, respectively. Estrogens and progestin are typically linked with the female reproductive functions such as menstrual cycle, ovulation and implantation of the embryo. Mineralocorticoids such as aldosterone help maintain the balance between water and salts in the body, predominantly exerting their effects within the kidney. Glucocorticoids are typically involved in the regulation of lipid, carbohydrate and protein metabolism.

Numerous cross-sectional longitudinal studies conducted during the past four decades or so have established that circulating levels of testosterone decline with advancing age in men, and this decline has been associated with parallel agerelated metabolic and pathophysiological changes such as increased fat mass, decreased muscle and bone mass, frailty, depression, sexual function, osteopenia, and osteoporosis, insulin resistance, diabetes and increased cardiovascular risk. Although there is dysfunction of the hypothalamic-pituitarygonadal (HPG) axis in men, the age-related decline in testosterone levels is most likely to involve direct alterations of testicular Leydig cell function. Likewise, aging of the human ovary also results in a gradual decline in ovarian steroid production, followed by an abrupt and complete cessation of both progesterone and estrogen production at the onset of menopause. Human aging is also associated with alterations in adrenal steroid secretion, a decline in aldosterone secretion and subtle changes in cortisol production. Also, the adrenal androgens, DHEA and DHEAS decline more dramatically with age in a situation similar to menopause, and these decreases are considered to aggravate some age-related diseases.

Similar to humans, advancing age in experimental animals, particularly rats, is also associated with profound changes in the synthesis and secretion of steroid hormones. With corticosterone or testosterone, one does not always notice a decline in circulating levels due to various compensatory mechanisms of the organism, decreased disposal rates of the hormones, or change in binding proteins, etc? But when specifically challenged in vitro, isolated adrenocortical cells or Leydig cells of older rats in several different strains show significantly less steroidogenic response to trophic hormone stimulation than do cells from young animals. Overall, these changes appear not to be a function of reduced tropic hormone receptor signaling or a defect in the steroid synthesizing, but a change in the ability of aging tissues to mobilize the intracellular cholesterol needed for steroid hormone production. Despite the fact that these accumulate excessive amounts of cholesteryl esters in the form of lipid droplets, it appears they cannot appropriately transport the steroid precursor (i.e., free cholesterol) to mitochondrial sites of the CYP11A1/P450scc enzyme, where the conversion of cholesterol to pregnenolone (the precursor of all steroid hormones) takes place with side chain cleavage. Although various cellular and molecular mechanisms controlling this aging defect have not been definitively identified, considerable evidence from this laboratory points to excessive free radical (ROS) formation and oxidative damage (especially from life-long continued processing of cholesterol for steroid production) to the cell machinery regulating the functional expression of crucial proteins involved in cholesterol transport. The latter include cellular sterol transport proteins (such as StarD1/StAR protein, certain StAR-related [StarD] proteins, and a multimeric protein complex collectively known as the PBR/TSPO complex, which assists in translocation of cholesterol from the OMM to the IMM, where it is converted to pregnenolone by mitochondrial side chain cleavage (CYP11A1/P450scc), as well as interactions between tissue AP-1 transcription factors and p38 MAPK, which appear to regulate the expression of the StarD1StAR protein, and possibly that of PBR/TSPO.

However, very little is known about the underlying molecular mechanisms by which aging-induced excessive oxidative stress alters the functional expression of these critical inter-relating factors relevant to steroidogenesis. Outstanding questions that should be addressed in the future include: (1) a detailed characterization of molecular events that lead to excessive ROS production and oxidative damage; (2) mechanism(s) by which aging-related continual excessive oxidative insults leads to a significant attenuation of AP-1 expression, and consequently, impaired regulation of StarD1/StAR and its partner PBR/TSPO and the relevant StarD proteins; (3) the involvement; and (4) the pathological and physiological roles of p38 MAPK isoforms in mediating age-related excessive oxidative stress-induced alterations in the functional expression of these crucial steroidogenic protein factors. The application of the state-of-the-art molecular, cellular and biochemical approaches, coupled with highthroughput proteomic and lipidomics approaches, may provide valuable insights into these important questions. Moreover, the use of genetically modified mice to modulate (decreased or increased) expression of antioxidant enzymes (e.g., Cu,Zn-SOD, Mn-SOD, catalase, GPX-1 or GPX-4) in a time-dependent manner will be very useful to elucidate in vivo mechanism(s) by which excessive oxidative stress contributes to age-related decline in steroid hormone synthesis and secretion. The use of designer cell lines overexpressing a pair of various combinations of antioxidant enzymes (e.g. 
Mn-SOD/catalase or Mn-SOD/GPX-1 will convert superoxide anions into harmless water) or chronic treatment of old rats with small molecular weight natural or synthetic antioxidants should also yield valuable information. It is likely that future studies along these lines may identify novel targets for the development of new therapies to treat male hypogonadism and other clinical conditions associated with alterations in the level of specific steroid hormones in response to aging.

\section{ABBREVIATIONS}

ACTH

ANC

AP-1

$\mathrm{CEH}$

$\mathrm{C}$

CEs

DEX

CRF

cGPX

CRE

$\mathrm{Cu}, \mathrm{Zn}-\mathrm{SOD}$

DHEA

DHT

FSH

G

GnRH

GSH

$\mathrm{H}$

hCG

HDL

IMM

LDL

LH

\section{$=$ Adrenocorticotropic hormone}

$=\quad 30-\mathrm{kDa}$ adenine nucleotide translocator

$=$ Activator protein- 1

$=$ Cholesteryl ester hydroxylase

$=\quad$ Adenylate cyclase

$=\quad$ Cholesteryl esters

$=$ Dexamethasone

$=$ Corticotrophin-releasing factor

$=$ cytosolic glutathione peroxidase

$=$ cAMP-responsive elements

$=\mathrm{Cu}, \mathrm{Zn}$-superoxide dismutase

$=$ Dehydroepiandrosterone

$=$ Dihydrotestosterone

$=$ Follicle-stimulating hormone

$=\mathrm{G}$ proteins (guanine nucleotide-binding proteins)

$=$ Gonadotropin-releasing hormone

$=$ Reduced glutathione

$=$ Tropic hormone $(\mathrm{ACTH}$, LH, FSH)

$=$ human chorionic gonadotropin

$=\quad$ High-density lipoprotein

$=$ Inner mitochondrial membrane

$=\quad$ Low-density lipoprotein

$=\quad$ Luteinizing hormone
TR

TRE

TSPO

MKK3

MKK6

Mn-SOD

MT

mtDNA

$\mathrm{NF}-\kappa \mathrm{B}$

OMM

PBR

$\mathrm{P} 450 \mathrm{scc}$

PHGPX

pGPX

PKA

PRAX-1

$\mathrm{R}$

ROS

SAP

$\mathrm{SCP}_{2}$

SHBG

StAR

StAR-related lipid transfer =

StarD2

TPA

VDAC $=\quad$ Mitogen activated protein kinase kinase 3

$=\quad$ Mitogen activated protein kinase kinase 6

$=$ Mn-superoxide dismutase

$=$ Menopausal transition

$=$ mitochondrial DNA

$=\quad$ Nuclear factor $\kappa \mathrm{B}$

$=$ Outer mitochondrial membrane

$=$ Peripheral-type benzodiazepine receptor

$=$ Side-chain cleavage (scc) cytochrome P450

$=$ Phospholipid hydroperoxide glutathione peroxidase

$=$ plasma glutathione peroxidase

$=\quad$ AMP-dependent protein kinase or protein kinase A

$=$ PBR-associated protein1

$=$ Tropic hormone $(\mathrm{ACTH}$, FSH, and LH) receptors

$=$ Reactive oxygen species

$=$ Steroidogenesis activator polypeptide

$=\quad$ Sterol carrier protein $_{2}$

$=$ Sex-hormone-binding globulin

$=$ Steroidogenic acute regulatory protein

$=$ (START) domain containing protein

$=$ Steroidogenic acute regulatory proteinrelated transfer (START) domain protein 2

$=12-O-$ tetradecanoylphorbol-13acetate

$=$ Thioredoxin reductase

$=$ Responsive element

$=$ Mitochondrial translocator protein

$=34 \quad \mathrm{kDa} \quad$ voltagedependent anion 


\section{CONFLICT OF INTEREST}

The authors have no conflict of interest to report.

\section{ACKNOWLEDGEMENTS}

This work was supported by the Office of Research and Development, Medical Service, Department of Veterans Affairs, and a grant (HL033881) from the National Institutes of Health to Dr. Azhar.

\section{REFERENCES}

[1] White PC. Genetic diseases of steroid metabolism. Vitam Horm 1994; 49: 131-95.

[2] Conley AJ, Bird IM. The role of cytochrome P450 17 $\alpha$ hydroxylase and $3 \beta$-hydroxysteroid dehydrogenase in the integration of gonadal and adrenal steroidogenesis via the $\Delta^{5}$ and $\Delta^{4}$ pathways of steroidogenesis in mammals. Biol Reprod 1997; 56: 78999.

[3] Payne AH, Hales DB. Overview of steroidogenic enzymes in the pathway from cholesterol to active steroid hormones. Endocr Rev 2004; 25: 947-70.

[4] Ghayee HK, Auchus RJ. Basic concepts and recent developments in human steroid hormone biosynthesis. Rev Endocr Metab Disord 2007; 8: 289-300.

[5] LaVoie HA, King SR. Transcriptional regulation of steroidogenic genes: STARD1, CYP11A1 and HSD3B. Exp Biol Med (Maywood) 2009; 234: 880-907.

[6] Miller WL, Auchus RJ. The molecular biology, biochemistry, and physiology of human steroidogenesis and its disorders. Endocr Rev 2011; 321: 81-151.

[7] Kallen CB. Steroid hormone synthesis in pregnancy. Obstet Gynecol Clin N Am 2004; 31: 795-816.

[8] Arlt W, Stewart PM. Adrenal corticosteroid biosynthesis, metabolism and action. Endocrinol Metab Clin N Am 2005; 34: 293-313.

[9] Wu FCW. Testicular steroidogenesis and androgen use and abuse. Bailliers Clin Endocrinol Metab 1992; 6: 373-403.

[10] Leung PCK, Armstrong DT. Interactions of steroids and gonadotropins in the control of steroidogenesis in the ovarian follicle. Ann Rev Physiol 1980; 42: 71-82.

[11] Graham JD, Clarke CL. Physiological action of progesterone in target tissues. Endocr Rev 1997; 18: 502-19.

[12] Wierman ME. Sex steroid effects at target tissues: mechanisms of action. Ad Physiol Educ 2007; 31: 26-33.

[13] Deroo BJ, Korach KS. Estrogen receptors and human disease. J Clin Invest 2006; 116: 561-70.

[14] Vasudevan N, Pfaff DW. Membrane-initiated actions of estrogens in neuroendocrinology: Emerging principles. Endocr Rev 2007; 28 : 1-19.

[15] Bagatell CJ, Bremner WJ. Androgens in men-uses and abuses. N Eng J Med 1996; 334: 707-14.

[16] Oettel M. The endocrine pharmacology of testosterone therapy in men. Naturwissenschaften 2004; 91: 66-76.

[17] Takahashi PY, Votruba P, Abu-Rub M, Mielke K, Veldhuis JD. Age attenuates testosterone secretion driven by amplitude-varying pulses of recombinant human luteinizing hormone during acute gonadotrope inhibition in healthy men. J Clin Endocrinol Metab 2007; 92: 3626-32.

[17a] Oury F, Sumara G, Sumara O, et al. Endocrine regulation of male fertility by the skeleton. Cell 2011; 144: 796-809.

[18] Pearce D, Bhargava A, Cole T. Aldosterone: its receptor, target genes, and actions. Vit Horm 2003; 66: 29-76.

[19] Art W, Stewart PM. Adrenal corticosteroid biosynthesis, metabolism, and action. Endocrinol Metab Clin N Am 2005; 34: 293-313.

[20] Lamberts SW, van den Beld AW, van der Lely AJ. The endocrinology of aging. Science 1997; 278: 419-24.

[21] Perry HM III. The endocrinology of aging. Clin Chem 1999; 45: 1369-76.

[22] Chang AM, Halter JB. Aging and insulin secretion. Am J Physiol Endocrinol Metab 2003; 284: E7-12.
[23] Smith RG, Betancourt L, Sun Y. Molecular endocrinology and physiology of the aging central nervous system. Endocr Rev 2005; 26: 203-50.

[24] Russell SJ, Kahn CR. Endocrine regulation of ageing. Nat Rev Mol Cell Biol 2007; 8: 681-91.

[25] Azhar S, Reaven E. Scavenger receptor class BI and selective cholesteryl ester uptake: partners in the regulation of steroidogenesis. Mol Cell Endocrinol 2002; 195: 1-26.

[26] Pedersen RC. Cholesterol biosynthesis, storage, and mobilization in steroidogenic organs. In: Yeagle PL, Ed. Biology of cholesterol. Boca Raton: CRC Press Inc. 1988; pp. 39-69.

[27] Lange Y, Schmit VM, Schreiber JR. Localization and movement of newly synthesized cholesterol in rat ovarian granulosa cells. Endocrinology 1988; 123: 81-6.

[28] Freeman DA. Plasma membrane cholesterol: removal and insertion into the membrane and utilization as substrate for steroidogenesis. Endocrinology 1989; 124: 2527-34.

[29] Pörn MI, Tenhunen J, Slotte JP. Increased steroid secretion in mouse Leydig tumor cells after induction of cholesterol translocation by sphingomyelin degradation. Biochim Biophys Acta 1991; 1093: 7-12.

[30] Goldstein JL, Brown MS. The LDL receptor. Arterioscler Thromb Vasc Biol 2009; 29: 431-8.

[31] Jeon H, Blacklow SC. Structure and physiologic function of the low-density lipoprotein receptor. Annu Rev Biochem 2005; 74: 535-62.

[32] Chang TY, Chang CC, Ohgami N, Yamauchi Y. Cholesterol sensing, trafficking, and esterification. Annu Rev Cell Dev Biol 2006; 22: 129-57.

[33] Azhar S, Leers-Sucheta S, Reaven E. Cholesterol uptake in adrenal and gonadal tissues: the SR-BI and 'selective' pathway connection. Front Biosci 2003; 8: s998-1029.

[34] Rigotti A, Miettinen HE, Krieger M. The role of the high-density lipoprotein receptor SR-BI in the lipid metabolism of endocrine and other tissues. Endocr Rev 2003; 24: 357-87.

[35] Kraemer FB. Adrenal cholesterol utilization. Mol Cell Endocr 2007; 265-266: 42-5.

[36] Morris MD, Chaikoff IL. The origin of cholesterol in liver, small intestine, adrenal gland, and testis of the rat: dietary versus endogenous contributions. J Biol Chem 1959; 234: 1095-7.

[37] Andersen JM, Dietschy JM. Relative importance of high and low density lipoproteins in the regulation of cholesterol synthesis in adrenal gland, ovary and testis of the rat. J Biol Chem 1978; 253:9024-32.

[38] Xie C, Richardson JA, Truly SD, Dietschy JM. Cholesterol substrate pools and steroid hormone levels are normal in the face of mutational inactivation of NCP1 protein. J Lipid Res 2006; 47: 953-63.

[39] Azhar S, Reaven E. Regulation of Leydig cell cholesterol metabolism. In: Hardy MP, Payne AH, Eds. The leydig cell in health and disease. Totowa, NJ: Humana Press Inc. 2007; pp. 135-48.

[40] Carr BR, Parker CR Jr, Ohashi M, MacDonald PC, Simpson ER. Regulation of human fetal testicular secretion of testosterone: lowdensity lipoprotein-cholesterol and cholesterol synthesized de novo as steroid precursor. Am J Obstet Gynecol 1963; 146: 241-7.

[41] Moyle WR, Kong YC, Ramachandran Y. Steroidogenesis and cyclic adenosine 3',5'-monophosphate accumulation in rat adrenal cells: Divergent effects of adrenocorticopin and its $O$-nitrophenyl sulfenyl derivative. J Biol Chem 1973; 248: 2409-17.

[42] Sala GB, Hayashi K, Catt KJ, Dufau ML. Adrenocortropin action in isolated adrenal cells: The intermediate role of cyclic AMP stimulation of corticosterone synthesis. J Biol Chem 1979; 254: 3861-5.

[43] Braley LM, Williams GH. Rat adrenal cell sensitivity to angiotensis II, $\alpha-{ }^{1-24}-\mathrm{ACTH}$, and potassium: a comparative study. Am J Physiol 1977; 233: E402-6.

[44] Fujita K, Aguilera G, Catt KJ. The role of cyclic AMP in aldosterone production by isolated zona glomerulosa cells. J Biol Chem 1979; 254: 8567-74.

[45] Conti M, Harwood JP, Dufau ML, Catt KJ. Effect of gonadotropininduced receptor regulation on biological response in isolated rat luteal cells. J Biol Chem 1977; 252: 8869-74.

[46] Azhar S, Menon KMJ. Receptor-mediated gonadotropin action in the ovary: rat luteal cells preferentially utilize and are acutely dependent upon the plasma lipoprotein-supplied sterols in gonadotro- 
pin-stimulated steroid production. J Biol Chem 1981; 256: 654855.

[47] Knecht M, Amsterdam A, Catt K. The regulatory role of cyclic AMP in hormone-induced granulosa cell differentiation. J Biol Chem 1981; 256:10628-33.

[48] Jones PBC, Welsh TH Jr, Hsueh AJW. Regulation of ovarian progestin production by epidermal growth factor in cultured rat granulosa cells. J Biol Chem 1982; 257: 11268-73

[49] Magoffin DA, Erickson GF. Primary culture of differentiating ovarian androgen-producing cells in defined medium. J Biol Chem 11982; 257: 4507-13.

[50] Morley P, Calaresu FR, Barbe GJ, Armstrong DT. Insulin enhances luteinizing hormone-stimulated steroidogenesis by porcine theca cells. Biol Reprod 1989; 40: 735-43.

[51] Mendelson C, Dufau M, Catt K. Gonadotropin binding and stimulation of cyclic adenosine 3':5'-monophosphate and testosterone production in isolated Leydig cells. J Biol Chem 1975; 250: 881823.

[52] Payne AH, Wong K-L, Vega MM. Differential effects of single and repeated administration of gonadotropins on luteinizing hormone receptors and testosterone synthesis in two populations of Leydig cells. J Biol Chem 1980; 255: 7118-22.

[53] Stocco DM. Intramitochondrial cholesterol transfer. Biochim Biophys Acta 20001486: 184-97.

[54] Garren LD, Gill GN, Masui H, Walton GM. On the mechanism of action of ACTH. Recent Prog Horm Res 1971; 27: 433-78.

[55] Simpson ER, McCarthy JL, Peterson JA. Evidence that the cycloheximide-sensitive site of adrenocorticotropic hormone action is in the mitochondrion: changes in pregnenolone formation, cholesterol content, and the electron paramagnetic resonance spectra of cytochrome P-450. J Biol Chem 1978; 253: 3135-9.

[56] Ohno Y, Yanagibashi K, Yonezawa Y, Ishiwatari S, Matsuba M. A possible role od "steroidogenic factor" in the corticosteroidogenic response to ACTH; effect of ACTH, cycloheximide and aminoglutethimide on the content of cholesterol in the outer and inner mitochondrial membrane of rat adrenal cortex. Endocrinol Jpn 1983; 30: 335-8.

[57] Privalle CT, Crivello JF, Jefcoate CR. Regulation of intramitochondrial cholesterol transfer to side-chain cleavage cytochrome P450 in rat adrenal gland. Proc Natl Acad Sci USA 1983; 80: 702-6.

[58] Stocco DM, Clark BJ. Regulation of the acute production of steroids in steroidogenic cells. Endocr Rev 1996; 17: 221-44.

[59] Christenson LK, Strauss JF III. Steroidogenic acute regulatory protein (StAR) and the intramitochondrial translocation of cholesterol. Biochim Biophys Acta 2000; 1529:175-87.

[60] Sanborn BM, Heindel JJ, Robison GA. The role of cyclic nucleotides in reproductive processes. Annu Rev Physiol 1980; 42: 37-57.

[61] Ferguson JJ Jr. Protein synthesis and adrenocorticotropin responsiveness. J Biol Chem 1963; 238: 2754-9.

[62] Arthur JR, Boyd GS. The effect of protein synthesis on cholesterol side-chain cleavage in the mitochondria of luteinized rat ovaries. Eur J Biochem 1974; 49: 117-27.

[63] Cooke BA, Janszen FHA, Clotscher WF, van der Molen HK. Effect of protein-synthesis inhibitors on testosterone production in rat testis interstitial tissue and Leydig-cell preparations. Biochem J 1975; 150: 413-8.

[64] Pon LA, Orme-Johnson NR. Acute stimulation of steroidogenesis in corpus luteum and adrenal cortex by peptide hormones: rapid induction of a similar protein in both tissues. J Biol Chem 1986; 261 : 6594-9.

[65] Pon LA, Epstein LF, Orme-Johnson MR. Acute cAMP stimulation in Leydig cells: rapid accumulation of a protein similar to that detected in adrenal cortex and corpus luteum. Endocr Res 1986; 12: 429-46.

[66] Manna PR, Stocco DM. Regulation of the steroidogenic acute regulatory protein expression: functional and physiological consequences. Curr Drug Targets Immune Endocr Metabol Disord 2005; 51: 93-108.

[67] Clark BJ, Wells J, King SR, Stocco DM. The purification, cloning, and expression of a novel luteinizing hormone-induced mitochondrial protein in MA-10 mouse Leydig tumor cells: characterization of the steroidogenic acute regulatory protein (StAR). J Biol Chem 1994; 269: 28314-22.
[68] Bose HS, Sugawara T, Straus JF III, Miller WL. The pathophysiology and genetics of congenital lipoid adrenal hyperplasia. N Engl J Med 1996; 335: 1870-8

[69] Caron KM, Soo S-C, Wetsel WC, Stocco DM, Clark BJ, Parker KL. Targeted disruption of the mouse gene encoding steroidogenic acute regulatory protein provides insights into congenital lipoid adrenal hyperplasia. Proc Natl Acad Sci USA 1997; 94: 11540-5.

[70] Kallen CB, Billheimer JT, Summers SA, Stayrook SE, Lewis M, Strauss JF III. Steroidogenic acute regulatory protein (StAR) is a sterol transfer protein. J Biol Chem 1998; 273: 26285-8.

[71] Petrescu AD, Gallegos AM, Okamura Y, Strauss JF III, Schroeder F. Steroidogenic acute regulatory protein binds cholesterol and modulates mitochondrial membrane sterol domain dynamics. J Biol Chem 2001; 276: 36970-82.

[72] Baker BY, Epand RF, Epand RM, Miller W. Cholesterol binding does not predict activity of the steroidogenic acute regulatory protein, StAR. J Biol Chem 2007; 282: 1023-32.

[73] Wang X, Liu Z, Eimeral S, et al. Effect of truncated forms of the steroidogenic acute regulatory protein on intramitochondrial cholesterol transfer. Endocrinology 1998; 139: 3903-12.

[74] Arakane F, Sugawara T, Nishino H, et al. Steroidogenic acute regulatory protein (StAR) retains activity in the absence of its mitochondrial import sequence: implications for the mechanism of StAR action. Proc Natl Acad Sci USA 1996; 93: 13731-6.

[75] Bose HS, Lingappa VR, Miller WL. Rapid regulation of of steroidogenesis by mitochondrial protein import. Nature 2002; 417: 8791.

[76] Miller WL. Steroidogenic acute regulatory protein (StAR), a novel mitochondrial cholesterol transporter. Biochim Biophys Acta 2007; 1771: 663-76.

[77] Soccio RE, Breslow JL. StAR-related lipid transfer (START) proteins: mediators of intracellular lipid metabolism. J Biol Chem 2003; 278: 22183-6.

[78] Soccio RE, Adams RM, Maxwell KN, Breslow JL. Differential gene regulation of StarD4 and StarD5 cholesterol transfer proteins: activation of StarD4 by sterol regulatory element-binding proten-2 and starD5 by endoplasmic reticulum stress. J Biol Chem 2005; 280: 19410-8.

[79] Bose HS, Whittal RM, Ran Y, Bose M, Baker BY, Miller WL. StAR-like activity and molten globule behavior of StARD6, a male germ-line protein. Biochemistry 2008; 47: 2277-88.

[80] Papadopoulos V. Peripheral-type benzodiazepine/Diazepam binding inhibitor receptor: biological role in steroidogenic cell function Endocr Rev 1993; 14: 222-40.

[81] Lacapère J-J, Papadopoulos V. Peripheral-type benzodiazepine receptor: structure and function of a cholesterol-binding protein in steroid and bile acid biosynthesis. Steroids 2003; 68: 569-85.

[82] Krueger KE, Papadopoulos V. Peripheral-type benzodiazepine receptors mediate translocation of cholesterol from outer to inner mitochondrial membrane in adrenocortical cells. J Biol Chem 1990; 265: 15015-22.

[83] Papadopoulos V, Mukhin AG, Costa E, Krueger KE. The peripheral-type benzodiazepine receptor is functionally linked to Leydig cell steroidogenesis. J Biol Chem 1990; 265: 3772-9.

[84] Papadopoulos V, Nowzari FB, Krueger KE. Hormone-stimulated steroidogenesis is coupled to mitochondrial benzodiazepine receptors: tropic hormone action on steroid biosynthesis is inhibited by flunitrazepam. J Biol Chem 1991; 266: 3682-7.

[85] Amsterdam A, Suh BS. An inducible functional peripheral benzodiazepine receptor in mitochondria of steroidogenic granulosa cells. Endocrinology 1991; 128:503-10.

[86] Papadopoulos V, Amri H, Li H, Biujrad N, Vidic B, Garnier M. Targeted disruption of the peripheral-type benzodiazepine receptor gene inhibits steroidogenesis in the R2C Leydig tumor cell line. J Biol Chem 1997; 272: 32129-35.

[87] Hauet T, Yao Z-H, Bose HS, et al. Peripheral-type benzodiazepine receptor-mediated action of steroidogenic acute regulatory protein on cholesterol entry into Leydig cell mitochondria. Mol Endocrinol 2005; 19: 540-54.

[88] Papadopoulos V, Culty JLM. Is there a mitochondrial signaling complex facilitating cholesterol import? Mol Cell Endocrinol 2007; 265-266: 59-64.

[89] West LA, Horvat RD, Roess DA, Barisas BG, Juengel JL, Niswender GD. Steroidogenic acute regulatory protein and periph- 
eral-type benzodiazepine receptor associate at the mitochondrial membrane. Endocrinology 2001; 142: 502-5.

[90] Miller WL. Mechanism of StAR's regulation of mitochondrial cholesterol import. Mol Cell Endocrinol 2007; 265-266: 46-50.

[91] Liu J, Rone MB, Papadopoulos V. Protein-protein interactions mediate mitochondrial cholesterol transport and steroid biosynthesis. J Biol Chem 2006; 281: 38879-93.

[92] Bose M, Whittal RM, Miller W, Bose H. Steroidogenic activity of StAR requires contact with mitochondrial VDAC1 and phosphate Carrier protein. J Biol Chem 2008; 283: 8837-45.

[93] Liu J, Rone MB, Papadopoulos V. Protein:protein interactions mediate mitochondrial cholesterol transport and steroid biosynthesis. J Biol Chem 2006; 281: 38879-93.

[94] Miller WJ. Role of mitochondria in steroidogenesis. Endocr Dev 2011; 20: 1-19.

[95] Hijazi RA, Cunningham GR. Andropause: is androgen replacement therapy indicated for the aging male? Annu Rev Med 2005; 56: 117-37.

[96] Kaufman JM, Vermeulen A. The decline of androgen levels in elderly men and its clinical and therapeutic implications. Endocr Rev 2005; 26: 833-76.

[97] Heller CG, Myers GB. The male climacteric, its symptomatology, diagnosis and treatment. JAMA 1944; 126: 472-7.

[98] Hollander N, Hollander VP. The microdetermination of testosterone in human spermatic vein blood. J Clin Endocrinol Metab 1958; 18: $966-71$.

[99] Coppage WS, Cooner AE. Testosterone in human plasma. N Eng J Med 1965; 273: 902-7.

[100] Gandy HM, Peterson RE. Measurement of testosterone and 17ketosteroids in plasma by the double isotope dilution derivative technique. J Clin Endocrinol Metab 1968; 28: 949-77.

[101] Kent JZ, Acone AB. Plasma androgens and aging. In: Vermeulin A, Exley D, Eds. Androgens in normal and pathological conditions. Amesterdam: Excerpta Medica Foundation 1966; pp. 31-5.

[102] Vermeulen A, Verdonck L, Rubens R. Testosterone secretion and metabolism in male senescence. J Clin Endocrinol Metab 1972; 34 : 730-5.

[103] Harman SM, Tsitouras PD. Reproductive hormones in aging men. I. Measurement of sex steroids, basal luteinizing hormone and Leydig cell response to human chrionic gonadotropin. J Clin Endocrinol Metab 1980; 51: 35-41.

[104] Nieschlag E, Lammers U, Freischem CW, Langer K, Wickings EJ. Reproductive functions in young fathers and grandfathers. J Clin Endocrinol Metab 1982; 55: 676-81.

[105] Giusti G, Gonnelli P, Borrelli D, et al. Age-related secretion of androstenedione, testosterone and dihydrotestosterone by the human testis. Exp Gerentol 1975; 10: 241-5.

[106] Zumnoff B, Strain GW, Kream J, et al. Age variation of the 24hour mean plasma concentrations of androgens, estrogens, and gonadotropins in normal adult men. J Clin Endocrinol Metab 1982; 54: 534-8.

[107] Bremner WJ, Prinz PN. A loss of circadian rhythmicity in blood testosterone levels with aging in normal men. J Clin Endocrinol Metab 1983; 56: 1278-81.

[108] Tenover JS, Matsumoto AM, Plymate SR, Bremner WJ. The effects of aging in normal men on bioavailable testosterone and luteinizing secretion: response to clomiphene citrate. J Clin Endocrinol Metab 1987; 65: 1118-26.

[109] Gray A, Berlin JA, McKinlay JB, Longcope C. An examination of research design effects on the association of testosterone and male aging: results of meta-analysis. J Clin Epidemiol 1991; 44: 671-84.

[110] Gray A, Feldman HA, McKinlay JB, Longcope C. Age, disease, and changing sex hormone levels in middle-aged men: results of the Massachusetts Male Aging Study. J Clin Endocrinol Metab 1991; 73: 1016-25.

[111] Simon D, Preziosi P, Barrett-Connor, et al. The influence of aging on human sex hormones in men: the Telecom Study. Am J Epidemiol 1992; 135: 783-91.

[112] De Lignieres B. Transdermal dihydrotestosterone treatment of "andropausd." Ann Med 1993; 25: 235-41.

[113] Morley JE, Kaiser FE, Pery HM III, et al. Longitudinal changes in testosterone, luteinizing hormone, and follicle stimulating hormone in healthy older men. Metabolism 1997; 46: 410-3.

[114] Zmuda JM, Cauley JA, Kriska A, Glynn NW, Gutai J, Kuller LH. Longitudinal relation between endogenous testosterone and cardio- vascular disease risk factors in middle-aged men: a 13 year followup of former multiple risk factor intervention trial participants. Am J Epidemiol 1997; 146: 609-17.

[115] Ferrini RL, Barrett-Connor E. Sex hormone and age: a crosssectional study of testosterone and estradiol and their bioavailable fractions in community-dwelling men. Am J Epidemiol 1998; 147: 750-4.

[116] Harman SM, Metter EJ, Tobin JD, Pearson J, Blackman MR. Longitudinal effects of aging on serum total and free testosterone levels in healthy men. Baltimore longitudinal study of aging. J Clin Endocrinol Metab 2001; 86: 724-31.

[117] Feldman HA, Longcope C, Derby CA, et al. Age trends in the level of serum testosterone and other hormones in middle-aged men: longitudinal results from Massachusetts male aging study. J Clin Endocrinol Metab 2002; 87: 589-98.

[118] Schatzl G, Madersbacher S, Temml C, et al. Serum androgen levels: impact of health status and age. Urology 2002; 61: 629-33.

[119] Svartberg J, Midtbuy M, Bonaa KH, Sundsfjord J, Joakimsen RM, Jorde R. The association of age, lifestyle factors and chronic disease with testosterone in men: the Tromso Study. Eur J Endocrinol 2003; 149: 145-52.

[120] Allan CA, McLachlan RL. Age-related changes in testosterone and the role of replacement therapy in older men. Clin Endocrinol (Oxf) 2004; 60: 653-70.

[121] Araujo AB, O'Donnell AB, Brambilla DJ, et al. Prevalence and incidence of androgen deficiency in middle-aged and older men: estimates from the Massachusetts Male Aging Study. J Clin Endocrinol Metab 2004; 89: 5920-6.

[122] Liu PY, Swerdloff RS, Veldhuis JD. The rationale, efficacy and safety of androgen therapy in older men. J Clin Endocrinol Metab 2004; 89: 4789-96.

[123] Wu AH, Whittemore AS, Kolonel LN, et al. Serum androgens and sex hormone-binding globulins in relation to lifestyle factors in older African-American, white, and Asian men in the United States and Canada. Cancer Epidemiol Biomakers Prev 1995; 4: 735-41.

[124] Tenover JS. Declining testicular function in aging men. Int J Impot Res 2003; 15 (Suppl. 4): S3-8.

[125] Harman SM. Testosterone in older men after the Institute of Medicine Report: where do we go from here? Climacteric 2005; 8: 124 35 .

[126] Morley JE, Charlton E, Patrick P, et al. Validation of a screening questionnaire for androgen deficiency in aging males. Metabolism 2000; 49: 1239-42.

[127] Korenman SG, Morley JE, Mooradian AD, et al. Secondary hypogonadism in older men: an evidence based approach. J Clin Endocrinol Metab 1990; 71: 963-9.

[128] Liu PY, Swerdloff RS, Wang C. Relative testosterone deficiency in older men: Clinical definition and presentation. Endocrinol Metab Clin N Am 2005; 34: 957-72.

[129] Araujo AB, Esche GR, Kupelian V, et al. Prevalence of symptomatic androgen deficiency in men. J Clin Endocrinol Metab 2007; 92: 4241-7.

[130] Swerdloff RS, Heber D. Effects of aging on male reproductive function. In: Korenman SG, Ed. Endocrine aspects of aging. New York, NY: Elsevier Biomedical 1982; pp. 119-35.

[131] Liu PY, Iranmanesh A, Nehra AX, Keenan DM, Veldhuis JD. Mechanism of hypoandrogenemia in healthy aging men. Endocrinol Metab Clin N Am 2005; 34: 935-55.

[132] Haren MT, Kim MJ, Tariq SH, Wittert GA, Morley JE. Andropause: a quality-of-life issue in older males. Med Clin N Am 2006; 90: 1005-23.

[133] Harman SM, Talbert GB. Reproductive aging. In: Finch CE, Schneider EL, Eds. Handbook of the biology of aging. New York, NY: Van Norstrand Reinhold Co. 1985; pp. 457-510.

[134] Sarjent JW, McDonald JR. A method for the quantitative estimate of Leydig cells in human testis. Mayo Clin Proc 1948; 23: 249-54.

[135] Tillenger KG. Testicular morphology. Acta Endocrinol (Copenh.) (Suppl.) 1957; 24: 1-192.

[136] Frick J. Darstellung einer Methode zur bestimmung des Testosteronspiegls implasma und Studie uber den testosterone Metabolismus beim mahn uber 60 Jahre. Urol Int 1969; 24: 481-501.

[137] Harbitz TB. Testis weight and the histology of the prostate in elderly men. Analysis in an autopsy series. Acta Pathol Microbiol Scand 1973; 81A: 148-58. 
[138] Kaler LW, Neaves WB. Attrition of human Leydig cell population with advancing age. Anat Rec 1978; 192: 513-8.

[139] Sniffen RC. The testis. I. The normal testis. Arch Pathol 1950; 50: 259-84.

[140] Sokal Z. Morphology of the human testes in various periods of life. Folia Morphol 1964; 23:102-11.

[141] Kothari KL, Gupta AS. Effect of aging on the volume, structure, and total Leydig cell content of the human testis. Int J Fertil 1974; 19: 140-6.

[142] Nieschlag E, Kley KH, Wieglemann W. Age dependence of the endocrine testicular function in adult men. Acta Endocrinol (Copenh.) (Suppl.) 1973; 177: 22.

[143] Baker HWG, Burger HG, de Krestser DM, et al. Changes in the pituitary-testicular system with age. Clin Endocrinol (Oxf) 1976; 5: 349-72.

[144] Reubens R, Dhondt M, Vermeulen A. Further studies on Leydig cell response to human choriogonadotropin. J Clin Endocrinol Metab 1976; 39: 40-5.

[145] Longcope C. The effect of human chrionic gonadotropin on plasma steroid levels in young and old men. Steroids 1973; 21: 583-92.

[146] Nankin HR, Lin T, Murano EP. The aging Leydig cell. III. Gonadotropin stimulation in men. J Androl 1981; 2: 181-6.

[147] Veldhuis JD, Veldhuis NJD, Keenan DM, Iranmanesh A. Age diminishes the testicular steroidogenic response to repeated intravenous pulses of recombinant human $\mathrm{LH}$ during acute $\mathrm{GnRH}-$ receptor blockade in healthy men. Am J Physiol Endocrinol Metab (2005); 288: E775-81.

[148] Takahashi PY, Votruba P, Abu-Rub M, Mielke K, Veldhuis JD. Age attenuates testosterone secretion driven by amplitude-varying pulses of recombinant human luteinizing hormone during acute gonadotrope inhibition in healthy men. J Clin Endocrinol Metab 2007; 92: 3626-32.

[149] Sasano N, Sadatoshi I. Vascular patterns of the human testis with special reference to its senile changes. Tohuku J Exp Med 1969; 99: 269-76.

[150] Takizawa T, Hatakeyama S. Age-associated changes in microvasculature of human adult testis. Acta Pathol Jpn 1978; 28: 541-54.

[151] Honore LH. Aging changes in the human testis: a light microscopic study. Gerontology 1978; 24: 58-65.

[152] Neaves WB, Johnson L, Porter JC, Parker CR, Petty CS. Leydig cell numbers, daily sperm production, and serum gonadotropin levels in aging men. J Clin Endocrinol Metab 1984; 59: 756-63.

[153] Paniagua R, Amat P, Nistal M, Martin A. Ultrastructure of Leydig cells in human ageing testes. J Anat 1986; 146: 173-83.

[154] Liu PY, Pincus SM, Takahashi PY, et al. Aging attenuates both the regularity and joint synchrony of $\mathrm{LH}$ and testosterone secretion in normal men: analyses via a model of graded GnRH receptor blockade. Am J Physiol Endocrinol Metab 2004; 290: E34-41.

[155] Takahashi PY, Liu PY, Roebuck PD, Iranmanesh A, Veldhuis JD. Graded inhibition of pulsatile luteinizing hormone secretion by a selective gonadotropin-releasing hormone (GnRH)-receptor antagonist in healthy men: evpdence that age attenuates hypothalamic GnRH outflow. J Clin Endocrinol Metab 2005; 90: 2768-74.

[156] Keenan DM, Takahashi PY, Liu PY, et al. An ensemble model of the male gonadal axis: illustrative application in aging men. Endocrinology 2006; 147: 2817-28.

[157] Ghanadian R, Lewis JG, Chisholm GD. Serum testosterone and dihydrotestosterone changes with age in rat. Steroids 1975; 25 : 753-62.

[158] Chan SWC, Leathem JH, Esashi T. Testicular metabolism and serum testosterone in aging male rats. Endocrinology 1977; 101: 128-33.

[159] Gray GD. Changes in the levels of luteinizing hormone and testosterone in the circulation of aging male rats. J Endocrinol 1978; 76 (3): 551-2.

[160] Harman SM, Danner RL, Roth GS. Testosterone secretion in the rat in response to chorionic gonadotropin: alteration with age. Endocrinology 1978; 102: 540-4.

[161] Miller AE, Riegle GD. Serum testosterone and testicular response to hCG in young and aged male rats. J Gerontol 1978; 33: 197-203.

[162] Pirke KM, Vogt HJ, Geiss M. In vitro and in vivo studies on Leydig cell function in old rats. Acta Endocrinol (Copenh) 1978; 89: 393403 .
[163] Pirke KM, Bofilias I, Sintermann R, Langhammer H, Wolf I, Pabst HW. Relative capillary blood flow and Leydig cell function in old rats. Endocrinology 1979; 105: 842-5.

[164] Kinoshita Y, Higashi Y, Winters SJ, Oshima H, Troen P. An analysis of the age-related decline in testicular steroidogenesis in the rat. Biol Reprod 1985; 32: 309-14.

[165] Gruenewald DA, Hess DL, Wilkinson CW, Matsumoto AM. Excessive testicular progesterone secretion in aged male Fischer 344 rats: a potential cause of age-related gonadotropin suppression and confounding variable in aging studies. J Gerontol 1992; 47: B16470 .

[166] Wang C, Leung A, Sinha-Hikim AP. Reproductive aging in the male Brown-Norway rat: a model for the human. Endocrinology 1993; 133: 2773-81

[167] Gruenewald DA, Naai MA, Hess DL, Matsumoto AM. The Brown Norway rats as a model of male reproductive aging: evidence for both primary and secondary testicular failure. J Gerontol 1994; 49: B42-50.

[168] Mendis-Handagama SMLC, Gelber SJ. Signs of aging are apparent in the testis interstitium of Sprague-Dawley rats at 6 months of age. Tissue Cell 1995; 27: 689-99.

[169] Kim I, Ariyaratne S, Mendis-Handagama SMLC. Changes in the testis interstitium of Brown Norway rats with aging and effects of luteinizing and thyroid hormones on the aged testes in enhancing the steroidogenic potential. Biol Reprod 2002; 66:1359-66.

[170] Simpkins JW, Kalra PS, Kalra SP. Alterations in daily rhythms of testosterone and progesterone in old male rats. Exp Aging Res 1981; $7: 25-32$.

[171] Chan SWC, Leathem JH, Esashi T. Testicular metabolism and serum testosterone in aging male rats. Endocrinology 1977; 101: 128-13.

[172] Miller AE, Riegle GD. Serum testosterone and testicular response to hCG in young and aged male rats. J Gerontol 1978; 33: 197-203.

[173] Pirke KM, Krings B, Vogt HJ. Further studies on hypothalamicpituitary-testicular function in old rats. Acta Endocrinol 1979; 92: 358-69.

[174] Harman SM, Danner RL, Roth GS. Testosterone secretion in the rat in response to chorionic gonadotropin: alterations with age. Endocrinology 1978; 102: 540-4.

[175] Lin T, Murano E, Osterman J, Allen DO, Nankin HR. The aging Leydig cell: 1 . testosterone and adenosine 3':5'-monophosphate responses to gonadotropin in rats. Steroids 1980; 35: 653-63.

[176] Lehmann H, Lutzen L, Deutsch H. Hormonal activity of testis in aged rats with Leydig cell hyperplasia: histochemical investigation of some hydroxysteroid dehydrogenases. Beitrage zur Pathologie 1975; 156: 109-16.

[177] Kaler LW, Neaves WB. The androgen status of aging male rats. Endocrinology 1981; 108: 712-9.

[178] Ichihara I, Kawamura H, Palliniemi LJ. Ultrastructure and morphometry of testicular Leydig cells and the interstitial components correlated with testosterone in aging rats. Cell Tissue Res 1993; 271: 214-55.

[179] Johnson L, Neaves WB. Age related changes in the Leydig cell population, seminiferous tubules and sperm production in stallions. Biol Reprod 1981; 24: 703-12.

[180] Chen H, Hardy MP, Huhtaniemi I, Zirkin BR. Age-related decreased Leydig cell testosterone production in the Brown Norway rat. J Androl 1994; 15: 551-7.

[181] Bethea CL, Walker RF. Age-related changes in reproductive hormones and in Leydig cel responsivity in the male Fischer 344 rat. J Gerontol 1979; 34: 21-7.

[182] Tsitouras PD, Kowatch MA, Harman M. Age-related alterations of isolated rat Leydig cell function: gonadotropins receptors, adenosine 3',5'-monophosphate response and testosterone secretion. Endocrinology 1979; 105: 1400-5.

[183] Liao C, Reaven E, Azhar S. Age-related decline in the steroidogenic capacity of isolated Leydig cells: a defect in cholesterol mobilization and processing. J Steroid Biochem Mol Biol 1993; 46: 39-47.

[184] Tsitouras PD, Kowatch MA, Balckman MR, Hraman SM. In vivo chronic gonadotropin administration reverses secretory defect of Leydig cells from old rats. J Gerontol 1984; 39: 257-63.

[185] Steger RW, Peluso JJ, Bruni JF, Hafez ESE, Meites J. Gonadotropin binding and testicular function in old rats. Endokrinologie 1979; 73: 1-5. 
[186] Chen GCC, Lin T, Murono E, Osterman J, Cole BY, Nankin H. The aging Leydig cells: 2 . Two distinct populations of Leydig cells and the possible site of defective steroidogenesis. Steroids 1981; 37: 63-72.

[187] Chen H, Hardy MP, Zirkin BR. Age-related decreases in Leydig cell testosterone are not restored by exposure to LH in vitro. Endocrinology 2002; 142: 1637-42.

[188] Zirkin BR, Chen H, Luo L. Leydig cell steroidogenesis in aging rats. Exp Gerontol 1997; 32: 529-37.

[189] Lin T, Vinson NE, Murano EP, Osterman J, Nankin HR. The aging Leydig cell: VIII Protein kinase activity. J Androl 1983; 4: 324-30.

[190] Chen H, Liu J, Zirkin BR. Dibutyryl cyclic adenosine monophosphate restores the ability of aged Leydig cells to produce testosterone at the high levels characteristic of young cells. Endocrinology 2004; 145: 4441-6.

[191] Collins PM, Bell JB, Tsang WN. The effect of vasectomy on steroid metabolism by the seminiferous tubules and intestinal tissue of the rat testis-a comparison with the effects of aging. J Endocrinol 1972; 55: 108-10.

[192] Luo L, Chen H, Zirkin BR. Are Leydig cell steroidogenic enzymes differentially regulated with aging? J Androl 1996; 17: 509-15.

[193] Chan SWC, Leathem JH, Esashi T. Testicular metabolism and serum testosterone in aging male rats. Endocrinology 1977, 101: 128-33.

[194] Leers-Sucheta S, Stocco DM, Azhar S. Down-regulation of steroidogenic acute regulatory (StAR) protein in rat Leydig cells: implications for regulation of testosterone production during aging. Mech Ageing Dev 1999; 107: 197-203.

[195] Luo L, Chen H, Zirkin BR. Leydig cell aging: steroidogenic acute regulatory protein (StAR) and cholesterol side-chain cleavage enzyme. J Androl 2001; 22: 149-56.

[196] Culty M, Luo L, Yao Z-X, Chen H, Papadopoulos V, Zirkin BR. Cholesterol transport, peripheral benzodiazepine receptor and steroidogenesis in aging Leydig cells. J Androl 2002; 23: 439-47.

[197] Sun Z, Shen W-J, Sucheta S-L, Azhar S. Impact of aging on cholesterol transport protein expression and steroidogenesis in rat testicular Leydig cells. Open Longev Sci 2008; 2: 76-85.

[198] Eleftheriou BE, Lucas LA. Age-related changes in testes, seminal vesicles and plasma testosterone levels in male mice. Gerentologica 1974; 20: 231-9.

[199] Nelson JF, Lathnum KR, Finch CE. Plasma testosterone levels in C57BL/6J male mice: effects of age and disease. Acta Endocrinol (Copenh). 1975; 80: 744-52.

[200] Bronson FH, Desjardins C. Reproductive failure in aged CBF1 male mice: Interrelationships between pituitary gonadotropic hormones, testicular function, and mating success. Endocrinology 1977; 101: 939-45.

[201] Coquelin A, Desjardins C. Luteinizing hormone and testosterone secretion in young and old male mice. Am J Physiol 1982; 243: E257-63.

[202] Chandrashekar V, Dason CR, Martin ER, Rocha JS, Bartke A, Kopchick JJ. Age-related alteration in pituitary and testicular functions in long-lived growth hormone receptor gene-disrupted mice. Endocrinology 2007; 148: 6019-25.

[203] Huang HH, Meites J. Reproductive capacity of aging female rats. Neuroendocrinology 1975; 17: 289-95.

[204] Chan SW, Leathem JH. Aging and ovarian steroidogenesis in the rat. J Gerontol 1977; 32: 395-401.

[205] Peluso JJ, Montgomery MK, Steger RW, Meites J, Sacher G. Aging and ovarian function in the white-footed mouse (Peromyscus leucopus) with specific reference to the development of preovulatory follicles. Exp Aging Res 1980; 6: 317-28.

[206] Albrecht ED. Pregnancy in young and aged rats: I. Ovarian progesterone and 20 alpha-hydroxypregn-4-en-3-one formation. Endocrinology 1984; 115: 1418-25.

[207] Albrecht ED. Pregnancy in young and aged rats: II. Peripheral serum progesterone concentrations. Biol Reprod 1985; 33: 432-55.

[208] Steger RW, Peluso JJ. Sex hormones in the aging frmale. Endocrinol Metab Clin North Am 1987; 16: 1027-43.

[209] Goya RG, Lu JK, Meites J. Gonadal function in aging rats and its relation to pituitary and mammary pathology. Mech Ageing Dev 1990; 56: 77-88.

[210] Brann DW, Mahesh VB. The aging reproductive neuroendocrine axis. Steroids 2005; 70: 273-83.
[211] Wu JM, Zelinski MB, Ingram DK, Ottinger MA. Ovarian ageing and menopause: current theories, hypotheses, and research models. Exp Biol Med 2005; 230: 818-28.

[212] Hall JE, Gill S. Neuroendocrine aspects of aging in women. Endocrinol Metab Clin North Am 2001; 30: 631-46.

[213] Burger HG, Dudley E, Mamers P, Robertson D, Groome N, Dennerstein L. The ageing female reproductive axis I. Novartis Found Symp 2002; 242: 161-7.

[214] Wise PM, Smith MJ, Dubal DB, et al. Neuroendocrine modulation and repercussions of female reproductive aging. Recent Prog Horm Res 2002; 57: 235-56.

[215] Hall JE. Neuroendocrine physiology of the early and late menopause. Endocrinol Metab Clin N Am 2004; 33: 637-59.

[216] Hall JE. Neuroendocrine changes with reproductive aging in women. Semin Reprod Med 2007; 25: 344-51.

[217] Gosden RG, Faddy MJ. Ovarian aging, follicular depletion and steroidogenesis. Exp Gerontol 1994; 29: 265-74.

[218] Burger HG, Dudley EC, Robertson DM, Dennerstein L. Hormonal changes in the menopause transition. Recent Prog Horm Res 2002; 57: 257-75.

[219] Hale GE, Burger HG. Perimenopausal reproductive endocrinology. Endocrinol Metab Clin North Am 2005; 34: 907-22.

[220] Santoro N. The menopausal transition. Am J Med 2005; 118(Suppl. 12B): $8-13$.

[221] Burger HG, Hale GE, Dennerstein L, Robertson DM. Cycle and hormone changes during perimenopause: the key role of ovarian function. Menopause 2008; 15: 603-12.

[222] Adashi EY. Endocrinology of the ovary. Hum Reprod 1994; 9: 815-27.

[223] Gore-Langton RE, Armstrong DT. Follicular steroidogenesis and its control. In: Knobil E, Neill J, Eds. The Physiology of reproduction. $2^{\text {nd }}$ ed. New York, NY: Raven Press 1994; Vol. 1, pp. 571628.

[224] Conley A, Hinshelwood M. Mammalian aromatases. Reproduction 2001; 121: 685-95.

[225] Suzuki T, Sasano H, Tamura M, et al. Temporal and spatial localization of steroidogenic enzymes in premenopausal human ovaries: in situ hybridization and immunohistochemical study. Mol Cell Endocrinol 1993; 97:135-43.

[226] Yen SSC. The human menstrual cycle (Integrative function of the hypothalamic-pituitary-ovarian-endometrial axis). In: Yen SSC, Jaffe RB, Eds. Reproductive Endocrinology: Physiology, pathophysiology and clinical management. Philadelphia, PA: W.B. Saunders Company 2004; pp. 126-51.

[227] Farage MA, Neill S, MacLean AB. Physiological changes associated with the menstrual cycle: a review. Obstet Gynecol Surv 2009; 64: 58-72.

[228] Johnson SR. Menopause and hormone replacement therapy. Med Clin North Am 1998; 82: 297-320.

[229] Perry HM III. The endocrinology of aging. Clin Chem 1999; 45: 1369-76.

[230] Hall JE. Neuroendocrine physiology of the early and late menopause. Endocrinol Metab Clin N Am 2004; 33: 637-59.

[231] Hale GE, Burger HG. Hormonal changes and biomarkers in late reproductive age, menopausal transition and menopause. Best Pract Res Clin Obstet Gynecol 2009; 23: 7-23.

[232] Sherman BM, Korenman SG. Hormonal characteristics of the human menstrual cycle throughout reproductive life. J Clin Invest 1975; 55: 699-706.

[233] Korenman SG, Sherman BM, Korenman JC. Reproductive hormone function: the perimenopausal period and beyond. Clin Endocrinol Metab 1978; 7: 625-43.

[234] MacNaughton J, Banah M, McCloud P, Hee J, Burger H. Age related changes in follicle stimulating hormone, luteinizing hormone, oestradiol and immunoreactive inhibin in women reproductive age. Clin Endocrinol (Oxf) 1992; 36: 339-45.

[235] Burger HG, Dudley EC, Hopper JL, et al. Prospectively measured levels of serum follicle-stimulating hormone, estradiol, and the dimeric inhibins during the menopausal transition in a populationbased cohort of women. J Clin Endocrinol Metab 1999; 84: 402530.

[236] Burger HG, Cahir N, Robertson DM, et al. Serum inhibins A and B fall differently as FSH rises in perimenopausal women. Clin Endocrinol (Oxf) 1998; 48: 809-13. 
[237] Burger HG, Dudley E, Mamers P, Groome N, Robertson DM. Early follicular phase serum FSH as a function of age: the roles of inhibin B, inhibin A and estradiol. Climacteric 2000; 3: 17-24.

[238] Davison SL, Bell R, Donath S, Montalto JG, Davis SR. Androgen levels in adult females: changes with age, menopause, and oophorectomy. J Clin Endocrinol Metab 2005; 90: 3847-53.

[239] Overlie I, Moen MH, Morkrid L, Skjaeraasen JS, Holte A. The endocrine transition around menopause-a five years prospective study with profiles of gonadotropines, estrogens, androgens and SHBG among healthy women. Acta Obstet Gynecol Scand 1999; 78: 642-7.

[240] Randolph JF, Jr, Sowers M, Bondarenko IV, et al. Changes in estradiol and follicle-stimulating hormone across the early menopausal transition: effects of ethnicity and age. J Clin Endocrinol Metab 2004; 89:1555-61.

[241] Adashi EY. The climacteric ovary as a functional gonadotropindriven androgen-producing gland. Fertil Steril 1994; 62: 20-7.

[242] Shifren JL, Schiff I.The aging ovary. J Womens Health Gen Based Med 2000; 9:S3-7

[243] Judd H, Lucas W, Yen S. Effects of oophorectomy on circulating testosterone and androstenedione levels in patients with endometrial cancer. Am J Obstet Gynecol 1974; 118: 793-8.

[244] Rannevik G, Jeppsson S, Johnell O, Bjerre B, Laurel-Borulf Y, Svanberg L. A longitudinal study of the perimenopausal transition: altered profiles of steroids and the pituitary hormones, SHBG and bone mineral density. Maturitas 1995; 21: 103-13.

[245] Meldrum DR, Davidson BJ, Tataryn IV, Judd HL. Changes in circulating steroids with aging in postmenopausal women. Obstet Gynecol 1981; 57: 624-8.

[246] McKinlay SM, Brambilla DJ, Posner JG. The normal menopause transition. Maturitas 1992; 14:103-15.

[247] Speroff L. Menopause and hormone replacement therapy. Clin Geriatr Med 1993; 9: 33-56

[248] Romanoff LP, Morris CW, Welch P, Rodriguez RM, Pincus G. The metabolism of cortisol-4-C $\mathrm{C}^{14}$ in young and elderly men. I. Secretion rate of cortisol and daily excretion of tetrahydrocortisol, allotetrahydrocortisol, tetrahydrocortisone and cortolone (20 $\alpha$ and $20 \beta)$. J Clin Endocrinol Metab 1961;21: 1413-25.

[249] West CD, Brown H, Simons EL, Carter DB, Kumagai LF, Englert E Jr. Adrenocortical function and cortisol metabolism in old age. J Clin Endocrinol 1961; 10: 1197-207.

[250] Grad B, Kral VA, Payne RC, Berenson J. Plasma and urinary corticoids in young and old persons. J Gerentol 1967; 22: 66-71

[251] Friedman M, Green MF, Sharland DE. Assessment of hypothalamic-pituitary-adrenal function in a geriatric age group. J Gerontol 1969; 24: 292-7.

[252] Blichert-Toft M, Blichert-Toft B, Jensen HK. Pituitaryadrenocortical stimulation in the aged as reflected in levels of plasma cortisol and Compound S. Acta Chir Scand 1970; 136: 66570.

[253] Blichert-Toft M. Assessment of serum corticotrophin concentration and its nyctohemeral rhythm in the aging. Gerontol Clin 1971; 13: 215-20.

[254] Jensen HK, Blichert-Toft M. Serum corticotrophin, plasma cortisol and urinary excretion of 17-ketogenic steroids in the elderly (age group: 66-94 years). Acta Endocrinol (Copenh) 1971; 66: 25-34.

[255] Blichert-Toft M. Secretion of corticotrophin and somatotrophin by the senescent adenohypophysis in man. Acta Endocrinol (Copenh) [Suppl] 1975; 195: 11-55.

[256] Kley HK, Nieschlag E, Kruskemper HI. Age dependence of plasma oestrogen response to HCG and ACTH in men. Acta Endocrinol (Copenh) 1975; 79: 95-101.

[257] Dean S, Felton SP. Circadian rhythm in the elderly: a study using cortisol-specific radio-immunoassay. Age Ageing 1979; 8: 243-5.

[258] Tourigny-Rivard MF, Raskind M, Rivard D. The dexamethasone suppression test in the elderly population. Biol Psychiatry 1981; 16: 1177-84.

[259] Vermeulin A, Deslypere JP, Schelfhout W, Verdonck L, Rubens R. Adrecortical function in old age: response to acute adrenocorticotropin stimulation. J Clin Endocrinol Metab 1982; 54: 187-91.

[260] Pavlov EP, Harman SM, Chrousos GP, Loriaux DL, Blackman MR. Responses of plasma adrenocorticotropin, cortisol, and dehydroepiandrosterone to ovine corticotrophin-releasing hormone in healthy aging. J Clin Endocrinol Metab 1986; 62: 767-72.
[261] Waltman C, Blackman MR, Chrousos GP, Riemann C, Harman SM. Spontaneous and glucocorticoid-inhibited adrenocorticotropic hormone and cortisol secretion are similar in healthy young and old men. J Clin Endocrinol Metab 1991; 73: 495-502.

[262] Seeman TE, Robbins RJ. Aging and hypothalamic-pituitary-adrenal response to challenge in humans. Endocr Rev 1994; 15: 233-60.

[263] Svec F. Ageing and adrenal cortical function. Baillieres Clin Endocrinol Metab 1997; 11: 271-87

[264] Huizenga MATM, Koper JW, De Lange P, et al. Interperson variability but interperson stability of baseline plasma cortisol concentrations, and its relation to feedback sensitivity of the hypothalamopituitary-adrenal axis to a low dose of dexamethasone in elderly individuals. J Clin Endocrnol Metab 1998; 83: 47-54.

[265] Rubin RT, Rhodes ME, O’Toole S, Czambel RK. Sexual diergism of hypothalamo-pituitary-adrenal cortical responses to low-dose physotigamine in elderly vs young women and men. Neuropsychopharmacology 2002; 26: 672-81.

[266] Kudielka BM, Buske-Kirschbaum A, Hellhammer DH, Kirschbaum C. HPA axis responses to laboratory psychosocial stress in healthy elderly adults, younger adults, and children: impact of age and gender. Psychoneuroendocrinology 2004; 29: 83-98.

[267] Romanoff LP, Baxter MN. The secretion rates of deoxycorticosterone in young and elderly men. J Clin Endocrinol Metab 1975; 41: 630-3.

[268] Drafta D, Schindler AE, Store E, Meascu E. Age-related changes of plasma steroids in normal adult males. J Steroid Biochem 1982; 17: 683-7.

[269] van Cauter E, Leproult RDK, Kupfer DJ. Effects of gender and age on the levels and circadian rhythmicity of plasma cortisol. J Clin Endocrinol Metab 1996; 81: 2468-73.

[270] Deuschle M, Gotthardt U, Schweiger U, et al. With aging in humans the activity of the hypothalamus-pituitary-adrenal system increases and its diurnal amplitude flattens. Life Sci 1997; 61: 223946

[271] Wilkinson CW, Peskind ER, Raskind MA. Decreased hypothalamic-pituitary-adrenal axis sensitivity to cortisol feedback inhibition in human aging. Neuroendocrinology 1997; 65: 79-90.

[272] Yen SSC, Laughlin GA. Aging and the adrenal cortex. Exp Gerontol 1998; 33:897-910.

[273] Seeman TE, Singer B, Wilkinson CW, McEwen B. Gender differences in age-related changes in HPA axis reactivity. Psychoneuroendocrinology $2001 ; 26: 225-40$

[274] Silverberg A, Rizzo F, Krieger DT. Nyctohemeral periodicity of plasma 17-OHCS levels in elderly subjects. J Clin Endocrinol Metab 1968; 28: 1661-3.

[275] Grad B, Rosenberg GM, Liberman H. Diurnal variation of serum cortisol levels of geriatric subjects. J Gerentol 1971; 26: 351-7.

[276] Krieger DT, Allen W, Rizzo AW, Krieger HP. Characterization of the normal temporal pattern of plasma corticosteroid levels. J Clin Endocrinol 1971; 32: 266-84.

[277] Colucci CF, D’Alessandro B, Bellastella A, Montalbetti N. Circadian rhythm of plasma cortisol in the aged (cosinor method) Gerontol Clin 1975; 17: 89-95.

[278] Touitou Y. Some aspects of the circadian time structure in the elderly. Gerontology 1982; 28 (Suppl. 1): 53-67.

[279] Touitou Y, Sulon J, Bogdan A, Reinberg A, Sodoyez JC,DemeyPonsart E. Adrenocortical hormones, ageing and mental condition: seasonal and circadian rhythms of plasma 18-hydroxy-11deoxycorticosterone, total and free cortisol and urinary corticosteroids. J Endocrinol 1983; 96: 53-64.

[280] Rolandi E, Franceschini R, Marabini A, et al. Twenty -four-hour beta-endorphin secretory pattern in the elderly. Acta Endocrinol (Copenh) 1987; 115: 441-6.

[281] Green MF, Friedman M. Hypothalamic-pituitary-adrenal function in the elderly. Gerontol Clin 1968; 10: 334-9.

[282] Sharma M, Palacios-Boris J, Schwartz G, et al. Circadian rhythms of melatonin and cortisol in aging.Biol. Psychiatry 1989; 25: $305-$ 19.

[283] Sherman B, Wysham C, Pfohl B. Age-related changes in the circadian rhythm of plasma cortisol in man. J Clin Endocrinol Metab 1985; 61: 439-43.

[284] Keen DM, Roelfsema F, Carroll BJ, Iranmanesh A, Veldhuis JD. Sex defines the age dependence of endogenous ACTH-cortisol dose responsiveness. Am J Physiol Regul Integr Comp Physiol 2009; 297: R515-23. 
[285] Serio M, Piolanti P, Romano S, De Magistris L, Guisti G. The circadium rhythm of plasma cortisol in man. J Clin Endocrinol Metab 1970; 61: 439-43

[286] Kern W, Dodt C, Born J, Fehm HL. Changes in cortisol and growth hormone secretion during nocturnal sleep in the course of aging. $\mathrm{J}$ Gerontol A Biol Sci Med Sci 1996; 51: M3-9.

[287] Magri F, Locatelli M, Balza G, et al. Changes in endocrine circadian rhythms as markers of physiological and pathological brain aging. Chronobiol Int 1997; 14: 385-96.

[288] Heuser IJ, Gothardt U, Schweiger U, et al. Age-associated changes of pituitary-adrenocortical hormone regulation in humans: importance of gender. Neurobiol Aging 1994; 15: 227-31.

[289] Born J, Ditschuneit I, Schreiber M, Dodt C, Fehm HL. Effects of age and gender on pituitary-adrenocortical responsiveness in humans. Eur J Endocrinol 1995; 132: 705-11.

[290] Gotthardt U, Schweiger U, Fahrenberg J, et al. Cortisol, ACTH, and cardiovascular response to a cognitive challenge paradigm in aging and depression. Am J Physiol Regul Integr Comp Physiol 1995; 268: R865-73.

[291] Luisi S, Tonetti A, Bernardi F, et al. Effect of acute corticotrophin releasing factor on pituitary-adrenocortical responsiveness in elderly women and men. J Endocrinol Invest 1998; 21: 449-53.

[292] Kudielka BM, Buske-Kirschbaum A, Hellhammer DH, Kirschbaum C. HPA axis responses to laboratory psychococial stress in healthy elderly adults, younger adults, and chikdren: impact of age and gender. Psychoneuroendocrinology 2004; 29: 83-98.

[293] Raskind MA, Peskind ER, Pascualy M, et al. The effects of normal aging on cortisol and adrenocorticotropin responses to hypertonic saline infusion. Psychoneuroendocrinology 1995; 20: 637-44.

[294] Peskind ER, Raskind MA, Winggerson D, et al. Enhanced hypothalamic-pituitary-adrenocortical axis responses to physostigmine in normal aging. J Gerontol A: Biol Sci Med Sci 1995; 50z: M1520.

[295] Pritchett JF, Sartin JL, Marple DN, Harper WL, Till ML. Interaction of aging with in vitro adrenocortical responsiveness to ACTH and cyclic AMP. Horm Res 1079; 10: 96-103.

[296] Malamed S, Carsia RV. Aging of the rat adrenocortical cell: response to ACTH and cyclic AMP in vitro. J Gerontol 1983; 38: $130-6$.

[297] Popplewell PY, Tsubokawa M, Ramachandran J, Azhar S. Differential effects of aging on adrenocorticotropin receptors, adenosine 3'5'-monophosphate response, and corticosterone secretion in adrenocortical cells from Sprague-Dawley rats. Endocrinology 1986; 119: 2206-13.

[298] Popplewell PY, Azhar S. Effect of aging on cholesterol content and cholesterol-metabolizing enzymes in the rat adrenal gland. Endocrinology 1987; 121: 64-73.

[299] Reaven E, Kostrna M, Ramachandran J, Azhar S. Structure and functional changes in rat adrenal glands during aging. Am J Physiol 1988; 255: E903-11.

[300] Cheng B, Horst IA, Mader SL, Kowal J. Diminished adrenal steroidogenic activity in aging rats: new evidence from adrenal cells cutured from young and aged normal and hypoxic animals. Mol Cell Endocrinol 1990; 73: R7-12.

[301] Rebuffat P, Belloni AS, Rocco S, et al. The effects of ageing on the morphology and function of the zonae fasiculata and reticularis of the rat adrenal cortex. Cell Tissue Res 1992; 270: 265-72.

[302] Lo MJ, Kau KK, Cho WL, Wang PS. Aging effects on the secretion of corticosterone in male rats. J Investig Med 2000; 48: 33542.

[303] Popplewell PY, Butte J, Azhar S. The influence of age on steroidogenic enzyme activities of the rat adrenal gland: enhanced expression of cholesterol side-chain cleavage activity. Endocrinology 1987; 120: 252-28.

[304] Azhar S, Reaven E. Effect of age on cholesterol uptake and utilization by rat adrenals: I. Internalization of lipoprotein-derived cholesteryl esters. Mech Ageing Dev 1994; 77: 13-25.

[305] Reaven E, Cao L, Azhar S. Effect of age on cholesterol uptake and utilization by rat adrenals: II. Lipoproteins from young and old rats. Mech Ageing Dev 1994; 77: 27-41.

[306] Lo MJ, Kau MM, Chen JJ, et al. Age-related differences in corticosterone secretion in female rats. Metabolism 1999; 48: 535-641.

[307] Lo MJ, Chang LL, Wang PS. Effects of estradiol on corticosterone secretion in ovariectomized rats. J Cell Biochem 2000; 77: 560-8.
[308] Chang LL, Kau MM, Wun WS, Ho LT, Wang PS. Effect of fasting on corticosterone production by zona fasciculate-reticularis cells in ovariectomized rats. J Investig Med 2002; 50: 86-94.

[309] Lo MJ, Wang PS. Involvement of cAMP but not PKA in the increase of corticosterone secretion in rat zona fasiculata-reticularis cells by aging. J Cell Biochem 2002; 85: 35-41.

[310] Lo MJ, Kau MM, Wang PS. Effect of aging on corticosterone secretion in diestrous rats. J Cell Biochem 2006; 97: 351-5.

[311] Belloni AS, Rebuffat P, Malendowicz LK, Mazzocchi G, Rocco S, Nussdorfer GG. Age-related changes in the morphology and function of the zona glomerulosa of the rat adrenal cortex. Tissue Cell 1992; 24: 835-42.

[312] Radke KJ. Age-related impairment of $\mathrm{K}(+)$ - and ACTH-stimulated aldosterone secretion by rat adrenal capsules. Am J Physiol 1993; 264: E82-9.

[313] Adams JB. Control of secretion and the function of $\mathrm{C}_{19}-\Delta^{5}$-steroids of the human adrenal gland. Mol Cell Endocrinol 1985; 41: 1-17.

[314] Baulieu E-E. Dehydroepiandrosterone (DHEA): A fountain of youth? J Clin Endocrinol Metab 1996; 81:3147-51.

[315] Dharia S, Parker Jr CR. Adrenal androgens and aging. Semin Reprod Med 2004; 22: 361-8.

[316] Labrie F. Adrenal androgens and intracrinology. Semin Reprod Med 2004; 22: 299-309.

[317] Labrie F. Intracrinology. Mol Cell Endocrinol 1991; 78: C113-8.

[318] Vermeulen A. Dehydroepiandrosterone sulfate and aging. Ann NY Acad Sci 1995; 774: 121-7.

[319] Conley AJ, Pattison JC, Bird IM. Variations in adrenal androgen production among (nonhuman) primates. Semin Reprod Med 2004; 22: 311-26.

[320] Campbell B. Adrenarche and the evolution of human life history. Am J Hum Biol 2006; 18: 569-89.

[321] Nguyen AD, Conley AJ. Adrenal androgens in humans and nonhuman primates: Production, zonation and regulation. Endocr Dev 2008; 13:33-54.

[322] Abbott DH, Bird IM. Nonhuman primates as models for adrenal and androgen production: function and dysfunction. Rev Endocr Metab Disord 2009; 10: 33-42.

[323] Hinson JP, Raven PW. DHEA deficiency syndrome: a new term for old age? J Endocrinol 1999; 163: 1-5.

[324] Rainey WE, Carrr BR, Sasano H, Suzuki T, Mason JI. Dissecting human adrenal androgen production.Trends Endocrinol Metab 2002; 13: 234-9.

[325] Hornsby PJ. Aging of the human adrenal cortex. Sci Aging Knowledge Environ 2004; (35): re6.

[326] Abbott DH, Bird IM. Nonhuman primates as models human adrenal androgen production: function and dysfunction. Rev Endocr Metab Disord 2009; 10: 33-42.

[327] Arlt J, Martens JWM, Song M, Wang JT, Auchus RJ, Miller WL. Molecular evaluation of adrenarche: structural and functional analysis of P450c17 from four primate species. Endocrinology 2002; 143: 4665-72.

[328] Arlt W, Hewison M. Hormones and immune function: implications of aging. Aging Cell 2004; 3: 209-16.

[329] Cutler GB, Glenn M, Bush M, Hodgen GD, Graham CE, Loriaux L. Adrenarche: a survey of rodents, domestic animals, and primates. Endocrinology 1978; 103: 2112-8.

[330] Weinert BT, Timiras PS. Theories of aging. J Appl Physiol 2003; 95: 1706-16.

[331] Beckman KB, Ames BN. The free radical theory of aging matures. Physiol Rev 1998; 78: 547-81.

[332] Wickens AP. Aging and the free radical theory. Respir Physiol 2001; 128: 379-91.

[333] Harman D. The free radical theory of aging. Antioxid Redox Signal 2003; 5: 557-61.

[334] Harman D. Aging: the theory based on free radical and radiation chemistry. J Gerontol 1956; 11: 298-300.

[335] Judge S, Leeuwenburgh C. Cardiac mitochondrial bioenergetics, oxidative stress, and aging. Am J Physiol Cell Physiol 2007; 292: C1983-92.

[336] Bokov A, Chaudhuri A, Richardson A. The role of oxidative damage and stress in aging. Mech Ageing Devel 2004; 125: 811-26.

[337] Jang YC, van Remmen $\mathrm{H}$. The mitochondrial theory of aging: Insight from transgenic and knockout mouse models. Exp Gerentol 2009; 44: 256-60. 
[338] Harman D. The biologic clock: the mitochondria? J Am Geriatr Soc 1972; 20: 145-7.

[339] Miquel J, Economos AC, Fleming J, Johnson JE, Jr. Mitochondrial role in cell aging. Exp Gerontol 1980; 15: 575-91.

[340] Lenaz G, Bovina C, D'Aurelio M, et al. Role of mitochondria in oxidative stress and aging. Ann NY Acad Sci 2002; 959: 199-213.

[341] Sohal RS, Weindruch R. Oxidative stress, caloric restriction, aging. Science: 1996; 273: 59-63.

[342] Van Remmen H, Richardson A. Oxidative damage to mitochondria and aging. Exp Gerontol 2001; 36: 957-68.

[343] Harper JM, Salmon AB, Chang Y, Bonkowski M, Bartke A, Miller RA. Stress resistance and aging: influence of genes and nutrition. Mech Ageing Dev 2006; 127: 687-94.

[344] Muller FL, Lustgarten MS, Jang Y, Richardson A, van Remmen H. Trends in oxidative aging theories. Free Radic Biol Med 2007; 43: 477-503.

[345] Pérez VI, Bokoy A, van Remmen H, et al. Is the oxidative stress theory of aging dead? Biochim Biophys Acta 2009; 1790: 1005-14.

[346] Salmon AB, Richardson A, Pérez VI. Update on the oxidative stress theory of aging: Does oxidative stress play a role in aging or healthy aging? Free Radic Biol Med 2010; 48: 642-55.

[347] Durieux J, Wolff S, Dillin A. The cell-non-autonomous nature of electron transport chain-mediated longevity. Cell 2011; 144: 79-91.

[348] Woo DK, Shadel GS. Mitochondrial stress signals revised an old aging theory. Cell 2011; 144: 11-2.

[349] Brewer GJ. Epigenetic oxidative redox shift (EORS) theory of aging unifies the free radical and insulin signaling theories. Exp Gerontol 2010; $45: 173-9$

[350] Diplock AT, Charleux J-L, Crozier-Willi G, et al. Functional food science and defence against reactive oxidative species. Brit J Nutr 1998; 80 (Suppl 1): S77-112.

[351] Hulbert AJ, Pamplona R, Buffenstein R, Buttemer WA. Life and death: Metabolic rate, membrane composition, and life span of animals. Physiol Rev 2007; 87: 1175-213.

[352] Kregel KC, Zhang HL. An integrated view of oxidative stress in aging: basic mechanisms, functional effects, and pathological considerations. Am J Physiol Regul Integr Comp Physiol 2007; 292: R18-36.

[353] Jackson MJ, Papa S, Bolaños J, et al. Antioxidants, reactive oxygen and nitrogen species, gene induction and mitochondrial function. Mol Aspects Med 2002; 23: 209-85.

[354] Hulbert AJ, Pamplona R, Buffenstein R, Buttemer WA. Life and Death: Metabolic rate, membrane composition, and life span of animals. Physiol Rev 2007; 87: 1175-213.

[355] Wallace DC. A mitochondrial paradigm of metabolic and degenerative diseases, aging, and cancer: a dawn for evolutionary medicine. Annu Rev Genet 2005; 39: 359-407.

[356] Hanukoglu I. Antioxidant protective mechanisms against reactive oxygen species (ROS) generated by mitochondrial P450 systems in steroidogenic cells. Drug Metab Rev 2006; 38: 171-96.

[357] Nebert D, Dalton TP. The role of cytochrome P450 enzymes in endogenous signaling pathways and environmental carcinogenesis. Nat Rev Cancer 2006; 6: 947-60.

[358] Finkel T, Holbrook NJ. Oxidants, oxidative stress and the biology of ageing. Nature 408: 239-47.

[359] Orrenius S, Gogvadze V, Zhivotovsky B. Mitochondrial oxidative stress: implications for cell death. Annu Rev Pharmacol Toxicol 2007; 47: 143-83.

[360] Stowe DF, Camara AKS. Mitochondrial reactive oxygen species production in excitable cells: Modulators of mitochondrial and cell function. Antioxid Redox Signal 2008; 11: 1373-414.

[361] Hornsby PJ. Steroid and xenobiotic effects on the adrenal cortex: mediation by oxidative and other mechanisms. Free Radic Biol Med 1989; 6: 103-15.

[362] Rikans Rikans LE, Hornbrook KR. Lipid peroxidation, and antioxidant protection and aging. Biochim Biophys Acta 1997; 1362: 116-27.

[363] Spiteller G. Lipid peroxidation in aging and age-dependent diseases. Exp Gerontol 2001; 36 :1425-57.

[364] Praticò D. Lipid peroxidation and the aging process. Sci Aging Knowledge Environ 2002; 2002(50): re5.

[365] Pamplona R. Membrane phospholipids, lipoxidative damage and molecular integrity: a causal role in aging and longevity. Biochim Biophys Acta 2008; 1777:1249-62.
[366] Valko M, Leibfritz D, Moncol J, Cronin MTD, Mazur M, Telser J. Free radicals and antioxidants in normal physiological functions and human disease. Int J Biochem Cell Biol 2007; 39: 44-84.

[367] Horton JD, Goldstein JL, Brown MS. SREBPs: activators of the complete program of cholesterol and fatty acid synthesis in the liver. J Clin Invest 2002; 109: 1125-31.

[368] Goldstein JL, Brown MS. The LDL receptor. Arterioscler Thromb Vasc Biol 2009; 29: 431-8

[369] Miller WL, Auchus RJ. The molecular biology, biochemistry, and physiology of human steroidogenesis and its disorders. Endocr Rev 2011; 32: 81-151.

[370] Hornsby PJ, Crivello JF. The role of lipid peroxifation and biological antioxidants in the function of the adrenal cortex. Part 2. Mol Cell Endocrinol 1983; 30: 123-47.

[371] Aten RF, Duarte KM, Herman HR. Regulation of ovarian antioxidant vitamins, reduced glutathione, and lipid peroxidation by luteinizing hormone and prostaglandin $\mathrm{F}_{2 \alpha}$. Biol Reprod 1992; 46: 401-7.

[372] Azhar S, Cao L, Reaven E. Alteration of the adrenal antioxidant defense system during aging in rats. J Clin Invest 1995; 96: 1414 24

[373] Sugino N, Tokiguchi S, Kashida S, Karube A, Nakamura Y, Kato H. Superoxide dismutase expression in the human corpus luteum during the menstrual cycle and in early pregnancy. Mol Human Reprod 2000; 6: 19-25.

[374] Cao L, Leers-Sucheta S, Azhar S. Aging alters the functional expression of enzymatic and non-enzymatic anti-oxidant defense systems in testicular rat Leydig cells. J Steroid Biochem Mol Biol 2004; 88: 61-7.

[375] Luo L, Chen H, Trush MA, Show MD, Anway MD, Zirkin BR. Aging and the Brown Norway rat Leydig cell antioxidant defense system. J Androl 2006; 27: 240-7.

[376] Fridovich I. Superoxide radical and superoxide dismutase. Annu Rev Biochem 1995; 64: 97-112.

[377] Comhair SAA, Erzurum SC. Antioxidant responses to oxidantmediated lung diseases. Am J Physiol Lung Cell Mol Physiol 2002; 283: 1246-55.

[378] Mehlborn RJ. Oxidants and antioxidants in aging. In: Timiras PS, Ed. Physiological basis of aging and geriatrics. $3^{\text {rd }}$ ed. Boca Raton: CRC Press 2003; pp. 61-83.

[379] Brigelius-Flohé R. Glutathione peroxidases and redox-regulated transcription factors. Biol Chem 2006; 387: 1329-35.

[380] Kirkman HN, Gaetani GF. Mammalian catalase: a venerable enzyme with new mysteries. Trends Biochem Sci 2007; 32: 44-50.

[381] Kalinina EV, Chernov NN, Saprin AN. Involvement of thio-, peroxi-, and glutaredoxin in cellular redox-dependent processes. Biochemistry (Moscow) 2008; 73: 1493-510.

[382] Allen RG, Tresini M. Oxidative stress and gene regulation. Free Radic Biol Med 2000; 28: 463-99.

[383] Lum H, Roebuck KA. Oxidant stress and endothelial cell dysfunction. Am J Physiol Cell Physiol 2001; 280: C719-41.

[384] Dröge W. Free radicals in the physiological control of cell function Physiol Rev 2002; 82: 47-95.

[385] Klaunig JE, Kamenddulits LM. The role of oxidative stress in carcinogenesis. Annu Rev Pharmacol Toxicol 2004; 44: 239-67.

[386] Kensler TW, Wakabayashi N, Biswal S. Cell survival responses to environmental stresses via the Keapi-Nrf2-ARE pathway. Annu Rev Pharmacol Toxicol 2007; 47: 89-116.

[387] Medicherla R, Leers-Sucheta S, Lua Y, Azhar S. Impaired activation of AP-1 and altered expression of constituent proteins in rat adrenal during ageing. Mech Ageing Dev 2001; 122: 1169-86.

[388] Medicherla R, Leers-Sucheta S, Lua Y, Azhar S. Age-dependent modulation of NF- $\kappa \mathrm{B}$ expression in rat adrenal gland. Mech Ageing Dev 2002; 123: 1211-27.

[389] Angel P, Karin M. The role of Jun, Fos and the AP-1 complex in cell-proliferation and transformation. Biochim Biophys Acta 1991; 1072: 129-57.

[390] Chinenov Y, Kerppola TK. Close encounters of many kinds: FosJun interactions that mediate transcription regulatory specificity. Oncogene 2001; 20: 2438-52.

[391] Shaulian E, Karin M. AP-1 in cell proliferation and survival. Oncogene 2001; 20: 2390-400.

[392] de Bosscher K, vanden Berghe W, Haegeman G. The interplay between the glucocorticoid receptor and nuclear factor- $\kappa \mathrm{B}$ or acti- 
vator protein-1: molecular mechanisms for gene repression. Endocr Rev 2003; 24: 488-522.

[393] Hess J, Angel P, Schorpp-Kistner M. AP-1 subunits: quarrel and hormony among siblings. J Cell Sci 2004; 117: 5965-73.

[394] Karamouzis MV, Konstantinopoulos PA, Papavassiliou AG. The activator protein-1 transcription factor respiratory epithelium carcinogenesis. Mol Cancer Res 2007; 5: 109-20.

[395] Pennypacker KR, Hong JS, Douglass J, McMiLlian MK. Constitutive expression of AP-1 transcription factors in the rat adrenal. Effects of nicotine. J Biol Chem 1992; 267: 20148-52.

[396] Kimura E, Sonobe MH, Armelin MC, Armelin HA. Induction of FOS and Jun proteins by adrenocorticotropin and phorbol ester but not by 3',5'-cyclic adenosine monophosphate derivatives. Mol Endocrinol 1993; 7: 1463-71.

[397] Li X, Hales KH, Watanabe G, Lee RJ, Pestell RG, Hales DB. The effect of tumor necrosis factor-alpha and cAMP on induction of AP-1 activity in MA-10 tumor Leydig cells. Endocrine 1997; 6: 317-24.

[398] Suzuki S, Nagaya T, Suganuma N, Tooda Y, Seo H. Induction of immediate early genes (IEGS) and ref-1 by human chrionic gonadotropin in murine Leydig cell line (MA-10). Biochem Mol Biol Int 1998; 44: 217-24.

[399] Sharma SC, Richards JS. Regulation of AP1 (Jun/Fos) factor expression and activation in ovarian granulosa cells. Relation to JunD and Fra2 to terminal differentiation. J Biol Chem 2000; 275: 33718-28.

[400] Oktay KH, Oktay MH. Immunohistochemical analysis of tyrosine phosphorylation and AP-1 transcription factors c-Jun, JunD, Fos family during early ovarian follicle development in the mouse. Appl Immunohistochem Mol Morphol 2004; 12: 364-9.

[401] Whitmarsh AJ, Davis RJ. Transcription factor AP-1 regulation by mitogen-activated protein kinase signal transduction pathways. J Mol Med 1996; 74: 589-607.

[402] Dalton TP, Shertzer HG, Puga A. Regulation of gene expression by reactive oxygen. Annu Rev Pharmacol Toxicol 1999; 39: 67-101.

[403] Mechta-Grigoriou F, Gerald D, Yaniv M. The mammalian Jun proteins: redundancy and specificity. Oncogene 2001; 20 (19): 2378-89.

[404] Shaulian E, Karin M. AP-1 as a regulator of cell life and death. Nat Cell Biol 2002; 4: E131-6.

[405] Tell G, Quadrifoglio F, Tribelli C, Kelley MR. The many functions of APE1/Ref-1: not only a DNA repair enzyme. Antioxid Redox Signal 2009; 11: 601-20.

[406] Li B, Tournier C, Davis RJ, Flavell RA. Regulation of IL-4 expression by the transcription factor JunB during $\mathrm{T}$ helper cell differentiation. EMBO J 1999; 18: 420-32.

[407] Bakiri L, Lallemand D, Bossy-Wetzel E, Yaniv M. Cell cycledepndent variations in c-Jun and JunB phosphorylation: a role in the control of cyclin D1 expression. EMBO J 2000; 19: 2056-68.

[408] Passegué E, Wagner EF. JunB suppresses cell proliferation by transcriptional activation of $\mathrm{p} 16^{I N K 4 a}$ expression. EMBO J 2000; 19: 2969-79.

[409] Piechaczk M, Farràs R. Regulation and function of JunB in cell proliferation. Biochem Soc Trans 2008; 36: 864-7.

[410] Vartanian R, Masri J, Martin J, et al. AP-1 regulates cyclin D1 and c-Myc transcription in an AKT-dependent manner in response to mTOR inhibition: role of AIP4/Itch-mediated JunB degradation. Mol Cancer Res 2011; 9: 115-30.

[411] Abidi P, Leers-Sucheta S, Cortez Y, Han J, Azhar S. Evidence that age-related changes in p38 MAP kinase contribute to the decreased steroid production by the adrenocortical cells from old rats. Aging Cell 2008; 7: 168-78.

[412] Ashwell JD. The many paths to p38 mitogen-activated protein kinase activation in the immune system. Nat Rev Immunol 2006; 6: 532-40.

[413] Coulthard LR, White DE, Jones DL, McDermott MF, Burchill SA. P38 ${ }^{\mathrm{MAPK}}$ : stress responses from molecular mechanisms to therapeutics. Trends Mol Med 2009; 15: 369-79.

[414] Cuadrado A, Nebreda AR. Mechanisms and functions of p38 MAPK signaling. Biochem J 2010; 429: 403-17.

[415] Cargnello M, Roux PP. Activation and function of the MAPKs and their substrates, the MAPK-activated protein kinases. Microbiol Mol Biol Rev 2011; 75: 50-83.

[416] Abidi P, Zhang H, Zaidi SM, et al. Oxidative stress-stimulated inhibition of adrenal steroidogenesis requires participation of p38 mitogen-activated protein kinase signaling pathway. J Endocrinol 2008; 198:193-207.

[417] Stocco DM. StAR protein and the regulation of steroid hormone biosynthesis. Annu Rev Physiol 2001; 63: 193-213.

[418] Manna PR, Dyson MT, Stoccco DM. Regulation of the steroidogenic acute regulatory protein gene expression: present and future perspectives. Mol Hum Reprod 2009; 15: 321-33.

[419] Rone MB, Fan J, Papadopoulos V. Cholesterol transport in steroid biosynthesis: role of protein-protein interactions and implications in disease states. Biochim Biophys Acta 2009; 1791: 646-58.

[420] Manna PR, Eubank DW, Stocco DM. Assessment of the role of activator protein-1 on the transcription of the steroidogenic acute regulatory protein gene. Mol Endocrinol 2004;18: 558-73.

[421] Giatzakis C, Batarseh A, Dettin L, Papadopoulos V. The role of Ets transcription factors in the basal transcription of the translocator protein (18 kDa). Biochemistry 2007; 46: 4763-74.

[422] Leers-Sucheta S, Stocco DM, Azhar S. Down-regulation of steroidogenic acute regulatory (StAR) protein in rat Leydig cells: Implications for regulation of testosterone production during aging. Mech Ageing Dev 1999; 107: 197-203.

[423] Luo L, Chen H, Zirkin BR. Leydig cell aging: steroidogenic acute regulatory protein (StAR) and cholesterol side chain cleavage enzyme. J Androl 2001; 22: 149-56.

[424] Cully M, Luo L, Yao ZX, Chen H, Papadopoulos V, Zirkin BR. Cholesterol transport, peripheral benzodiazepine receptor, and steroidogenesis in aging Leydig cells. J Androl 2002; 23: 439-47.

[425] Wang X, Shen CL, Dyson MT, et al. Cycolooxygenase-2 regulation of the age-related decline in testosterone biosynthesis. Endocrinology 2005; 146: 4202-8.

[426] Sun Z, Shen W-J, Sucheta S-L, Azhar S. Impact of aging on cholesterol transport protein expression and steroidogenesis in rat testicular Leydig cells. Open Longev Sci 2008; 2: 76-85.

[427] Bose HS, Sugawara T, Strauss JF $3^{\text {rd }}$, Miller WL. The pathophysiology and genetics of congenital lipoid adrenal hyperplasia. N Eng J Med 1996; 335: 870-8.

[428] Caron KM, Soo S-C, Westel WC, Stocco DM, Clark BJ, Parker $\mathrm{KL}$. Targeted disruption of the mouse gene encoding steroidogenic acute regulatory protein provides insights into congenital lipoid adrenal hyperplasia. Proc Natl Acad Sci USA 1997; 94: 11540-5.

[429] Papadopoulos V, Amri H, Li H, Boujrad N, Vidic B, Garnier M. Targeted disruption of the peripheral-type benzodiazepine receptor gene inhibits steroidogenesis in the R2C Leydig tumor cell line. J Biol Chem 1997; 272: 32129-35.

[430] van Eekelen JAM, Rots NY, Sutanto W, de Kloet ER. The effect of aging on stress responsiveness and central corticosteroid receptors in Brown Norway rat. Neurobiol Aging 1991; 13: 159-70.

[431] van Eekelen JAM, Oitzl MS, De Kloet ER. Adrenocortical hyporesponsiveness and glucocorticoid feedback resistance in old male Brown Norway rats. J Gerontol A Biol Sci Med Sci 1995; 50: B839.

[432] Gruenewald DA, Naai MA, Marck BT, Matsumoto AV. Agerelated decrease in hypothalamic gonadotropin-releasing hormone (GnRH) gene expression, but not pituitary responsiveness to GnRH, in the male Brown Norway rat. J Androl 2000; 21: 72-84.

[433] Sencar-Cupović I, Milković S. The development of sex differences in the adrenal morphology and responsiveness in stress of rats from birth to the end of life. Mech Ageing Dev 1976; 5: 1-9.

[434] Landfield PW, Waymire JC, Lynch G. Hippocampal aging and adrenocorticoids: quantitative correlations. Science 1978; 202: 1098-102.

[435] Brett LP, Chong GS, Coyle S, Levine S. The pituitary-adrenal response to novel stimulation and ether stress in young and aged rats. Neurobiol Aging 1983; 4: 133-8.

[436] Sapolsky RM, Krey LC, McEwen BS. The adrenocortical stressresponse in the aged male rat: impairment of recovery from stress. Exp Gerontol 1983; 18: 55-64.

[437] Sapolsky RM, Krey LC, McEwen BS. Glucocorticoid-sensitive hippocampal neurons are involved in terminating the adrenocortical stress response. Proc Natl Acad Sci USA 1984; 81: 6174-7.

[438] Sapolsky RM, Krey LC, McEwen BS. The adrenocortical axis in the aged rat: impaired sensitivity to both fast and delayed feedback inhibition. Neurobiol Aging1986; 7: 331-5.

[439] Sonntag WE, Goliszek AG, Brodish A, Baldridge JC. Diminished diurnal secretion of adrenocorticotropin (ACTH), but not corticos- 
terone, in old male rats: possible relation to increased adrenal sensitivity to ACTH in vivo. Endocrinology 1987; 120: 2308-15.

[440] Lorens SA, Hata N, Handa RJ, et al. Neurochemical, endocrine and immunological responses to stress in young and old Fischer 344 male rats. Neurobiol Aging 1990; 11: 139-50.

[441] Irwin M, Hauger R, Brown M. Central corticotrophin-releasing hormone activates the sympathetic nervous system and reduces immune function: increased responsivity of the aged rat. Endocrinology 1992; 131: 1047-53.

[442] Cizza G, Calogero AE, Brady LS, et al. Male Fischer 344/N rats show a progressive central impairement of the hypothalamicpituitary-adrenal axis with advancing age. Endocrinology 1994; 134: 1611-20.

[443] Hauger RL, Thrivikraman KV, Plotsky PM. Age-related alterations of hypothalamic-pituitary-adrenal axis function in male Fischer 344 rats. Endocrinology 1994; 134: 1528-36.

[444] Morano MI, Vaquez DM, Akil H. The role of the hippocampal mineralocorticoid and glucocorticoid receptors in the hypothalamopituitary-adrenal axis of the aged Fisher rat. Moll Cell Neurosci 1994; 5: 400-12.

[445] Cizza G, Gold PW, Chrousos GW. Aging is associated in the $344 / \mathrm{N}$ Fischer rat with decreased stress responsity of central and peripheral catecholaminergic systems and impairment of the hypothalamic-pituitary-adrenal axis. Ann NY Acad Sci 1995; 771: 491511.

[446] Mastorakos G, Cizza G, Kvetnansky R, et al. Aging and acute stress decrease corticotrophin releasing hormone in the ovary of the Fischer 344/N rat. Life Sci 1995; 56: 1065-71.

[447] Mulchahey JJ, Kasckow JW, Plotsky PM, Hauger RL. Steroidal regulation of portal arginine-Vasopressin levels in aged Fischer 344 rats. Brain Res 1999; 822: 243-5.

[448] Silverstein JH, Beasley J, Mizuno TM, London E, Mobbs CV. Adrenal neuropeptide Y mRNA but not preprokephalin mRNA induction by stress is impaired by aging in Fisher 344 rats. Mech Ageing Dev 1998; 101: 233-43.

[449] Taglialatela G, Robinson R, Gegg M, Perez-Polo JR. Nerve growth factor, central nervous system apoptosis, and adrenocortical activity in aged Fischer-344/Brown Norway F1 hybrid rats. Brain Res Bull 1997; 43: 229-33.

[450] Hebda-Bauer EK, Morano MI, Therrien M. Aging and corticosterone in Fischer-344 X Brown Norway rats. Brain Res 1999; 827: 93-103.

[451] Herman JP, Larson BR, Speert DB, Seasholtz AF. Hypothalamopituitary-adrenocortical dysregulation in aging F344/BrownNorway F1 hybrid rats. Neurobiol Aging 2001; 22: 323-2.

[452] Kasckow JW, Segar TM, Xiao C, et al. Stability of neuroendocrine and behavioral responsiveness in aging Fischer 344/Brown-Norway hybrid rats. Endocrinology 2005; 146: 3105-12.

[453] Kascknow J, Xiao C, Herman JP. Glial glucocorticoid receptors in aged Fischer 344 (F344) and F344/Brown Norway rats. Exp Gerontol 2009; 44: 335-43.

[454] Spencer RL, McEwen BS. Impaired adaptation of the hypothalamic-pituitary-adrenal axis to chronic ethanol stress in aged rats. Neuroendocrinology 1997; 65: 353-9.

[455] Hess GD, Riegel GD. Adrenocortical responsiveness to stress and ACTH in aging rats. J Gerontol 1970; 25: 354-8.

[456] Riegle GD, Hess GD. Chronic and acute dexamethasone suppression of stress activation of the adrenal cortex in young and aged rats. Neuroendocrinology 1972; 9: 175-87.

[457] Riegle GD. Chronic stress effects on adrenocortical responsiveness in young and aged rats. Neuroendocrinology 1973; 11: 1-10.

[458] Meaney MJ, Aitken DH, van Berkel C, Bhatnagar S, Sapolsky RM. Effect of neonatal handling on age-related impairments associated with the hippocampus. Science1988; 239: 766-8.

[459] Meaney MJ, Aitken DH, Sharma S, Viau V. Basal ACTH, corticosterone and corticosterone-binding globulin levels over the diurnal cycle, and age-related changes in hippocampal type I and type II corticosteroid receptor binding capacity in young and aged, handled and nonhandled rats. Neuroendocrinology 1992; 55: 204-2.

[460] Issa AM, Rowe W, Gauthier S, Meaney MJ. Hypothalamicpituitary adrenal activity in aged, cognitively impaired and cognitively unimpaired rats. J Neurosci 1990; 10: 3247-54.

[461] Rakotondrazafy J, Brudieux R. Age-related changes in plasma aldosterone response to exogenous angiotensin II in the rat. Horm Res 1993; 39: 156-60.
[462] Brudieux R, Ait Chaoui A, Rakotondrazafy J. Age-related decreases in plasma adrenocorticotropic hormone, corticosterone, and aldosterone responses to exogenous corticotrophin-releasing hormone in the rat. Gerontology 1995; 41: 308-14.

[463] Ait-Chaoui A, Rakotondrazafy J, Brudieux R. Age-related changes in plasma corticosterone and aldosterone responses to exogenous ACTH in the rat. Horm Res 1995; 43: 181-7.

[464] Bizon JL, Helm KA, Han J-S, et al. Hypothalamic-pituitary-adrenal axis function and cortiocsterone receptor expression in behaviorally characterized young and aged Long-Evans rats. Eur J Neurosci 2001; 14: 1739-51.

[465] Lewis BK, Wexler BC. Serum insulin changes in male rats associated with age and reproductive activity. J Gerontol 1974; 29: 13944.

[466] Britton GW, Rotenberg S, Adelman RC. Impaired regulation of corticosterone levels during fasting in aging rats. Biochem Biophys Res Commun 1975; 64: 184-8.

[467] Tang F, Phillips JG. Some age-related changes in pituitary-adrenal function in the male laboratory rat. J Gerontol 1978; 33: 377-82.

[468] DeKosky ST, Scheff SW, Cotman CW. Elevated Corticosterone levels: a possible cause of reduced axon sprouting in aged animals. Neuroendocrinology 1984; 38: 33-8.

[469] Scaccianoce S, Di Sciullo AD, Angelucci L. Age-related changes in hypothalamo-pituitary-adrenocortical axis activity in the rat Neuroendocrinology 1990; 52: 150-5.

[470] Forman PJ, Perez-Polo JR, Angelucci L, Ramacci MT, Taglialatela G. Effects of acetyl-L-carnitine treatment and stress exposure on the nerve growth factor receptor ( $\left.\mathrm{p} 75^{\mathrm{NGFR}}\right) \mathrm{mRNA}$ level in the central nervous system of aged rats. Prog Neuro-Psychopharmacol Biol Psychiat 1995; 19: 117-33.

[471] Terrazzino S, Perego C, De Luiqi A, De Simoni MG. Interleukin-6, tumor necrosis factor and corticosterone induction by central lipopolysaccharide in aged rats. Life Sci 1997; 61: 695-701.

[472] Núñez MJ, Rivas M, Riveiro P, et al. Effects of nefazodone on voluntary ethanol consumption induced by isolation stress in young and aged rats. Pharmacol Biochem Behav 2002; 73: 689-96.

[473] Lo M-J, Kau M-M, Wang PS. Effect of aging on corticosterone secretion in diestrous rats. J Cell Biochem 2006; 97: 351-8.

[474] Montaron MF, Drapeu E, Dupret D, et al. Lifelong corticosterone level determines age-related decline in neurogenesis and memory. Neurobiol Aging 2006; 27: 645-54.

[475] Korte SM, Buwalda B, Bouws GAH, Koolhaas JM, Maes FW, Bohus B. Conditioned neuroendocrine and cardiovascular stress responsiveness accompanying behavioral passivity and activity in aged and in young rats. Physiol Behav 1992; 51: 815-22.

[476] Yau JL, Morris RG, Seckl JR. Hippocampal corticosteroid receptor mRNA expression and spatial learning in the aged Wistar rat. Brain Res 1994; 657: 59-64.

[477] Mizuno T, Kimura F. Attenuated stress response of hippocampal acetylcholine release and adrenocortical secretion in aged rats. Neurosci Lett 1997; 222: 49-52.

[478] Bazhanova ED, Chernigovskaya EV, Danilova OA. Different pathways of neurohormonal hypothalamic control of the adrenal cortex function in young and old rats. Mech Ageing Dev 2009; 118: 91-102.

[479] Descamps A, Cespuglio R. Influence of aging on the sleep rebound induced by immobilization stress in the rat. Brain Res 2010; 1335: 14-23.

[480] Garrido P, de Blas M, Del Arco A, Segovia G, Mora F. Aging increases basal but not stress-induced levels of corticosterone in the brain of the awakened rat. Neurobiol Aging 2010; 33 (2): 375-82.

[481] Buchanan JB, Sparkman NL, Chen J, Johnson RW. Cognitive and neuroinflammatory consequences of mild repeated stress are exacerbated in aged mice. Psychoneuroendocrinology 2008; 33: 755-65.

[482] Padgett DA, MacCallum RC, Sheridan JF. Stress exacerbates agerelated decrements in the immune response to an experimental influenza viral infection. J Gerontol Biol Sci 1998; 53A: B347-53.

[483] Rosenthal MJ, Morley JE. Corticotropin releasing factor (CRF) and age-related differences in behavior of mice. Neurobiol Aging 1999; 10: 167-71.

[484] de Wazieres B, Harraga S, Spehner V, et al. Effect of an auditory stress on peritoneal and alveolar cells in C57BL/6J male mice. Luminescence 2000; 15: 233-7. 
[485] Park E, Dumas R, Schuller-Levis G, Rabe A. Exposure to alcohol on $\mathrm{E} 9$ raises post-stress corticosterone in mature but not old mice. Neurosci Let 2004; 368: 345-8.

[486] Dalm S, Enthoven L, Meijer OC, et al. Age-related changes in hypothalamic-pituitary-adrenal axis activity of male C57BL/6J mice. Neuroendocrinology 2005; 81: 372-80.

[487] Harris SB, Gunion MW, Rosenthal MJ, Walford RL. Serum glucose, glucose tolerance, corticosterone and free fatty acids during aging in energy restricted mice. Mech Ageing Dev 1994; 73: 20921.

[488] Thurmond JB, Heishman SJ. Effect of catecholamine precursors on stress-induced changes in motor activity, exploration, and brain monoamines in young and aged mice. Behav Neurosci 1984; 98(3): 506-17.

Received: December 22, 2011

Revised: January 29, 2012

Accepted: February 2, 2012

(C) Zaidi et al.; Licensee Bentham Open.

This is an open access article licensed under the terms of the Creative Commons Attribution Non-Commercial License (http://creativecommons.org/licenses/by-nc/3.0/) which permits unrestricted, non-commercial use, distribution and reproduction in any medium, provided the work is properly cited. 